Prepared for the U.S. Department of Energy under Contract DE-AC05-76RL01830

\title{
Radionuclide Concentrations in Terrestrial Vegetation and Soil Samples On and Around the Hanford Site, 1971 Through 2008
}

MA Simmons

TM Poston

BG Fritz

LE Bisping

July 2011

\section{Pacific Northwest}

NATIONAL LABORATORY

Proudly Operated by Battelle Since 1965 


\title{
DISCLAIMER
}

This report was prepared as an account of work sponsored by an agency of the United States Government. Neither the United States Government nor any agency thereof, nor Battelle Memorial Institute, nor any of their employees, makes any warranty, express or implied, or assumes any legal liability or responsibility for the accuracy, completeness, or usefulness of any information, apparatus, product, or process disclosed, or represents that its use would not infringe privately owned rights. Reference herein to any specific commercial product, process, or service by trade name, trademark, manufacturer, or otherwise does not necessarily constitute or imply its endorsement, recommendation, or favoring by the United States Government or any agency thereof, or Battelle Memorial Institute. The views and opinions of authors expressed herein do not necessarily state or reflect those of the United States Government or any agency thereof.

\author{
PACIFIC NORTHWEST NATIONAL LABORATORY \\ operated by \\ BATTELLE \\ for the \\ UNITED STATES DEPARTMENT OF ENERGY \\ under Contract DE-AC05-76RL01830
}

\author{
Printed in the United States of America \\ Available to DOE and DOE contractors from the \\ Office of Scientific and Technical Information, \\ P.O. Box 62, Oak Ridge, TN 37831-0062; \\ ph: (865) 576-8401 \\ fax: $(865) 576-5728$ \\ email: reports@adonis.osti.gov
}

\begin{abstract}
Available to the public from the National Technical Information Service, U.S. Department of Commerce, 5285 Port Royal Rd., Springfield, VA 22161 ph: (800) 553-6847 fax: $(703) 605-6900$ email: orders@ntis.fedworld.gov online ordering: http://www.ntis.gov/ordering.htm
\end{abstract}

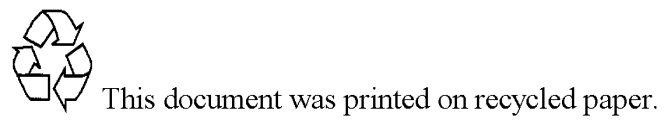




\title{
Radionuclide Concentrations in Terrestrial Vegetation and Soil Samples On and Around the Hanford Site, 1971 Through 2008
}

\author{
MA Simmons \\ TM Poston \\ BG Fritz \\ LE Bisping
}

July 2011

Prepared for

the U.S. Department of Energy

under Contract DE-AC05-76RL01830 



\section{Summary}

Environmental monitoring is conducted on the U.S. Department of Energy (DOE) Hanford Site to comply with DOE Orders and federal and state regulations. Major objectives of the monitoring are to characterize contaminant levels in the environment and to determine site contributions to the contaminant inventory. This report focuses on surface soil and perennial vegetation samples collected between 1971 and 2008 as part of the Pacific Northwest National Laboratory Surface Environmental Surveillance Project performed under contract to DOE. Areas sampled under this program are located on the Hanford Site but outside facility boundaries and on public lands surrounding the Hanford Site. Additional samples were collected during the past 8 years under DOE projects that evaluated parcels of land for radiological release. These data were included because the same sampling methodology and analytical laboratory were used for the projects.

The spatial and temporal trends of six radionuclides collected over a 38-year period were evaluated. The radionuclides - cobalt-60, cesium-137, strontium-90, plutonium-238, plutonium-239/240, and uranium (reported as either uranium-238 or total uranium) - were selected because they persist in the environment and are still being monitored routinely and reported in Hanford Site environmental reports. All these radionuclides were associated with plutonium production and waste management of activities occurring on the site. Other sources include fallout from atmospheric testing of nuclear weapons, which ended in 1980, and the Chernobyl explosion in 1986. Uranium is also a natural component of the soil.

Spatial trends involved comparing data from onsite locations with data from offsite locations. Offsite locations were divided into three categories based on distance from the site. These distance categories were perimeter (which included sites that were on the Hanford Site but away from facilities and reactors, such as sites on Rattlesnake Mountain (i.e., Fitzner/Eberhardt Arid Lands Ecology Reserve) and across the Columbia River); nearby locations (sample sites within 20 miles of the closest site boundary); and distant sites (locations greater than 20 miles from the closest site boundary).

Additional spatial analysis evaluated data collected from the various onsite operational areas. Onsite areas included

- the 100 Areas where the reactors were located along the Columbia River

- 200 Areas on the Central Plateau and the site of much of the fuel reprocessing and waste storage

- 300 Area on the southern edge of the site near the Columbia River where fuel fabrication and testing occurred

- the 400 Area, which was the site of the Fast Flux Test Facility (FFTF)

- the 600 Area, which included open areas between the other industrialized areas, such as the Hanford town site, near the Energy Northwest plant, and FFTF; and two perimeter locations at the Prosser and Yakima barricades.

For temporal analysis, data were compared across decades (1970s, 1980s, 1990s, and 2000s).

Soil and vegetation concentrations of radionuclides were compared to environmental benchmarks and to the contractual minimum detectable concentration (MDC) to evaluate the nature and extent of contamination on and around the Hanford Site. The MDC is based on a number of analytical variables including 
the detection limits of the equipment and pre-analytical sample collection and processing. As a contractual benchmark, the MDC for each radionuclide was set at a concentration well below levels believed to be hazardous to human health and the environment. From this perspective, the MDC can be viewed as an environmental benchmark.

The highest concentrations of each radionuclide generally occurred in the 1970s and 1980s (Table S.1). Observations for each radionuclide are summarized as follows:

- Cobalt-60 is an activation product of reactor operations with a half-life of 5.3 years. More than $80 \%$ of the soil and vegetation samples had concentrations of cobalt- 60 below the minimum detectable amount (MDA); most of the detected values occurred in the 1970s and 1980s. Spatial analysis confirmed that the highest concentrations were from soils and vegetation samples collected onsite near the 100 Areas. Temporally, the percentage of samples with cobalt-60 concentrations above the MDC has decreased from $40 \%$ to $50 \%$ in the 1970 s to less than 5\% today. Additionally, the analysis found that while the mean and median concentration has changed little since the $1980 \mathrm{~s}$, the concentrations for the 95th percentile have decreased since the $1980 \mathrm{~s}$ from 0.05 to $0.0 .02 \mathrm{pCi} / \mathrm{g}$ in the $2000 \mathrm{~s}$ for soil samples. A similar decrease is evident in vegetation samples $(0.119$ to $0.011 \mathrm{pCi} / \mathrm{g})$.

Table S.1. Regions and Decades of the Highest Observed Concentrations of Radionuclides in Surveillance Samples of Soil and Vegetation

\begin{tabular}{|c|c|c|c|c|c|c|}
\hline \multirow[b]{2}{*}{ Constituent } & \multicolumn{2}{|c|}{$\begin{array}{l}\text { Onsite Area with } \\
\text { Highest Mean } \\
\text { Concentration }\end{array}$} & \multicolumn{2}{|c|}{$\begin{array}{c}\text { Percentage of Samples } \\
\text { Above MDC }\end{array}$} & \multicolumn{2}{|c|}{$\begin{array}{l}\text { Decade with Highest } \\
\text { Mean Concentration }\end{array}$} \\
\hline & Soil & Vegetation & Soil & Vegetation & Soil & Vegetation \\
\hline Cobalt- 60 & 100 & 100 & $17 \%$ & $15 \%$ & 1970 & 1970 \\
\hline Cesium-137 & 200 & 200 & $97 \%$ & $58 \%$ & 1980 & 1970 \\
\hline Strontium-90 & 200 & 200 & $82 \%$ & $90 \%$ & 1980 & 1980 \\
\hline Plutonium-238 & 200 & 200 & $55 \%$ & $23 \%$ & 1970 & 1970 \\
\hline Plutonium-239/240 & 200 & 200 & $94 \%$ & $61 \%$ & 1980 & 1970 \\
\hline \multicolumn{7}{|l|}{ Uranium } \\
\hline Total Uranium & 300 & 300 & $100 \%$ & $70 \%$ & 1980 & 1970 \\
\hline Uranium-238 (gamma) & 300 & NA & $17 \%$ & NA & 1980 & NA \\
\hline Uranium-238(alpha-total) $)^{(a)}$ & 300 & 300 & $100 \%$ & $0 \%$ & NA & 2000 \\
\hline 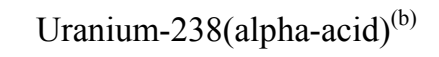 & 300 & NA & $100 \%$ & NA & 2000 & NA \\
\hline \multicolumn{7}{|c|}{$\begin{array}{l}\text { NA = No analyses for this medium. } \\
\text { MDC = Minimum detectable concentration. } \\
\text { (a) Samples collected/analyzed: } 1990-1992 . \\
\text { (b) Samples collected/analyzed: } 1997-2008 .\end{array}$} \\
\hline
\end{tabular}

- Cesium-137 was released to the environment as a result of nuclear fuel processing and from wastes generated by nuclear reactor operations. The half-life for cesium-137 is 30 years. The highest concentrations of cesium-137 were found in soil and vegetation samples near the 200 Area. Soil concentrations were similar over the first two decades (i.e., 1970s and 1980s) and decreased significantly in the 1990s. The decrease continued in the 2000s. The concentration of cesium in vegetation decreased significantly between the 1970s and 2000s; the maximum concentrations 
changed by an order of magnitude each decade between the 1970s and 2000s (i.e., 120, 1.9, 0.16, 0.05 $\mathrm{pCi} / \mathrm{g}$ dry weight). Decreases are a result of radiological decay, a cessation of atmospheric input from weapons testing fallout, and the affinity for cesium-137 to be retained in the upper soil horizons.

More than $95 \%$ of all the soil samples have concentrations of cesium-137 above the MDC, while $58 \%$ of the vegetation samples were above the MDC.

- Strontium-90 was a major component of spent nuclear fuel and the wastes associated with fuel processing. It has a half-life of 28.8 years and is mobile in the environment. The highest concentrations of strontium in soil and vegetation samples were near the 200 Area. The temporal trend for strontium-90 in soil and vegetation was similar to that of cesium-137 in soil, with significantly higher concentrations in the 1970s and 1980s followed by lower values in the 1990s and 2000s.

Strontium-90 concentrations in soil and vegetation were almost all above the MDC until the 2000s, when that dropped to $41 \%$ for soil samples and $4 \%$ for vegetation samples. The observed changes are attributed to radiological decay coupled with a greater propensity for strontium-90 to migrate into deeper soil horizons and a cessation of atmospheric inputs from atmospheric fallout. An increase in the MDC from 0.005 to $0.05 \mathrm{pCi} / \mathrm{g}$ also has influenced this statistic for samples collected in the 2000s.

- Plutonium-238 is a manmade isotope. It has a half-life of 86.4 years and is strongly bound to soil and generally immobile. Sources of plutonium-238 include inadvertent releases at production facilities in the 200 Area. Fifty-five percent of the soil samples had concentrations of plutonium-238 above the contractual MDC, while only $23 \%$ of the vegetation samples had concentration above the MDC. Concentrations of plutonium-238 in soil and vegetation were highest in samples near the 200 Area. Concentrations in both soil and vegetation have decreased since the 1970s.

- Two other isotopes of plutonium (plutonium-239 and plutonium-240) have similar alpha particle energy peaks, and results are typically reported as the sum of both isotopes. The half-life of plutonium-239 is 24,400 years, while the half-life for plutonium-240 is 6,500 years. Sources for plutonium-239/240 are the same as for plutonium-238, and both are immobile and strongly absorbed onto soil particles. More than $90 \%$ of the soil samples had concentrations above the MDC, while slightly more than $50 \%$ of the vegetation samples had concentrations above the MDC. Concentrations showed a significant spatial distribution; soil and vegetation samples near the 200 Area had the highest concentrations. Soil concentrations were the highest in the 1980s and appear to have stabilized with a slight decrease in monitored concentrations. Plutonium-239/240 concentrations in vegetation have decreased since the 1970 s and also appear to have stabilized.

- Uranium, a naturally occurring element, was processed at the Hanford Site to provide reactor fuel. The primary isotope of uranium is uranium-238, which represents $99 \%$ of the isotopic abundance of natural uranium and has a half-life of 4,510,000,000 years. Uranium is mobile in the environment. The analysis of uranium was complicated by the use of several different methods to process and analyze the samples over the nearly 40 years of monitoring. Soil samples collected from 1973 through 1987 were analyzed for total uranium. Starting in 1987, sample results were reported for the three natural isotopes of uranium, focusing on uranium-238. Two analytical methods and two processing methods were used on soil samples, while all vegetation samples were analyzed using a single method for isotopic analysis. Spatially, uranium concentrations in soil and vegetation samples were generally higher in samples collected near the 300 Area compared to other areas. Temporally, soil concentrations were higher in the 1980s compared to the 1970s for total uranium. It is difficult to determine long-term trends because of the different analytical methods. For vegetation samples, concentrations decreased significantly in offsite samples, with no trend for onsite locations. The 
temporal trend for uranium-238 was confounded by small sample sizes and only a 10-year sample window. Total uranium concentrations in soil samples were above the MDC, as were uranium-238 concentrations in samples analyzed by alpha spectrometry. Seventy percent of the vegetation samples had total uranium concentrations above the MDC, while none of the samples analyzed for uranium-238 were above the MDC.

This assessment of soil and vegetation data provides important information on the distribution of radionuclides in areas adjacent to industrial areas, established perimeter locations and buffer areas, and more offsite nearby and distant locations. The concentrations reflect a tendency for detection of some radionuclides close to where they were utilized onsite, but as one moves to unindustrialized areas on the site, surrounding buffer areas and perimeter location into the more distant sites, concentrations of these radionuclides approach background and cannot be distinguished from fallout activity. More importantly, concentrations in soil and vegetation samples did not exceed environmental benchmark concentrations, and associated exposure to human and ecological receptors were well below levels that are demonstratively hazardous to human health and the environment. 


\section{Acknowledgments}

The authors express their appreciation to RL Dirkes, JL Downs, and MS Sackschewsky for critical reviews of this report. LE Bisping provided the data from the Hanford Environmental Information System database. JM Thomas was consulted on statistical matters. Soil and vegetation samples were collected over the 38-year study period by numerous radiation control technicians under the supervision of MD Quarders, EW Lusty, SF Conley, and RW Hanf, Jr. Several Pacific Northwest National Laboratory scientists, including KR Price, TM Poston, EJ Antonio, BL Tiller, and BG Fritz, have provided guidance for past soil and vegetation surveillance sampling. AJ Currie served as technical editor, and KR Neiderhiser provided formatting and text processing support. We also thank the U.S. Department of Energy and its predecessor agencies (U.S. Atomic Energy Commission and the Energy Research and Development Administration) for their continued support. 



\section{Acronyms and Abbreviations}

$\begin{array}{ll}\text { ALE } & \text { Fitzner/Eberhardt Arid Lands Ecology Reserve } \\ \text { BCG } & \text { biota concentration guide } \\ \text { DOE } & \text { U.S. Department of Energy } \\ \text { EDE } & \text { effective dose equivalent } \\ \text { FFTF } & \text { Fast Flux Test Facility } \\ \text { GPS } & \text { Global Positioning System } \\ \text { HEIS } & \text { Hanford Environmental Information System } \\ \text { LEPS } & \text { low-energy photon spectrometry } \\ \text { MDA } & \text { minimum detectable amount (determined by analytical performance) } \\ \text { MDC } & \text { contractual minimum detectable concentration (administrative value) } \\ \text { MEI } & \text { maximally exposed individual } \\ \text { PNNL } & \text { Pacific Northwest National Laboratory } \\ \text { RESRAD } & \text { computer model designed to estimate radiation doses and risks from RESidual } \\ & \text { RADioactive materials } \\ \text { RM } & \text { river mile }\end{array}$





\section{Contents}

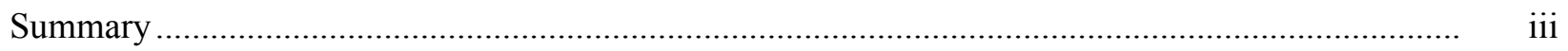

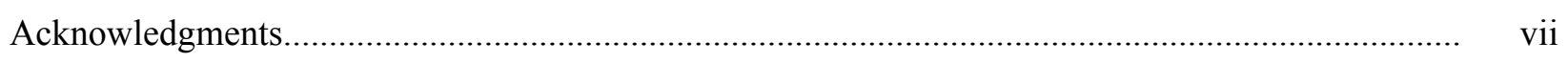

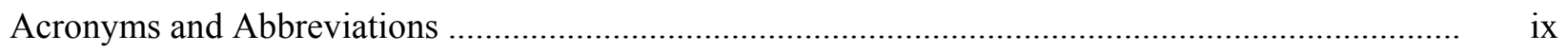

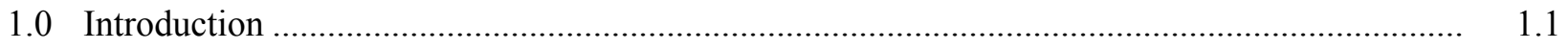

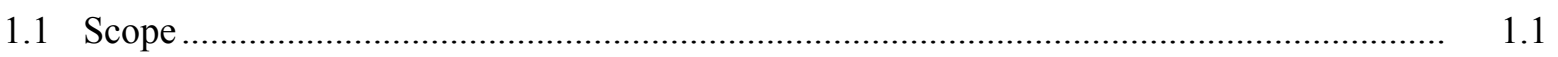

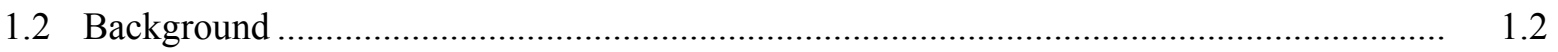

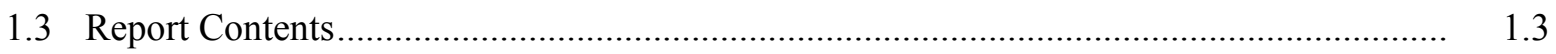

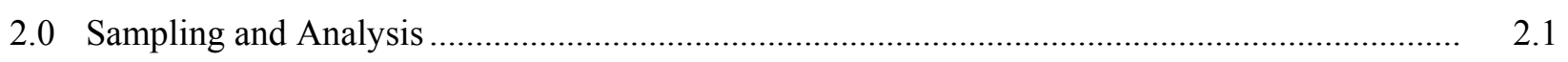

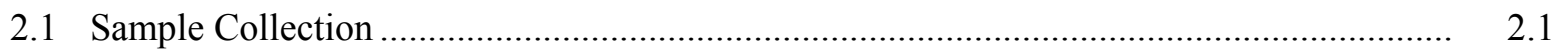

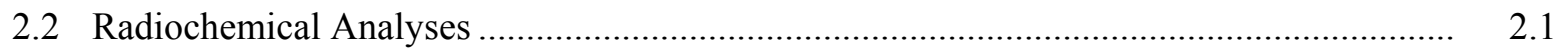

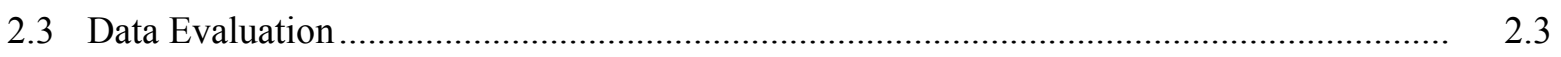

2.4 Site Benchmarks and Guidance Levels ................................................................ 2.10

2.4.1 Minimum Detected Concentrations................................................................. 2.11

2.4.2 Maximally Exposed Individual-Based Administrative Reporting Screens .............. 2.11

2.4.3 Biota Concentration Guidelines ...................................................................... 2.12

2.4.4 Uranium Ecotoxicological Benchmarks......................................................... 2.12

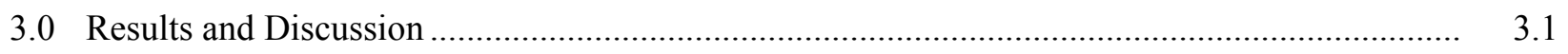

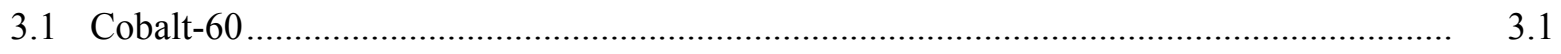

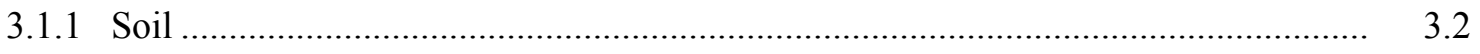

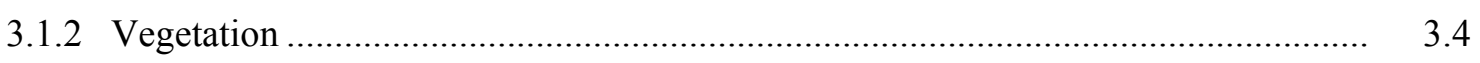

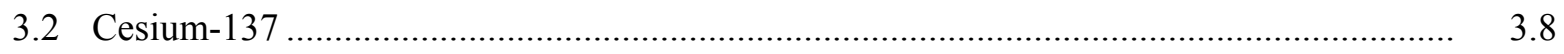

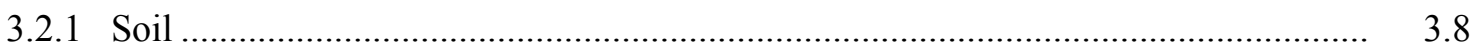

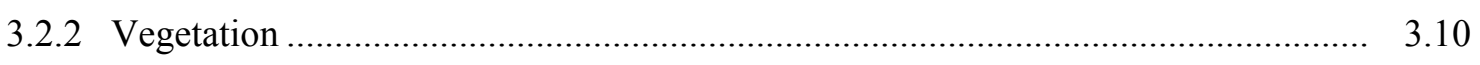

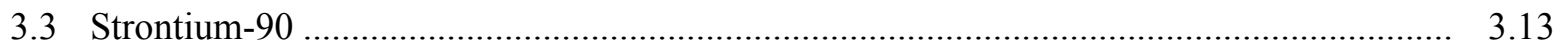

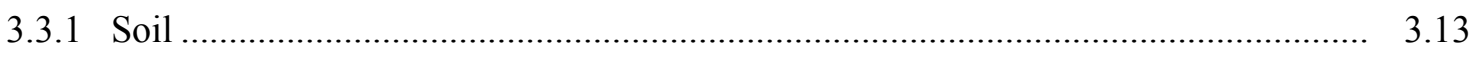

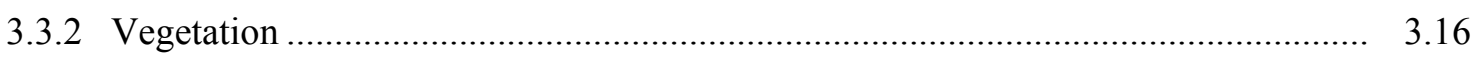

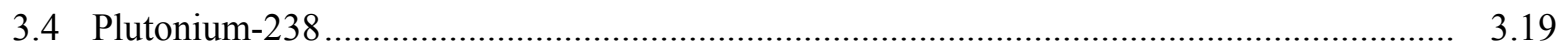

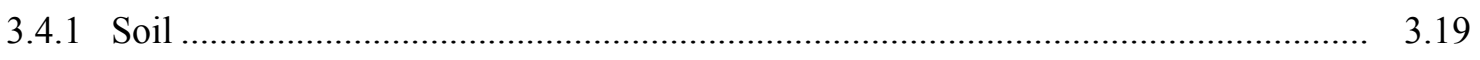

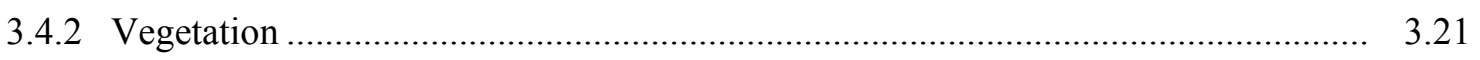

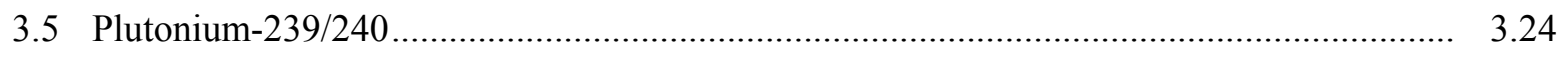

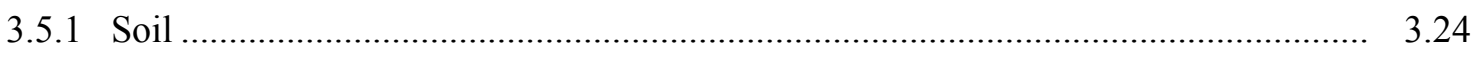

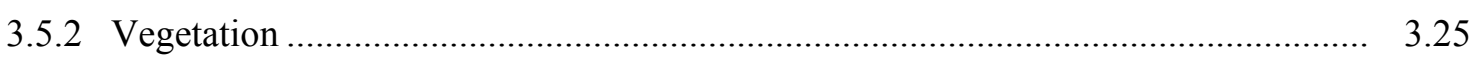

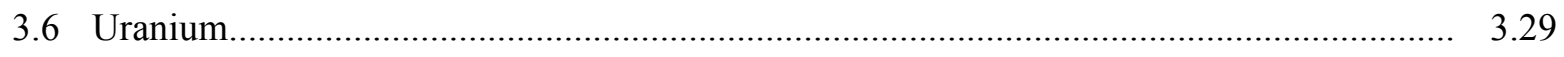

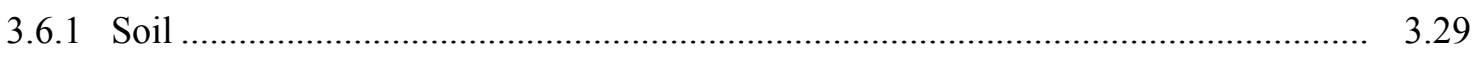

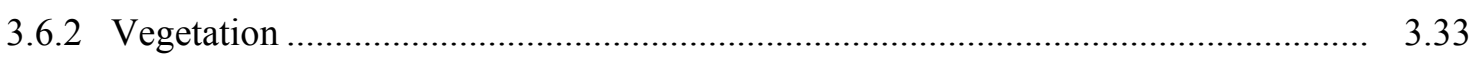

3.7 Site Environmental Benchmarks and Guidance Levels ................................................ 3.38 


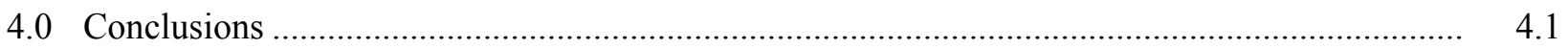

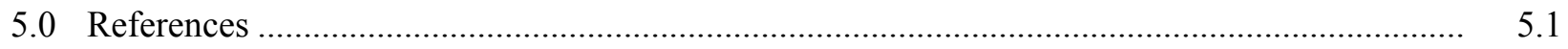

Appendix A - Sample Site Locations ...................................................................................... A.1

Appendix B - Radionuclide Distributions in Soil and Vegetation Samples...................................... B.1

Appendix C - Soil and Vegetation Temporal Trend Analysis ................................................... C.1 


\section{Figures}

2.1 Locations of Onsite, Perimeter, Nearby, and Distant Sample Sites, 2008 ….......................... 2.4

2.2 Concentration Data for Strontium-90 in Soil Samples ....................................................... 2.9

3.1 Median Cobalt-60 Concentrations in Soil Samples Collected from Onsite and Offsite Areas by Decade .

3.2 Cobalt-60 Concentrations in Perennial Vegetation Samples Collected On and Around the Hanford Site Between 1972 and 2008

3.3 Median Cobalt-60 Concentrations in Vegetation Samples Collected from Onsite and Offsite Areas by Decade

3.4 Median Cesium-137 Concentrations in Soil Samples Collected from Onsite and Offsite Areas by Decade.

3.5 Median Cesium-137 Concentrations in Vegetation Samples Collected from Onsite and Offsite Areas by Decade

3.6 Median Strontium-90 Concentrations in Soil Samples Collected from Onsite and Offsite Areas by Decade .

3.7 Median Strontium-90 Concentrations in Vegetation Samples Collected from Onsite and Offsite Areas by Decade.

3.8 Median Plutonium-238 Concentrations in Soil Samples Collected from Onsite and Offsite Areas by Decade

3.9 Median Plutonium-238 Concentrations in Vegetation Samples Collected from Onsite and Offsite Areas by Decade.

3.10 Median Plutonium-239/240 Concentrations in Soil Samples Collected from Onsite and Offsite Areas by Decade.

3.11 Median Plutonium-239/240 Concentrations in Vegetation Samples Collected from Onsite and Offsite Areas by Decade .....

3.12 Uranium and Uranium-238 Concentration in Vegetation Samples Collected at Hanford and Surrounding Locations....

3.13 Median Uranium-238 Concentrations in Vegetation Samples Collected from Onsite and Offsite Areas by Decade. 


\section{Tables}

S.1 Regions and Decades of the Highest Observed Concentrations of Radionuclides

in Surveillance Samples of Soil and Vegetation ................................................................... iv

2.1 Onsite Sample Locations Grouped by Area ......................................................................... 2.5

2.2 Offsite Perimeter Sampling Locations ........................................................................ 2.7

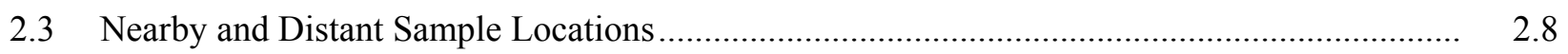

2.4 Definitions for Statistics Presented in Results Tables......................................................... 2.9

2.5 Current Contractual Minimum Detectable Concentration for Radionuclides Evaluated

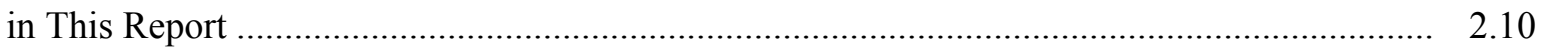

3.1 Cobalt-60 Concentrations in Soil Samples Collected Onsite and at Various Distances

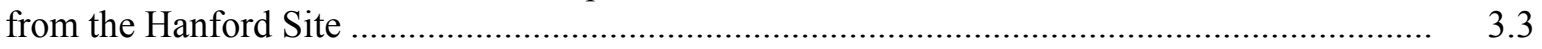

3.2 Cobalt-60 Concentrations in Soil Samples Collected in Different Areas on the Hanford Site

3.3 Cobalt-60 Concentrations in Soil Samples Collected from Areas On and Around the Hanford Site by Decade

3.4 Cobalt-60 Concentrations in Vegetation Samples Collected on the Hanford Site and at Various Distances from the Hanford Site

3.5 Cobalt-60 Concentrations in Vegetation Samples Collected within Different Areas on the Hanford Site

3.6 Cobalt-60 Concentrations in Vegetation Samples Collected On and Around the Hanford Site by Decade

3.7 Cesium-137 Concentration in Soil Samples Collected on the Hanford Site and at Various Distances from the Hanford Site

3.8 Cesium-137 Concentration in Soil Samples Collected from Various Areas on the Hanford Site

3.9 Cesium-137 in Soil Samples Collected from Areas On and Around the Hanford Site by Decade.

3.10 Cesium-137 Concentration in Vegetation Samples Collected on the Hanford Site and at Various Distances from the Hanford Site.

3.11 Cesium-137 Concentration in Vegetation Samples Collected from Various Areas on the Hanford Site

3.12 Cesium-137 Concentrations in Vegetation Samples Collected On and Around the Hanford Site by Decade

3.13 Strontium-90 Concentration in Soil Samples Collected from the Hanford Site and at Various Distances from the Site.

3.14 Strontium-90 Concentrations in Soil Samples Collected from Various Areas on the Hanford Site Between 1971 and 2008

3.15 Strontium-90 Concentrations in Soil Samples Collected on the Hanford Site Between 1971 and 2008 by Decade.

3.16 Strontium-90 Concentration in Vegetation Samples Collected on the Hanford Site and at Various Distances from the Hanford Site. 
3.17 Strontium-90 Concentration in Vegetation Samples Collected from Various Areas on the Hanford Site

3.18 Strontium-90 Concentrations in Vegetation Samples Collected On and Around the Hanford Site by Decade

3.19 Plutonium-238 Concentrations in Soil Samples Collected on the Hanford Site and at Various Distances from the Site Between 1971 and 2008

3.20 Plutonium-238 Concentrations in Soil Samples Collected in Different Areas on the Hanford Site between 1971 and 2008

3.21 Plutonium-238 Concentrations in Soil Samples Collected On and Around the Hanford Site by Decade

3.22 Plutonium-238 Concentrations in Vegetation Samples Collected on the Hanford Site and at Various Distances from the Site Between 1971 and 2008

3.23 Plutonium-238 Concentrations in Vegetation Samples Collected in Different Areas on the Hanford Site Between 1971 and 2008.

3.24 Plutonium-238 Concentrations in Vegetation Samples Collected On and Around the Hanford Site by Decade

3.25 Plutonium-239/240 Concentrations in Soil Samples Collected on the Hanford Site and at Various Distances from the Site Between 1971 and 2008

3.26 Plutonium-239/240 Concentrations in Soil Samples Collected in Different Areas on the Hanford Site Between 1971 and 2008

3.27 Plutonium-239/240 Concentrations in Soil Samples Collected On and Around the Hanford Site by Decade

3.28 Plutonium-239/240 Concentrations in Vegetation Samples Collected on the Hanford Site and at Various Distances from the Site Between 1973 and 2008

3.29 Plutonium-239/240 Concentrations in Vegetation Samples Collected in Different Areas on the Hanford Site Between 1973 and 2008

3.30 Plutonium-239/240 Concentrations in Vegetation Samples Collected On and Around the Hanford Site by Decade

3.31 Total Uranium Concentrations in Soil Samples Collected on the Hanford Site and at Various Distances from the Site Between 1973 and 1987

3.32 Total Uranium Concentrations in Soil Samples Collected from Different Areas on the Hanford Site Between 1973 and 1987

3.33 Uranium Concentrations in Soil Samples Collected On and Around the Hanford Site Between 1970 and 2008 by Decade.

3.34 Uranium-238 Concentrations in Soil Samples Collected on the Hanford Site and at Various Distances from the Site Between 1987 and 2008

3.35 Uranium-238 Concentrations in Soil Samples Collected from Different Areas on the Hanford Site Between 1987 and 2002

3.36 Total Uranium Concentrations in Vegetation Samples Collected on the Hanford Site and at Various Distances from the Site Between 1971 and 1992

3.37 Total Uranium Concentrations in Vegetation Samples Collected from Different Areas on the Hanford Site Between 1971 and 1992.

3.38 Uranium-238 Concentrations in Vegetation Samples Collected on the Hanford Site and at Various Distances from the Site Between 1993 and 2008 
3.39 Uranium-238 Concentrations in Vegetation Samples Collected from Different Areas on the Hanford Site Between 1993 and 2008.

3.40 Uranium Concentrations in Vegetation Samples Collected On and Around the Hanford Site from 1971 Through 2001 by Decade.

3.41 Site Surveillance Screening Criteria for Soils and the Determination of the Soil Exposure Pathway for Protection of the Offsite Human Population and Biota Concentration Guides.

3.42 Comparison of Internal Dose Rates to Plants Based on the 95th Percentile Value by Decade and Location.

3.43 Conversion of 95th Percentile Uranium Soil Concentrations for Comparison to Ecotoxicity Benchmarks. 


\subsection{Introduction}

The Pacific Northwest National Laboratory (PNNL) Surface Environmental Surveillance Project monitors air, surface water and sediment, drinking water, food and farm products, fish and wildlife, soil and terrestrial vegetation, and external radiation for the U.S. Department of Energy (DOE). The purpose of the monitoring is to detect any chemical or radiological contaminant originating from operations, including cleanup, on the DOE Hanford Site in southeastern Washington State. Environmental monitoring of the Hanford Site is conducted to support DOE in demonstrating compliance with numerous federal and state environmental regulations and DOE Orders, specifically DOE Orders 450.1A, 5400.1 Chg 1, and 231.1A. Applicable regulations include the Clean Air Act, Clean Water Act of 1977, Safe Drinking Water Act of 1974, the National Environmental Policy Act of 1969, and Chapters WAC 246-247 (air) and WAC 173-201A (water) for the Washington Administrative Code. As the site mission has changed to restoration and cleanup, a number of land release initiatives were completed that resulted in significant additional soil sampling. The results of these sampling activities have been added to the surveillance soil samples to provide a more robust assessment of radiological soil contaminants.

This report summarizes the results from over 38 years of monitoring soil and native terrestrial vegetation both on the Hanford Site and offsite. Samples were collected to determine radiation levels existing in areas away from production, refinement, and waste management facilities. As such, sample sites were located generally in undisturbed areas on the site and in areas at varying distances from the site. While we identify these geographic areas in standard Hanford notation (e.g., 100 Areas), it is important to remember that the sampling locations for this surveillance program are located outside the facility boundaries and not within the facility boundaries. These onsite locations have also been referred to as far-field samples because they were collected outside established facility boundaries. Waste disposal sites would obviously have higher soil concentrations than the far-field sites, but by monitoring the far-field sites the DOE can better assess the efficacy of its radiological waste management operations on the site. Offsite sampling areas ranged spatially from those adjacent to the site boundary to Moses Lake and Walla Walla. Sample collection efforts emphasized generally downwind locations to the east and northeast of the site. However, samples were collected in all directions from the site because meteorological conditions may carry airborne contaminants in any direction. Over the 38 years of surveillance sampling, changes occurred in the number and location of the sites sampled, in the frequency of sampling, and in the methodology for analyzing the samples. A separate DOE program monitors contamination in effluents and environmental media at or near specific facilities (e.g., Perkins et al. 2005); also see DOE (2008) for additional information on Hanford Site environmental programs. Those data are not included in this summary.

Data used for this report have been published previously in annual Hanford Site environmental reports (e.g., Poston et al. 2010) and in three reviews of soil and vegetation data: 1) for data collected between 1971 and 1976 (Miller et al. 1977), 2) for data collected between 1971 and 1987 (Price 1988), and 3) for data collected between 1983 and 1993 (Poston et al. 1995). Land release data were published in other technical reports (Fritz et al. 2007a, 2007b; Dirkes et al. 2002).

\subsection{Scope}

The purpose of this report is to document spatial and temporal trends in radionuclide concentrations in soil and native vegetation at undisturbed locations on and around the Hanford Site and evaluate the 
potential for impact to human health and the environment by comparison to available environmental benchmarks. Three criteria were used to select the radionuclides for analysis: 1) routinely measured for the past 38 years, 2) measured at both onsite and offsite locations, and 3) characterized by concentrations generally above the detectable limit. Six radionuclides meeting these criteria were selected for evaluation: cobalt-60, cesium-137, strontium-90, uranium (total and uranium-238), plutonium-238, and plutonium 239/240. These radionuclides have short to fairly long half-lives. Other radionuclides associated with Hanford Site operations, such as iodine-129, iodine-131, technetium-99, or americium241, were not sampled extensively and were not evaluated for temporal or spatial relationships in this report. We report major conclusions for each radionuclide regarding spatial and temporal observations. Detailed supporting statistical data are provided for those who desire a more technical and quantitative assessment of the data.

\subsection{Background}

The DOE Hanford Site was established in 1943 in Washington State for nuclear materials production. Between 1944 and 1987, nine reactors were built and operated along the segment of the Columbia River called the Hanford Reach. Support facilities to fabricate fuel for the reactors and to separate and recover plutonium were built at other locations across the site. In 1971, the last of the single-pass reactors was closed, and the last reactor was shut down in January 1987. Other processing and test facilities have also been shut down, and the site is currently undergoing an extensive cleanup process.

Environmental monitoring at the Hanford Site began in 1944 (Noonan and Stapp 2003). Historically, the targets of environmental monitoring included agricultural products, soil, vegetation, air, surface and ground water, wildlife, fish, and other aquatic organisms. During Hanford's early years, vegetation was particularly effective at capturing iodine-131. The monitoring activities identified and quantified the contaminant contributions from Hanford Site operations. The routine collection of soil and native terrestrial vegetation samples onsite and offsite began in 1971 (Price and Rickard 1997). Earlier sampling efforts varied in frequency and location and, for vegetation samples, the species sampled (Junkins et al. 1960; Price and Rickard 1997). The objective of these programs was not so much to characterize the distribution of radiological contaminants but to provide measurements of whether or not releases of these contaminants had accumulated in the environment. As such, sampling locations were selected generally downwind of facilities that had the potential for atmospheric releases. Sampling locations off the site were established at varying distances to monitor the spread of contamination. This sample design introduces a bias that needs to be recognized when assessing the surveillance data; that is, the locations are not random, which is the basis for statistical analysis. The non-random selection of sample locations and the varying frequency of sample collection impinge on the robustness of the statistical characterization. In contrast, the land release sampling was performed to characterize the distribution of radionuclides in soil on prescribed tracts of land and is robust for that purpose.

The primary source of radioactive contamination for soil and vegetation samples collected under the surveillance program at the Hanford Site is airborne deposition. Historic sources of airborne radioactivity included releases from onsite operations that occurred in four areas: 100, 200, 300, and 400 Areas (Figure 2.1). The 100 Areas housed the nine plutonium production reactors and are situated along the Columbia River from river mile (RM) 369 to RM 385. Numerous short-lived activation products and minor amounts of fission products were released during operation of these reactors. Fuel processing and waste management occurred in the 200 Areas on the Hanford Central Plateau. Airborne releases from the 
200 Area initially included large amounts of radioiodine (1940s-1950s) that were later reduced by holding irradiated fuel to allow for decay of radioiodine before processing. As waste and effluent management technology improved, the airborne effluents contained smaller amounts of other fission products and plutonium. Research and reactor fuel fabrication with uranium took place in the 300 Area along the southern boundary of the Hanford Site bordered on the east by the Columbia River. Uranium is currently a major focus of ongoing cleanup in the 300 Area. The Fast Flux Test Facility (FFTF) occupied the 400 Area, located northwest of the 300 Area, and began operations in 1980 and last operated in 1992.

Other sources for radionuclides found in soil and vegetation samples are fallout from atmospheric weapons testing conducted during the 1950s through the 1980s (Perkins and Thomas 1980). In addition, the Chernobyl accident in 1986 resulted in the dispersal of measurable amounts of radioactivity that appeared in environmental media sampled at the Hanford Site in 1986 (Price 1987; Woodruff 1987).

The shift in 1990 from nuclear materials production to environmental restoration at the Hanford Site has focused attention on potential environmental contamination on and around the site from secondary source terms associated with suspension and dispersion of fugitive dust. Waste site cleanup operations employ dust suppression measures, but fugitive dust from site cleanup and non-point source releases represent a vector for potential transport of site contaminants around and possibly off the site. Fugitive dust was of special concern after the wildfire in 2000 that burned a large portion of the Hanford Site and left large areas denuded of vegetation and subject to wind dispersion (Cadwell and Poston 2001; Albin and Jaquish 2002).

\subsection{Report Contents}

Chapter 2 presents the methods used to collect, process, and analyze soil and vegetation samples. The chapter also discusses the statistical methods employed to evaluate the spatial and temporal trends. Results are presented for each radionuclide for both soil and vegetation samples in Chapter 3. Sampling conducted under the environmental surveillance program is identified as routine sampling. Report summary and conclusions for each radionuclide are in Chapter 4. References are in Chapter 5. Appendices A, B, and C contain supporting graphs, figures, and analyses. 



\subsection{Sampling and Analysis}

Soil and native vegetation data for this report were collected between 1971 and 2008 and analyzed for concentrations of cobalt- 60 , cesium-137, strontium-90, uranium-238, plutonium-238, and plutonium239/240. This section discusses the procedures for sample collection and methods used for radiochemical and statistical analyses of soil and vegetation data.

\subsection{Sample Collection}

All sample sites for soil and vegetation surveillance sampling were located in undeveloped shrubsteppe areas. When routine sampling first began, soil and vegetation samples were collected at the same location. In the mid-1990s, sampling objectives were reprioritized (Dirkes and Hanf 1996), interrupting the yearly sampling scheme and placing some sample sites on a triennial schedule. In 1993, vegetation sampling was discontinued at some of the sample locations due to reduced budget. Routine sample locations are documented annually in the Hanford Site Environmental Surveillance Master Sampling Schedule (e.g., Bisping 2006). In addition to routine sampling, soil and vegetation samples were collected as part of special-purpose studies. These studies (including the land release studies), utilized the same collection and analysis procedures as the routine sampling and were included in this assessment where appropriate.

Sample collection procedures for soil have not changed since 1971 (Price and Rickard 1997) and were documented in Hanf et al. (2007). A soil sample consists of five separate plugs, $2.5 \mathrm{~cm}$ (1 in.) deep and $10 \mathrm{~cm}$ (4 in.) in diameter, taken from an area of about $100 \mathrm{~m}^{2}$. Soil samples may have large pieces of vegetation, rocks, and other debris that were removed when the sample was collected. Generally, one composite sample was collected from each location except for occasional duplicate samples collected for quality control. On occasion, co-sampling was conducted with the Washington State Department of Health to support independent oversight objectives. This activity involved collecting enough soil (10 plugs) to process with a riffle splitter. PNNL and the Washington State Department of Health then analyzed the split samples for the same radionuclides. The Washington State Department of Health is responsible for publishing its results (e.g., Van Verst and Albin 2002).

Vegetation samples were collected from big sagebrush (Artemisia tridentata), green rabbitbrush (Chrysothamnus viscidiflorus), or gray rabbitbrush (Ericameria nauseosa) because their foliage was less likely to be contaminated from soil during collection. Samples were clipped from the current year's growth, with the amount from each shrub species in proportion to their relative abundance at each site. During some of the early years, if shrubs were not present at a site, grasses or forbs were sampled. However, this practice was discontinued in the early 1990s because of potential differences in the ability of different species of plants to transfer radionuclides from the soil to the leaves and stems, and a few locations without shrubs were discontinued. Data from both routinely collected and special-study vegetation samples are included in this report.

\subsection{Radiochemical Analyses}

The specifics of the analytical procedures have changed over the years, but, except for uranium, these procedures produced concentrations that were comparable. Samples collected from 1971 through 2007 
were analyzed by a contract laboratory in Richland, Washington. Prior to 1990, US Testing operated the facility. After 1990, this operation was sold multiple times and has been operated by International Technology; Quanterra, Inc.; Severn Trent, Inc.; and Test America, Inc. In 2008, analytical services for soil and vegetation samples were provided by GEL Laboratories, Charleston, South Carolina.

The composited soil samples were dried at $105^{\circ} \mathrm{C}$ and passed through a 2-mm sieve prior to radionuclide analysis. The gamma-emitting isotopes (cobalt-60 and cesium-137) were measured by direct counting using either a germanium or a sodium-iodide detector. The sodium-iodide crystal technology was used only on vegetation samples prior to 1975 . The procedures for measuring strontium-90 and the plutonium isotopes involved multiple steps including drying, leaching with nitric acid and/or hydrochloric acid, and precipitation or electro deposition on a stainless steel disk. A low-background, gas-flow proportional counter was used to measure strontium-90, while alpha spectroscopy was used to count plutonium isotopes.

Three methods were used to analyze uranium in soil. Fluorometry was used until 1987 and measured total uranium concentration. Sample processing involved sieving the sample, ashing the samples in a furnace, and acid leaching of the uranium from the soil residue. The leached uranium was extracted as a tetrapropyl ammonium uranyl trinitrate complex and fused with sodium and lithium fluoride for analysis in the fluorometer.

In 1987, fluorometry was replaced by low-energy photon spectrometry (LEPS), which gave results for uranium-238 as well as uranium-235. This method was used from 1987 through 1989 and in 1992 and 1993. The basic method involves counting of the sieved sample in a special spectrophotometer with no chemical processing of the sample.

Starting in 1990, soil samples were analyzed for isotopes of uranium using alpha spectrometry (Poston et al. 1995). Soils analyzed by alpha spectrometry were processed using two different procedures. From 1990 to 1992, soil samples were dissolved in nitric acid to recover the uranium. This process recovered uranium bound within the soil matrix as well as surface-adsorbed uranium and is designated alpha-total in this report. Starting in 1997, soil samples were acid-leached, a less destructive processing that removed only surface-bound uranium. This method is designated alpha-acid in this report. Thus, the concentration of uranium-238 in soil samples is associated with both the procedure for processing the soil as well as the analysis method. Soil samples analyzed using LEPS had higher concentrations than samples analyzed using alpha spectroscopy and the acid-leach process (1997 to 2008). The concentrations resulting from LEPS were similar to concentrations detected using alpha spectroscopy with total dissolution (1990-1992). Fluorometry results were reported as total uranium (including both uranium-234 and uranium-238) and should be similar to acid leaching results because uranium left in the soil particle matrix is not analyzed. In this report, we have focused on uranium-238, so the fluorometric results should be generally twice the activity levels of uranium-238 reported for acid leaching.

Vegetation samples were dried and milled prior to analysis. Gamma spectroscopy involved the direct counting of 150 to $300 \mathrm{~g}$ of dried and milled plant matter. All radiochemical procedures for strontium-90 and isotopic plutonium analyses used the same processing (drying, ashing, and nitric acid dissolution). Fluorometry was used to measure total uranium from 1971 to 1992 . For the fluorometric analysis, uranium was extracted from the acid leachate as a tetrapropyl ammonium uranyl trinitrate complex and 
fused with lithium fluoride. Alpha spectrometry was then used to measure uranium-238 concentrations between 1990 and 2008.

Radiochemical procedures for analyzing soil and vegetation samples were designed to measure radionuclide concentrations at or below the reporting thresholds for the Hanford Site (DOE 1991). Over time, the designation less than detected has been associated with various analytical thresholds. These thresholds included values less than zero, less than the 2-sigma counting error, less than the total 2-sigma analytical error, less than the minimum contractual threshold (e.g., minimum detectable concentration, or MDC), and less than the minimum detectable amount (MDA). The counting error is defined in the Hanford Environmental Information System (HEIS) database as the error value measured by counting disintegrations of radioactive analytes and serves as a lower bound for the measurement uncertainty. The total analytical error is a combination of the counting error plus laboratory errors propagated during the analysis, and is reported as a 2-sigma value. The MDC is a threshold concentration contractually established to meet the programmatic and technical objectives of the monitoring program. Over the years, the MDC has changed as analytical methods have improved. Consequently, the MDC is used in this summary report simply as a benchmark for general detectability and as an impact benchmark. In comparison, the MDA is the actual minimum concentration achieved by the laboratory for a specific analysis and may actually be lower than the MDC for specific batches of samples. The MDA provides an indication of the sensitivity of the analytical method and has been routinely recorded in HEIS since 1998. Results that fall below the MDA are flagged with " $U$ " in the database as below detection and have been quantified in the summary data tables.

\subsection{Data Evaluation}

We analyzed radionuclide concentration data from soil and vegetation samples to evaluate spatial and temporal trends. To evaluate spatial trends, sample sites were assigned to categories based on their distance from radiological sources on the site. Samples were first categorized as either onsite or offsite. Current onsite sample locations were near sources of radiological releases in operation in 1971 and were located on the Hanford Site proper, within the area bounded by the Columbia River on the north and east and by Highways 240 and 24 on the west (Figure 2.1 and Table 2.1). Onsite locations were further classified by area: 100, 200, 300, 400,600, and perimeter (Figure 2.1). More detailed maps showing the location of all historic soil and vegetation sampling sites are found in Appendix A. The 400 Area is associated with the FFTF, while the 600 Area contains undeveloped areas excluding the Fitzner/Eberhardt Arid Lands Ecology (ALE) Reserve and the North Slope area. There were two perimeter onsite locations - the Prosser and Yakima Barricades. Offsite samples included samples collected at locations at greater distances from radiological release sources. There were three categories of offsite samples: perimeter, nearby, and distant. Perimeter samples were from locations both onsite and offsite (Table 2.2). Nearby locations included local population centers surrounding the site (Table 2.3). Finally, distant locations were chosen to serve as background for comparison (Table 2.3). These categories are similar to the designations for air sample sites established in the Surface Environmental Surveillance Project (Figure 2.1).

The inclusion of additional soil samples from the land release studies to the data set added a considerable number of samples from perimeter areas that have the potential to influence results within that decade. To test for any potential effect, the results from soil analyses collected under the surveillance 


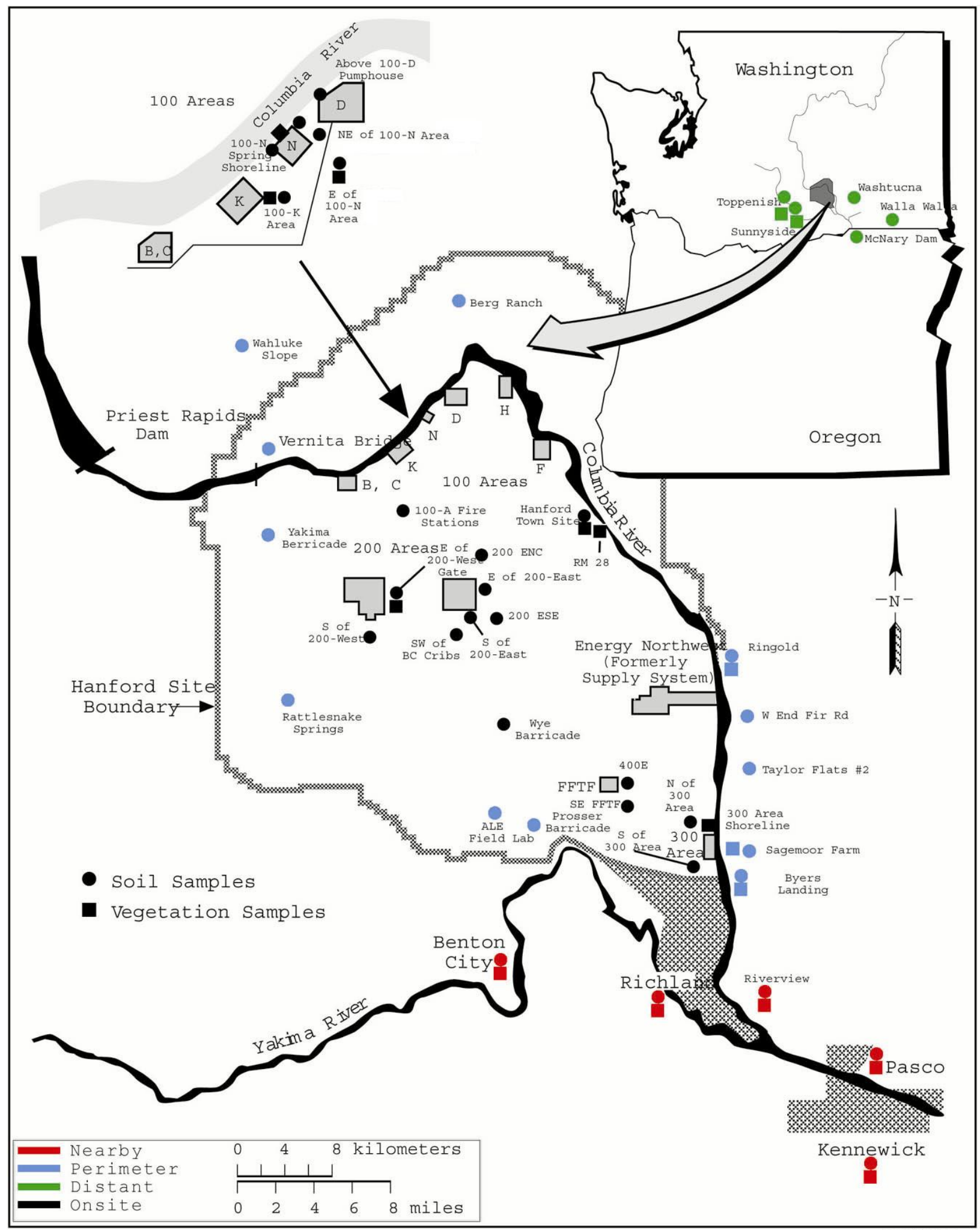

G02020072.4

Figure 2.1. Locations of Onsite, Perimeter, Nearby, and Distant Sample Sites, 2008. Appendix A shows the locations of current and past sampling sites. 
Table 2.1. Onsite Sample Locations Grouped by Area

\begin{tabular}{|c|c|c|c|c|}
\hline Area & Sample Site Name ${ }^{(a)}$ & Soil & Vegetation & $\begin{array}{l}\text { Appendix } \\
\text { Figure }\end{array}$ \\
\hline \multirow[t]{10}{*}{100 Area } & 100 AREA FIRE STAT & $\mathrm{x}$ & $\mathrm{x}$ & A. 2 \\
\hline & 100 F CP 58 & $\mathrm{x}$ & $\mathrm{x}$ & A. 2 \\
\hline & $100 \mathrm{~K}$ AREA & $\mathrm{x}$ & $\mathrm{x}$ & A. 2 \\
\hline & 100N SHORE ABOVE HGP & $\mathrm{x}$ & & A. 2 \\
\hline & 100N SPRING SHORELIN & $\mathrm{x}$ & $\mathrm{x}$ & A. 2 \\
\hline & NE OF 100 N AREA & $\mathrm{x}$ & $\mathrm{x}$ & A. 2 \\
\hline & NE CORNER 100 N AREA & $\mathrm{x}$ & $\mathrm{x}$ & A. 2 \\
\hline & E OF 100 N AREA & $\mathrm{x}$ & $\mathrm{x}$ & A. 2 \\
\hline & SE OF 100N TRENCH & $\mathrm{x}$ & $\mathrm{x}$ & A. 2 \\
\hline & ABOVE 100D PUMPHOUSE & $\mathrm{x}$ & & A. 2 \\
\hline \multirow[t]{11}{*}{200 Area } & 200 AREA FIRE STAT & $\mathrm{x}$ & $\mathrm{x}$ & A. 3 \\
\hline & $200 \mathrm{ENC}$ & $\mathrm{x}$ & $\mathrm{x}$ & A. 3 \\
\hline & 200 E AREA CP 59 & $\mathrm{x}$ & $\mathrm{x}$ & A. 3 \\
\hline & $200 \mathrm{ESE}$ & $\mathrm{x}$ & $\mathrm{x}$ & A. 3 \\
\hline & S OF $200 \mathrm{E}$ & $\mathrm{x}$ & $\mathrm{x}$ & A. 3 \\
\hline & E OF $200 \mathrm{E}$ & $\mathrm{x}$ & $\mathrm{x}$ & A. 3 \\
\hline & SW OF B/C CRIBS & $\mathrm{x}$ & $\mathrm{x}$ & A. 3 \\
\hline & E SIDE US ECOLOGY BG & $\mathrm{x}$ & $\mathrm{x}$ & A.3 \\
\hline & $200 \mathrm{~W}$ AREA CP 60 & $\mathrm{x}$ & $\mathrm{x}$ & A. 3 \\
\hline & S OF $200 \mathrm{~W}$ & $\mathrm{x}$ & $\mathrm{x}$ & A. 3 \\
\hline & E OF 200 W GATE & $\mathrm{x}$ & $\mathrm{x}$ & A. 3 \\
\hline \multirow[t]{17}{*}{300 Area } & ISLAND 340-RICH-RIV & $\mathrm{x}$ & $\mathrm{x}$ & A9 \\
\hline & SOUTH 300 AREA & $\mathrm{x}$ & $\mathrm{x}$ & A. 4 \\
\hline & 300 SOUTH GATE & $\mathrm{x}$ & $\mathrm{x}$ & A. 4 \\
\hline & 331 BLDG. CP 50 & $\mathrm{x}$ & $\mathrm{x}$ & A. 4 \\
\hline & N CENTER 300 FENCE & $\mathrm{x}$ & $\mathrm{x}$ & A. 4 \\
\hline & W. 300 AREA CLEANUP & $\mathrm{x}$ & $\mathrm{x}$ & A. 4 \\
\hline & 300 AREA SHORELINE & & $\mathrm{x}$ & A. 4 \\
\hline & NORTH 300 AREA & $\mathrm{x}$ & $\mathrm{x}$ & A. 4 \\
\hline & N. 300 AREA CLEANUP SITE & $\mathrm{x}$ & $\mathrm{x}$ & A. 4 \\
\hline & $400 \mathrm{E}$ & $\mathrm{x}$ & $\mathrm{x}$ & A.1 \\
\hline & SE SIDE OF FFTF & $\mathrm{x}$ & $\mathrm{x}$ & A.1 \\
\hline & 4S-ARMY LOOP INTER & $\mathrm{x}$ & $\mathrm{x}$ & A.1 \\
\hline & ARMY LOOP ROAD CP 40 & $\mathrm{x}$ & $\mathrm{x}$ & A.1 \\
\hline & ENERGY NW-1 - NW-10 $0^{(\mathrm{b})}$ & $\mathrm{x}$ & & A. 5 \\
\hline & FFTF CP 62 & $\mathrm{x}$ & $\mathrm{x}$ & A.1 \\
\hline & GABLE POND CP 43 & $\mathrm{x}$ & $\mathrm{x}$ & A.1 \\
\hline & HANFORD SLOUGH & & $\mathrm{x}$ & A. 1 \\
\hline
\end{tabular}


Table 2.1. (contd)

\begin{tabular}{|c|c|c|c|c|}
\hline Area & Sample Site Name ${ }^{(a)}$ & Soil & Vegetation & $\begin{array}{c}\text { Appendix } \\
\text { Figure }\end{array}$ \\
\hline \multirow[t]{2}{*}{400 Area } & HANFORD TOWNSITE & $\mathrm{x}$ & $\mathrm{x}$ & A. 1 \\
\hline & HANFORD TOWNSITE-RIV & $\mathrm{x}$ & $\mathrm{x}$ & A. 1 \\
\hline \multirow[t]{4}{*}{600 Area } & HANFRD TWNSITE HRM28 & & $\mathrm{x}$ & A. 1 \\
\hline & N 1 MI. WPPSS NO. 2 & $\mathrm{x}$ & $\mathrm{x}$ & A. 1 \\
\hline & S 1 MI. WPPSS NO. 2 & $\mathrm{x}$ & $\mathrm{x}$ & A. 1 \\
\hline & WYE BARRICADE & $\mathrm{x}$ & $\mathrm{x}$ & A. 1 \\
\hline \multirow[t]{2}{*}{ Perimeter } & PROSSER BARRICADE & $\mathrm{x}$ & $\mathrm{x}$ & A. 1 \\
\hline & YAKIMA BARRICADE & $\mathrm{x}$ & $\mathrm{x}$ & A. 1 \\
\hline
\end{tabular}

(a) Site names from the Hanford Environmental Information System database.

(b) Collected as part of a land release study (Dirkes et al. 2002).

project from perimeter locations from 2000 through 2008 were compared to data collected during the land release studies of ALE and the North Slope (Fritz et al. 2007a, 2007b). Statistical software in Microsoft Excel was use to analyze the potential for effects on u-transformed data. An $F$-test was conducted to determine if the variances were different. This was followed by a $t$-test if the variances were different under an assumption of unequal variances. If the $F$-test was insignificant, then a $t$-test was performed under an assumption of equal variance.

To analyze for temporal trends, the study period was divided into decades (1971-1979, 1980-1989, 1990-1999, 2000-2008). The last decade (2000) contained three discrete years of routine soil and vegetation surveillance data and the soil data from the land release studies. Sampling efforts have changed over the 38 years as the site mission and operations have changed. The result is unequal sampling effort, both temporally and spatially, over the study period.

Radionuclide concentration data generally are log-normally distributed with many small values and few high ones (Figure 2.2) (Eberhardt and Gilbert 1980). In addition, radiological counting can result in valid "negative concentrations" when background counts randomly exceed sample counts. To analyze the data using parametric statistics requires transforming the data and adding a constant to the values to remove negative concentrations. This makes interpretation and presentation of the data complex and less intuitive; therefore, non parametric statistical tests were used (Gilbert 1987).

Descriptive statistics (Table 2.4) were used to summarize radionuclide concentrations by spatial categories and by decade. Statistics included the mean, median, standard deviation, minimum, maximum, the 25th and 75th percentiles, 95th percentile, and the number of samples. If the data are normally distributed, the mean and median will be similar. However, in those cases where the data are not normally distributed, the median is a better indicator of the central tendency of the distribution (Gotelli and Ellison 2004) (see Figure 2.2 for an example). In addition, a mean much higher than the median indicates the presence of one or more high concentrations that are skewing the distribution. Using both the mean and the median as measures of central tendency provides more information about the distribution of the data. 
Table 2.2. Offsite Perimeter Sampling Locations

\begin{tabular}{|c|c|c|c|}
\hline Sample Site Name ${ }^{(a)}$ & Soil & Vegetation & Figure \\
\hline ALE $1-9^{(\mathrm{b})}$ & $\mathrm{x}$ & & A. 6 \\
\hline ALE E1-E15 $5^{(b)}$ & $\mathrm{x}$ & & A. 6 \\
\hline ALE FIELD LAB (ERC) & $\mathrm{x}$ & $\mathrm{x}$ & A.1 \\
\hline ALE HQ Lysimeter $1-5^{(\mathrm{b})}$ & $\mathrm{x}$ & & A. 6 \\
\hline ALE W1-W16 ${ }^{(b)}$ & $\mathrm{x}$ & & A. 6 \\
\hline BYERS LANDING & $\mathrm{x}$ & $\mathrm{x}$ & A. 4 \\
\hline BYERS LND PUMP HOUSE & $\mathrm{x}$ & $\mathrm{x}$ & A. 4 \\
\hline ERC & $\mathrm{x}$ & $\mathrm{x}$ & A1 \\
\hline GULLY E. OF COL.RIV. RA. & $\mathrm{x}$ & $\mathrm{x}$ & A. 4 \\
\hline HRNM MCG-1 - MCG-199 & $\mathrm{x}$ & & A.7 \\
\hline HRNM NS-1 - NS-48 ${ }^{(\mathrm{b})}$ & $\mathrm{x}$ & & A. 8 \\
\hline N END VERNITA BRIDGE (aka Vernita Bridge) & $\mathrm{x}$ & $\mathrm{x}$ & A.1 \\
\hline NE CORNER EXXON SITE & $\mathrm{x}$ & $\mathrm{x}$ & A.1 \\
\hline NORTH RICHLAND CP 56 & $\mathrm{x}$ & $\mathrm{x}$ & A. 4 \\
\hline PETTETT FARM & $\mathrm{x}$ & $\mathrm{x}$ & A.9 \\
\hline POTHOLES CANAL RD/COL.RIV. RA. INTERSECT & $\mathrm{x}$ & $\mathrm{x}$ & A. 4 \\
\hline RATTLESNAKE SPRINGS & $\mathrm{x}$ & $\mathrm{x}$ & A.1 \\
\hline RINGOLD AREA & $\mathrm{x}$ & $\mathrm{x}$ & A.9 \\
\hline RIVERSHORE ROAD & $\mathrm{x}$ & $\mathrm{x}$ & A. 4 \\
\hline RIVRVIEW-HARRIS & $\mathrm{x}$ & $\mathrm{x}$ & A.9 \\
\hline RT. 240 CP 54 & $\mathrm{x}$ & $\mathrm{x}$ & A.1 \\
\hline SAGEMOOR FARM & $\mathrm{x}$ & $\mathrm{x}$ & A.9 \\
\hline SAGEMOOR SPUR/COL.RIV. RD INTERSECTION & $\mathrm{x}$ & $\mathrm{x}$ & A. 4 \\
\hline SNIVELY Lysimeter $1-5^{(\mathrm{b})}$ & $\mathrm{x}$ & & A. 6 \\
\hline TAYLOR FLATS NO. 1 & $\mathrm{x}$ & $\mathrm{x}$ & A. 4 \\
\hline TAYLOR FLATS NO. 2 & $\mathrm{x}$ & $\mathrm{x}$ & A. 4 \\
\hline W END OF FIR ROAD & $\mathrm{x}$ & $\mathrm{x}$ & A.9 \\
\hline WAHLUKE OPP 100N & $\mathrm{x}$ & $\mathrm{x}$ & A.9 \\
\hline WAHLUKE SLOPE & $\mathrm{x}$ & $\mathrm{x}$ & A.9 \\
\hline WSU & $\mathrm{x}$ & $\mathrm{x}$ & A. 4 \\
\hline
\end{tabular}

(a) Site names from the Hanford Environmental Information System database.

(b) Collected as part of a land release study (Fritz et al. 2007a, 2007b). 
Table 2.3. Nearby and Distant Sample Locations

\begin{tabular}{|c|c|c|c|c|}
\hline Category & Sample Site Name ${ }^{(a)}$ & Soil & Vegetation & $\begin{array}{l}\text { Appendix } \\
\text { Figure }\end{array}$ \\
\hline \multirow[t]{16}{*}{ Nearby } & BASIN CITY & $\mathrm{x}$ & $\mathrm{x}$ & A.9 \\
\hline & BAXTER SUBSTATION & $\mathrm{x}$ & $\mathrm{x}$ & A. 9 \\
\hline & BENTON CITY & $\mathrm{x}$ & $\mathrm{x}$ & A.9 \\
\hline & BERG RANCH & $\mathrm{x}$ & $\mathrm{x}$ & A.9 \\
\hline & BROADMOOR, PASCO & $\mathrm{x}$ & $\mathrm{x}$ & A.9 \\
\hline & CONNELL & $\mathrm{x}$ & $\mathrm{x}$ & A.9 \\
\hline & COOKE BROS & $\mathrm{x}$ & $\mathrm{x}$ & A.9 \\
\hline & FINLEY RR TRACK & $\mathrm{x}$ & $\mathrm{x}$ & A.9 \\
\hline & KENNEWICK & $\mathrm{x}$ & $\mathrm{x}$ & A. 9 \\
\hline & MESA & $\mathrm{x}$ & $\mathrm{x}$ & A.9 \\
\hline & OTHELLO & $\mathrm{x}$ & $\mathrm{x}$ & A.9 \\
\hline & PASCO & $\mathrm{x}$ & $\mathrm{x}$ & A.9 \\
\hline & PASCO AIRPORT & $\mathrm{x}$ & $\mathrm{x}$ & A. 9 \\
\hline & RIVERVIEW CP 55 & $\mathrm{x}$ & $\mathrm{x}$ & A.9 \\
\hline & TRI-CITY COLISEUM & $\mathrm{x}$ & $\mathrm{x}$ & A.9 \\
\hline & YAKIMA DELTA & $\mathrm{x}$ & $\mathrm{x}$ & A.9 \\
\hline \multirow[t]{9}{*}{ Distant } & GEORGE & $\mathrm{x}$ & $\mathrm{x}$ & A.9 \\
\hline & MC NARY DAM & $\mathrm{x}$ & $\mathrm{x}$ & A.9 \\
\hline & MOSES LAKE AREA & $\mathrm{x}$ & $\mathrm{x}$ & A.9 \\
\hline & SUNNYSIDE & $\mathrm{x}$ & $\mathrm{x}$ & A. 9 \\
\hline & TOPPENISH & $\mathrm{x}$ & $\mathrm{x}$ & A. 9 \\
\hline & WALLA WALLA & $\mathrm{x}$ & $\mathrm{x}$ & A.9 \\
\hline & WANAPUM & $\mathrm{x}$ & $\mathrm{x}$ & A.9 \\
\hline & WASHTUCNA & $\mathrm{x}$ & $\mathrm{x}$ & A.9 \\
\hline & YAKIMA & $\mathrm{x}$ & $\mathrm{x}$ & A. 9 \\
\hline
\end{tabular}

(a) Site names from the Hanford Environmental Information System database.

Additional information about the distribution of the data can be obtained from the minimum, maximum, the standard deviation, and the 25 th and 75 th percentiles (see Figure 2.2 for example). The standard deviation provides an indication of the variability of the data; when it exceeds the mean, it indicates a wide range of values in the data set. The 25 th and 75 th percentiles provide the lower and upper bounds on the central $50 \%$ of the data, with $25 \%$ of the samples having values above the 75 th percentile and $25 \%$ having values less than the 25 th percentile. These percentiles indicate the spread of the data; that is, whether the values are clustered or widely dispersed. The 95 th percentile represents the concentration in which $95 \%$ of the samples have concentrations below this value. It is used for conservatively assessing relative impact of radionuclides in soil and vegetation samples.

In addition to the total number of samples, the number of samples above detection (i.e., the MDA) is reported as samples not carrying the $\mathrm{U}$ (undetected) qualifier. In most samples, the MDA is at or below the contractual MDC. However, there are exceptions, and in some cases where technical problems 
Table 2.4. Definitions for Statistics Presented in Results Tables

\begin{tabular}{|c|c|}
\hline Statistic & Definition \\
\hline Median & $\begin{array}{l}\text { Value for which half the observations, when ranked, lie above and below that value. } \\
\text { When the sample number is even, median is the average of the two middle values. }\end{array}$ \\
\hline Mean & $\begin{array}{l}\text { Measure of central tendency where values are summed and divided by the total number } \\
\text { of samples. }\end{array}$ \\
\hline Standard Deviation & Measure of the variability in the data based on the mean. \\
\hline Minimum & The lowest concentration. \\
\hline Maximum & The highest concentration. \\
\hline 25th Percentile & $\begin{array}{l}\text { The } 25 \text { th percentile where } 25 \% \text { of the sample values are below this value. Used with } \\
75 \text { th percentile to indicate the bounds for } 50 \% \text { of the data. }\end{array}$ \\
\hline 75th Percentile & $\begin{array}{l}\text { The } 75 \text { th percentile, where } 75 \% \text { of the sample values are below this value. Used with } \\
25 \text { th percentile to indicate the bounds for } 50 \% \text { of the data. }\end{array}$ \\
\hline 95th Percentile & The value where $95 \%$ of the sample values are below this value. \\
\hline $\mathrm{N}$ & The number of samples analyzed. \\
\hline $\mathrm{N}$ above detection & $\begin{array}{l}\text { The number of analyzed samples where the concentration was above the minimum } \\
\text { detectable amount (U qualifier in HEIS indicates value was below detection). }\end{array}$ \\
\hline
\end{tabular}

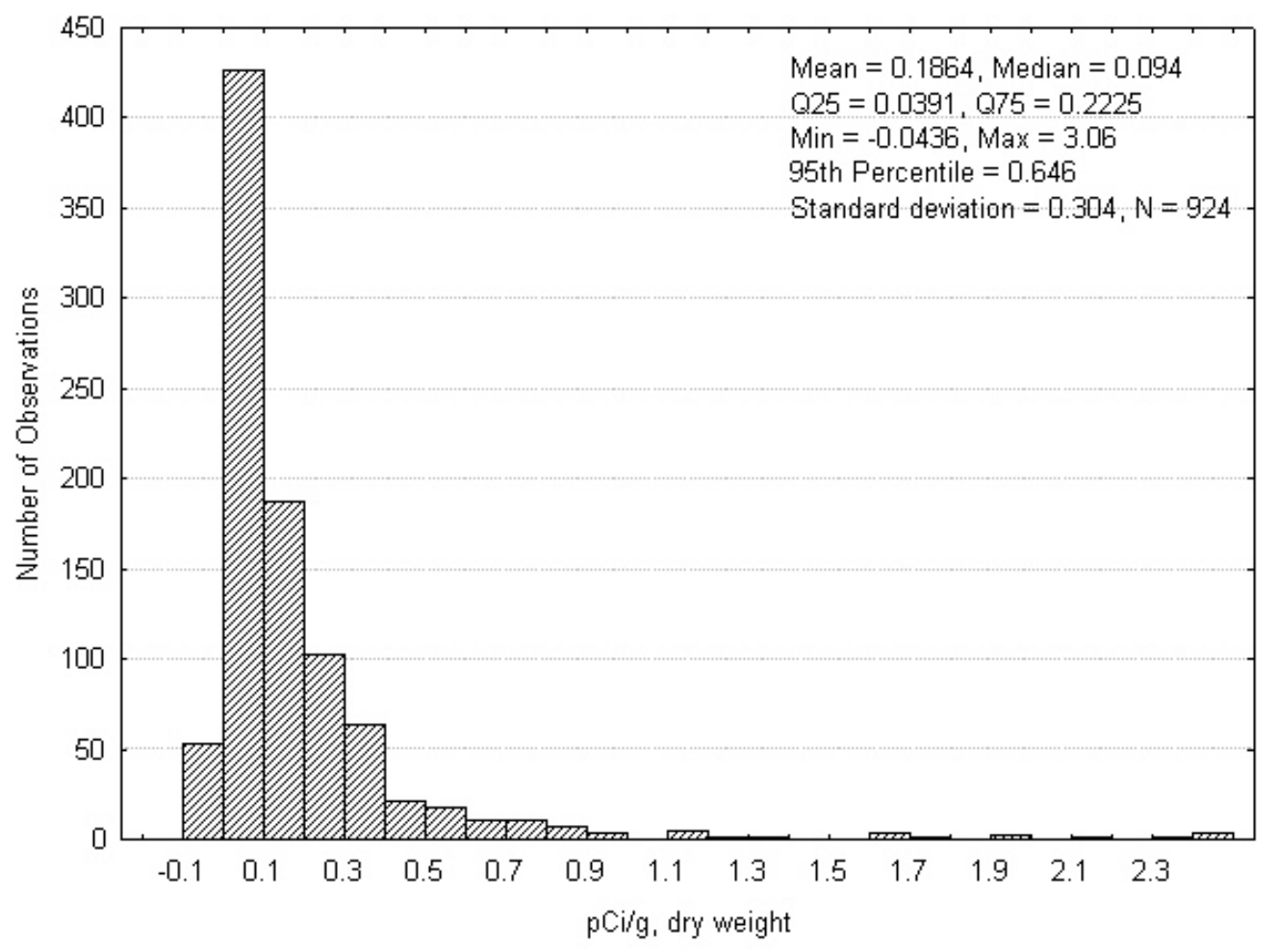

Figure 2.2. Concentration Data for Strontium-90 in Soil Samples 
occurred with the analysis, the MDA can exceed the MDC, resulting in a very high concentration that is essentially below detection. The proportion of samples below the MDC is similar to the number reported as "undetected" because the contractual limit is based on a number of factors, including measurement detection limits. Also, the actual detection limits (i.e., MDA) only recently have been reported for each analysis in the HEIS database; however, earlier data in HEIS carries the U qualifier to denote that the result did not exceed the MDA and was undetected (Table 2.5).

Table 2.5. Current (2008) Contractual Minimum Detectable Concentration ${ }^{(a)}$ for Radionuclides Evaluated in This Report

\begin{tabular}{llcc}
\hline Radionuclide & \multicolumn{1}{c}{ Analysis Method } & Soil $(\mathrm{pCi} / \mathrm{g})$ & Vegetation $(\mathrm{pCi} / \mathrm{g})$ \\
\hline${ }^{60} \mathrm{Co}$ & Gamma Spectrometry & 0.02 & 0.02 \\
${ }^{90} \mathrm{Sr}$ & Radiochemical & 0.05 & 0.05 \\
${ }^{137} \mathrm{Cs}$ & Gamma Spectrometry & 0.02 & 0.03 \\
${ }^{238} \mathrm{Pu}$ & Alpha Spectrometry & 0.0006 & 0.0006 \\
${ }^{239 / 240} \mathrm{Pu}$ & Alpha Spectrometry & 0.0006 & 0.0006 \\
${ }^{238} \mathrm{U}$ & Alpha Spectrometry & 0.02 & 0.1 \\
${ }^{238} \mathrm{U}$ & Low-Energy Photon & 1.0 & $\mathrm{NA}$ \\
${ }^{\text {total }} \mathrm{U}$ & Fluorometry & 0.01 & 0.01 \\
\hline
\end{tabular}

(a) Check section for historic changes in MDCs

Spatial trends were analyzed using a Kruskal-Wallis test on untransformed data (Gilbert 1987). When the Kruskal-Wallis test was significant, post-hoc comparisons of mean ranks of all pairs of groups were computed to evaluate which groups were different. Statistica $6.0^{1}$ was used to calculate the descriptive statistics and Kruskal-Wallis test. A probability value (p) of 0.05 was used to test for significance.

Temporal trends were evaluated using the Mann-Kendall test on untransformed data(Gilbert 1987; Helsel et al. 2006). The Mann-Kendall test is computed for individual sample locations and the results are combined into one overall test for a regional trend. The test is used to determine whether the same trend is evident across sample locations. To run this test, sample locations with data from a similar range of years were selected. Output from the test includes the Kendall test statistic and the slope of the overall trend. A computer program developed by the U.S. Geological Survey was used to run the tests (Helsel et al. 2006).

\subsection{Site Benchmarks and Guidance Levels}

To evaluate potential adverse impacts from the radionuclide concentrations to humans or ecological receptors, the analysis was expanded to compare sample concentrations to specific guidance values and benchmarks. These benchmarks include the contractual MDC; maximally exposed individual (MEI) dose levels; site surveillance soil screening levels; and, for biota, DOE biota dose guidance levels in soil.

\footnotetext{
${ }^{1}$ Statistica is a registered trademark of StatSoft, Inc., Tulsa, Oklahoma.
} 
Because uranium has a very long radiological half-life, it is considered more a chemical hazard than a radiological hazard.

Three assessments were conducted. The first evaluated the number of soil and vegetation samples with concentrations above the MDC. In the second assessment, the 95th percentile value of the distribution was compared to several standard benchmarks to evaluate potential impacts. These benchmarks were the Hanford Site Screening Level in the Site's Environmental Monitoring Plan (DOE 2008), the biota concentration guideline from RESRAD-BIOTA (DOE 2004), and the maximum internal dose rate. The third assessment involved comparing uranium concentrations to ecotoxicology benchmarks using the eco-risk concentrations proposed by Sheppard et al. (2006).

\subsubsection{Minimum Detected Concentrations}

The contractual MDC is one reference benchmark for assessing trends and analytical performance of surveillance data. MDCs are established based on the analytical technology and dose-based surveillance objectives. Contractual MDCs provided a balance between costs, technical limitations of the analytical methodology, and an assessment of needs to protect human health and the environment. However, the contractual MDC does not provide a direct comparison to the hazards or risk associated with exposure to radionuclides in soil or vegetation, either to man or to biota, and has been established at levels that are below minimum protective benchmarks where practical.

\subsubsection{Maximally Exposed Individual-Based Administrative Reporting Screens}

To assess the risk of exposure, we compared soil and vegetation concentrations against concentrations that would exceed the DOE public dose limit under accepted dose modeling and biota concentration guidelines developed under scientific consensus for screening dose rates to terrestrial wildlife and plants.

The 95th percentile was used as a conservative estimate of the maximum concentration. The actual maximum concentration was not used because of the potential for outliers. Outliers are defined as "an observation that does not conform to the pattern established by other observations" (Hunt et al. 1981) and are not uncommon in environmental pollution data (Gilbert 1987). In the analysis of radionuclide data, there are multiple sources of outliers. They can arise from transcription errors either in the field or in the laboratory, contamination of samples, and breakdowns or malfunctions of laboratory equipment.

Each year, the DOE calculates the maximum dose to a hypothetical member of the public that results from all environmental media that contain radiological contaminants from the Hanford Site. This individual is called the maximally exposed individual (MEI) and the dose contribution from soil is included in the computation. The offsite limit for radiological exposure resulting from Hanford operations is 100-mrem effective dose equivalent (EDE) per year whole body dose and has not been exceeded in any year that the Hanford Site has been in operation.

In 1990, the DOE established screening reporting levels for radionuclide concentrations in soil in the Hanford Site Environmental Monitoring Plan, currently in its fourth revision (DOE 2008). The DOE reporting level of 100 mrem from Hanford operations for the hypothetical MEI was used as a basis for establishing internal site-specific reporting levels for soil samples. These internal reporting levels were set from one to two orders of magnitude below the 100-mrem level. For cesium-137 and strontium-90, 
the Hanford Site reporting level is the soil concentration that would produce a conservative screening dose rate of 10-mrem 50-year EDE to an individual. The 50-year EDE is the cumulative dose over a 50-period that an individual would receive from radionuclides accumulated as a result of the exposure to the radionuclides in soil for 1 year. For uranium and plutonium isotopes, the modeled reporting levels are based on concentrations that would produce a 1-mrem 50-year EDE dose rate (DOE 2008). A higher dose rate is used for cesium-137 and strontium-90 because background fallout levels of these radionuclides are near the 1-mrem level. When the reporting level table was developed in 1989, concentrations of cobalt-60 in soil were predominantly at or below detection, and a reporting level was not published. However, the appropriate value for cobalt- 60 would be $0.3 \mathrm{pCi} / \mathrm{g}$ for a 10 -mrem reporting level. Since 1990, soil concentrations above these reporting levels were used by the surveillance program as a basis for screening results that may deviate from the normal distribution of radionuclides observed in soil surveillance samples. The exposure pathways include external exposure from the ground, recreational activities, inhalation, and drinking water ingestion.

\subsubsection{Biota Concentration Guidelines}

The DOE has established biota concentration guidelines (BCGs) based on conservative exposure scenarios for the protection of terrestrial animal populations (DOE 2002) using the RESRAD family of dose codes, specifically RESRAD-BIOTA (DOE 2004). The dose basis for these guidelines is $0.1 \mathrm{rad} / \mathrm{d}$ for terrestrial animals. Because the soil BCGs are based on a higher dose limit that is protective of animal populations, the benchmarks are higher than the DOE Hanford Site reporting limits based on offsite human exposure from soil exposure. Internal dose conversion factors were used to estimate dose rates to plants based on concentrations in vegetation samples, and these were in turn compared to the DOE dose guidance value of $1.0 \mathrm{rad} /$ day for the protection of terrestrial plant populations (DOE 2002).

\subsubsection{Uranium Ecotoxicological Benchmarks}

Ecotoxicological benchmarks have been proposed by Sheppard et al. (2006) for uranium and have been used to further compare surveillance data for soil. These are expressed as gravimetric units and not activity concentrations. 


\subsection{Results and Discussion}

This section summarizes the analyses of spatial and temporal trends in the concentrations of cobalt-60, cesium-137, strontium-90, plutonium-238, plutonium-239/240, and uranium (total and uranium-238) in soil and vegetation samples collected from 1971 through 2008. Concentrations were reported on a dry weight basis and have not been corrected for radiological decay. Spatially, the majority of samples were collected near the 200 Areas and temporally during the 1980 s. Trends over time and space were evaluated by decades and by the sampling regions defined in Section 2. Results are presented in tables throughout this section; figures supporting these results are in Appendixes A and B. Where possible, comparisons are made to soil background concentrations. Samples for background concentrations were taken at locations that DOE, PNNL, and the Washington State Department of Health considered uncontaminated by Hanford Site operations in a generally upwind (west) direction (DOE 1996). The section concludes with a discussion of dose consequences of radionuclides present in both soil and vegetation and the relationship to site environmental benchmarks and guidance levels.

The addition of land release data from ALE, the North Slope and the McGee/Riverlands area introduced a large number of values into the perimeter sampling area during the fourth study decade. Statistical tests for differences between the land release data and the routine surveillance data collect in the perimeter sampling area were performed for the radionuclides (Table 3.1). There was no difference between variance estimates or sample means for cobalt-60, cesium-137, plutonium-239/240, and uranium-238. The $F$-test for strontium-90 and plutonium-238 was significant, and the $t$-tests for mean differences means were also significant $(P<0.05)$; mean soil concentrations for the land release samples exceeded the means for the perimeter surveillance data collected in 2001, 2004, and 2008. For both radionuclides, a large percentage of the land release samples were below detection (about 59\%-60\%), which may have influenced both the $F$-test and $t$-test analysis. No partitioning of data was performed for the nonparametric tests of un-transformed data that follow for each of the six radionuclides.

\subsection{Cobalt-60}

Cobalt- 60 has a half-life of 5.3 years and was produced by neutron activation as a by-product of reactor operations. Other sources of cobalt-60 in the early years of sampling may have included fallout from weapons testing (http://www.stollereser.com/FactSheet/Cobalt.pdf). The sitewide background concentration (arithmetic mean) is $0.001 \mathrm{pCi} / \mathrm{g}$ dry weight (DOE 1996). Soil and vegetation samples analyzed for cobalt- 60 were collected in 1971 through 2008. More than $80 \%$ of the cobalt- 60 concentrations from soil and vegetation samples were below the analytical detection limit. Because of the relatively short half-
- Soil and vegetation samples from areas near the 100 Areas had the highest concentrations of cobalt- 60 .

- Overall, concentrations onsite exceeded those measured offsite.

- Over time, the concentrations in soil and vegetation samples have fallen below detection levels, with less than $1 \%$ of the soil samples collected in the 2000 s having concentrations above the MDA compared to approximately $47 \%$ in the 1970 s.

- Concentrations of cobalt-60 in soil and vegetation samples fall below applicable environmental benchmarks and site dose-based guidance levels (Section 3.7). 
Table 3.1. Comparison of Radionuclide Concentrations in Soil Samples Collected under the Routine Surveillance Program and the Land Release Initiatives at Perimeter Locations

\begin{tabular}{|c|c|c|c|c|c|c|c|c|}
\hline Radionuclide & Data Set & Mean & Median & Maximum & $\mathrm{N}$ & $\mathrm{N}<$ Det & $\begin{array}{c}F \text {-test } \\
\mathrm{P} \\
(\alpha=0.05)\end{array}$ & $\begin{array}{c}t \text {-test } \\
\mathrm{P} \\
(\alpha=0.05)\end{array}$ \\
\hline \multirow{2}{*}{ Cobalt-60 } & Land release & 0.001 & 0.001 & 0.026 & 117 & 117 & \multirow{2}{*}{0.059} & \multirow{2}{*}{0.46} \\
\hline & Surveillance & 0.0008 & 0.001 & 0.012 & 36 & 36 & & \\
\hline \multirow{2}{*}{ Cesium-137 } & Land release & 0.16 & 0.12 & 0.66 & 117 & 12 & \multirow{2}{*}{0.269} & \multirow{2}{*}{0.353} \\
\hline & Surveillance & 0.17 & 0.13 & 0.72 & 36 & 0 & & \\
\hline \multirow{2}{*}{ Strontium-90 } & Land release & 0.038 & 0.035 & 0.22 & 117 & 69 & \multirow{2}{*}{0.0009} & \multirow{2}{*}{$0.010^{\mathrm{a}}$} \\
\hline & Surveillance & 0.029 & 0.020 & 0.11 & 36 & 23 & & \\
\hline \multirow{2}{*}{ Plutonium-238 } & Land release & 0.0009 & 0.0005 & 0.0064 & 117 & 70 & \multirow{2}{*}{$<0.0001$} & \multirow{2}{*}{$<0.0001^{\text {(a) }}$} \\
\hline & Surveillance & 0.0003 & 0.0002 & 0.0019 & 34 & 22 & & \\
\hline \multirow{2}{*}{$\begin{array}{l}\text { Plutonium- } \\
239 / 240\end{array}$} & Land release & 0.0059 & 0.0044 & 0.0353 & 117 & 25 & \multirow{2}{*}{0.351} & \multirow{2}{*}{0.478} \\
\hline & Surveillance & 0.0059 & 0.0037 & 0.0301 & 33 & 2 & & \\
\hline \multirow{2}{*}{ Uranium-238 } & Land release & 0.232 & 0.164 & 2.88 & 116 & 8 & \multirow{2}{*}{0.158} & \multirow{2}{*}{0.089} \\
\hline & Surveillance & 0.311 & 0.171 & 1.34 & 36 & 2 & & \\
\hline
\end{tabular}

(a) Student's $t$-test based on unequal variance estimates.

life of cobalt-60, decay can have a profound effect on concentrations measured in soil and vegetation over the decades covered by this report.

\subsubsection{Soil}

Soil samples analyzed for cobalt-60 were collected yearly from 1971 through 1994 and then in 1998, 2001-2002, 2004-2006, and 2008. The maximum concentration of cobalt-60 was $2.37 \mathrm{pCi} / \mathrm{g}$ dry weight, in a soil sample collected in 1974 from an island at RM 340 in the Columbia River near the 300 Area. This observation may reflect particle contamination resulting from the discharge of corroded steel components from reactors (Sula et al. 1980; Poston et al. 2007). Eighty-three percent of samples had cobalt- 60 concentrations below the analytical detection limit, and nearly $40 \%$ of the samples had negative values. Mean and median concentrations of cobalt-60 in samples collected onsite were higher compared to offsite locations; however, this difference was not statistically significant $(P=0.051)$. Onsite locations also had a higher percentage of samples with concentrations above the detection limit compared to offsite ( $23 \%$ versus $12 \%$ ). There was no statistical difference in the median concentration of cobalt-60 from the three offsite areas: perimeter, nearby, and distant sample sites (Table 3.2). Only 6\% of the samples from distant sites exceeded the MDA, while $14 \%$ of the perimeter samples exceeded the detection limit. 
Table 3.2. Cobalt-60 Concentrations (pCi/g dry weight) in Soil Samples Collected Onsite and at Various Distances from the Hanford Site (results not decay-corrected)

\begin{tabular}{|c|c|c|c|c|}
\hline Statistics & Onsite & Perimeter & Nearby & Distant \\
\hline Median & 0.003 & 0.001 & 0.000 & 0.002 \\
\hline Mean & 0.018 & 0.011 & 0.007 & 0.001 \\
\hline Standard Deviation & 0.130 & 0.126 & 0.030 & 0.013 \\
\hline Minimum & -0.067 & -0.067 & -0.032 & -0.056 \\
\hline Maximum & 2.14 & 2.37 & 0.15 & 0.032 \\
\hline 25th Percentile ${ }^{(a)}$ & -0.004 & -0.004 & -0.006 & -0.006 \\
\hline 75th Percentile ${ }^{(a)}$ & 0.016 & 0.009 & 0.010 & 0.008 \\
\hline 95th Percentile & 0.066 & 0.043 & 0.091 & 0.024 \\
\hline $\mathrm{N}^{(\mathrm{b})}$ & 410 & 361 & 78 & 78 \\
\hline $\mathrm{N}$ above detection ${ }^{(\mathrm{c})}$ & 95 & 50 & 9 & 5 \\
\hline
\end{tabular}

(a) Fifty percent of the data occurs between these two endpoints.

(b) Number of samples.

(c) Number of samples above the analytical detection limit.

For soil samples collected onsite, the highest concentrations (95th percentile) were found in samples from the 100 Area, followed by soil samples from the 300 Area, 600 Area, perimeter, 200 Area, and 400 Area (Table 3.3). Over $30 \%$ of the samples from the 100 Area and perimeter locations were above the MDA, while less than $20 \%$ of the samples from the other onsite areas had cobalt- 60 concentrations above the MDA. Along with the spatial difference in the concentration of cobalt- 60 in soil samples, there has been a temporal decline in the number of samples exceeding the MDA. Since the 1970s, for onsite samples, the percentage of samples exceeding the MDA has gone from $58 \%$ in the 1970 s to $1 \%$ in the 2000 s. For offsite samples, the percentage has declined from $37 \%$ to $0 \%$ from the 1970 s to 2000 s.

Table 3.3. Cobalt- 60 Concentrations (pCi/g dry weight) in Soil Samples Collected in Different Areas on the Hanford Site (onsite)

\begin{tabular}{|c|c|c|c|c|c|c|}
\hline Statistics & 100 Area & 200 Area & 300 Area & 400 Area & 600 Area & Perimeter \\
\hline Median & 0.011 & 0.000 & 0.001 & 0.001 & 0.005 & 0.001 \\
\hline Mean & 0.052 & 0.013 & 0.008 & 0.000 & 0.014 & 0.008 \\
\hline Standard Deviation & 0.250 & 0.118 & 0.035 & 0.014 & 0.034 & 0.029 \\
\hline Minimum & -0.038 & -0.0672 & -0.049 & -0.037 & -0.052 & -0.030 \\
\hline Maximum & 2.14 & 1.4 & 0.15 & 0.0392 & 0.147 & 0.123 \\
\hline 25th Percentile ${ }^{(a)}$ & 0.001 & -0.008 & -0.005 & -0.005 & -0.003 & -0.005 \\
\hline 75th Percentile ${ }^{(a)}$ & 0.029 & 0.010 & 0.009 & 0.006 & 0.023 & 0.013 \\
\hline 95th Percentile & 0.102 & 0.050 & 0.071 & 0.022 & 0.068 & 0.063 \\
\hline $\mathrm{N}^{(\mathrm{b})}$ & 74 & 149 & 41 & 41 & 64 & 41 \\
\hline $\mathrm{N}$ above detection ${ }^{(\mathrm{c})}$ & 27 & 28 & 6 & 5 & 22 & 7 \\
\hline
\end{tabular}

(a) Fifty percent of the data occurs between these two endpoints.

(b) Number of samples.

(c) Number of samples above the analytical detection limit. 
Temporally, cobalt-60 concentrations in onsite soil samples have decreased significantly $(P=0.024$; slope $=-0.0001)$; offsite, the change over time was not significant $(P=0.26)$, while slope of the change was zero. Since the 1980s, the mean (and median) cobalt-60 concentrations in soil samples have changed little (Table 3.4; Figure 3.1). However, the data have become less variable with time, characterized by smaller standard deviations as more values approach the limit of detection (Table 3.4). The lack of noticeable change since 1980 is probably a result of the shutdown of the single-pass reactors in the 1970s and a lack of a significant vector or release from Hanford Site operations and waste management areas. It appears with no additional inputs of cobalt- 60 , levels of cobalt- 60 have dropped below the ability to be measured by current routine monitoring technology.

Table 3.4. Cobalt-60 Concentrations (pCi/g dry weight) in Soil Samples Collected from Areas On and Around the Hanford Site by Decade

\begin{tabular}{|c|c|c|c|c|c|c|c|c|}
\hline \multirow[b]{2}{*}{ Statistics } & \multicolumn{4}{|c|}{ Onsite } & \multicolumn{4}{|c|}{ Offsite } \\
\hline & 1970 & 1980 & 1990 & 2000 & 1970 & 1980 & 1990 & 2000 \\
\hline Median & 0.016 & 0.001 & 0.001 & 0.001 & 0 & 0.000 & 0.001 & 0.001 \\
\hline Mean & 0.061 & 0.004 & 0.004 & 0.004 & 0.040 & 0.002 & 0.001 & 0.002 \\
\hline Standard Deviation & 0.254 & 0.025 & 0.035 & 0.013 & 0.237 & 0.019 & 0.017 & 0.010 \\
\hline Minimum & -0.051 & -0.067 & -0.049 & -0.013 & -0.040 & -0.067 & -0.040 & -0.028 \\
\hline Maximum & 2.14 & 0.102 & 0.28 & 0.093 & 2.37 & 0.079 & 0.062 & 0.101 \\
\hline 25th Percentile ${ }^{(a)}$ & 0 & -0.010 & -0.005 & -0.002 & 0 & -0.008 & -0.005 & -0.004 \\
\hline 75th Percentile ${ }^{(a)}$ & 0.047 & 0.015 & 0.009 & 0.007 & 0.029 & 0.011 & 0.008 & 0.005 \\
\hline 95th Percentile & 0.147 & 0.050 & 0.025 & 0.023 & 0.098 & 0.032 & 0.032 & 0.015 \\
\hline $\mathrm{N}^{(\mathrm{b})}$ & 101 & 158 & 75 & 76 & 101 & 172 & 57 & 187 \\
\hline $\mathrm{N}$ above detection $^{(\mathrm{c})}$ & 58 & 25 & 11 & 1 & 37 & 23 & 4 & 0 \\
\hline
\end{tabular}

(a) Fifty percent of the data occurs between these two endpoints.

(b) Number of samples.

(c) Number of samples above the analytical detection limit.

\subsubsection{Vegetation}

Vegetation samples were collected yearly from 1971 through 1994 and then in 1997, 1998, 2001, 2004, and 2008. When the results for cobalt-60 concentration in vegetation were plotted over time, results from 1973 and 1974 were nearly all below zero and one to three orders of magnitude smaller than values reported after 1975 (Figure 3.2). This difference was probably due to a change in the analysis method. Vegetation samples before 1975 were analyzed via gamma spectrometry using a sodium iodide crystal, whereas vegetation samples collected after that date were analyzed with germanium lithium crystal technology (Nees and Corley 1974; Fix 1975). The following discussion is based on samples collected after 1974. 


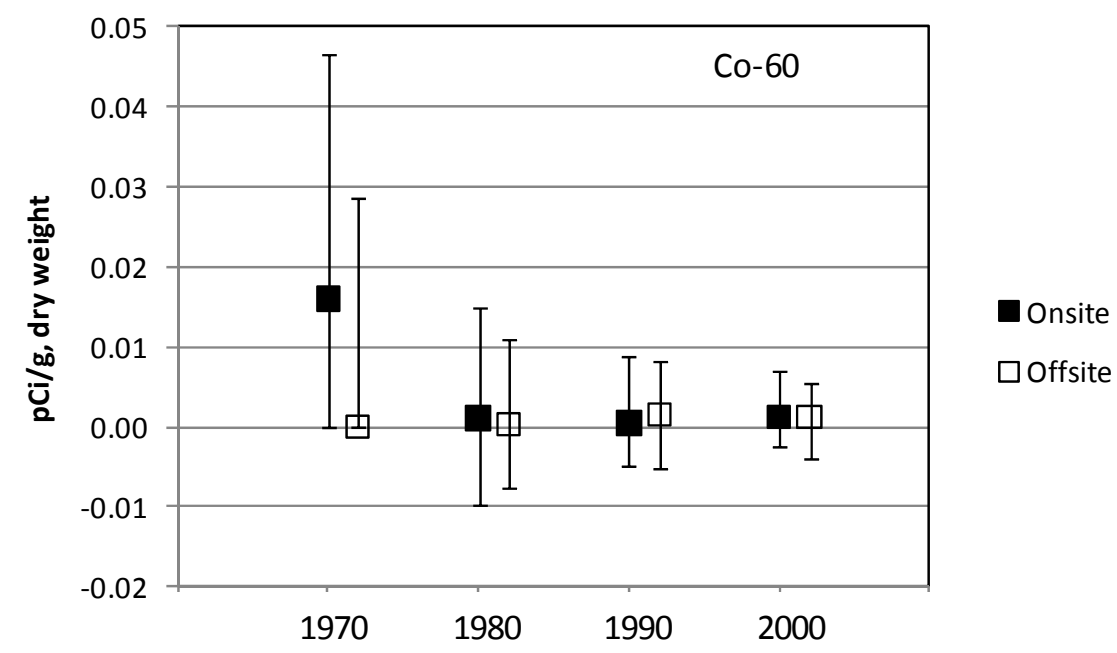

Figure 3.1. Median Cobalt- 60 Concentrations (pCi/g dry weight) in Soil Samples Collected from Onsite (i.e., 100, 200, 300, 400, and 600 Areas) and Offsite (i.e., perimeter, nearby, and distant) Areas by Decade. Error bars encompass $50 \%$ of the data around the median.

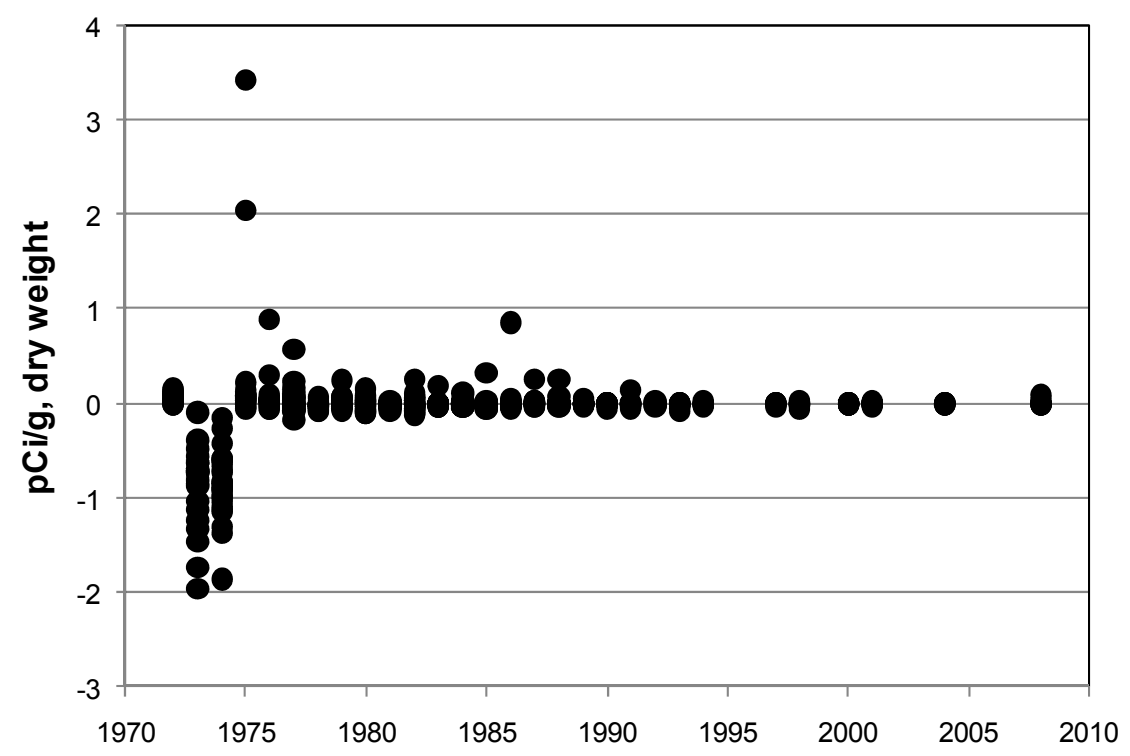

Figure 3.2. Cobalt-60 Concentrations (pCi/g dry weight) in Perennial Vegetation Samples Collected On and Around the Hanford Site Between 1972 and 2008

In the nearly 30 years of vegetation sampling, cobalt-60 concentrations ranged from -0.163 to $3.43 \mathrm{pCi} / \mathrm{g}$; the highest concentration was collected in 1975 from plants in the 100 Area. Overall, only $15 \%$ of the cobalt- 60 concentrations exceeded the analytical detection limit. Cobalt- 60 in plants comes primarily from surface deposition of windblown contaminated soils or fallout, although some cobalt-60 may be absorbed through the roots. It readily forms precipitates in alkaline soils like those found at Hanford, and it is more prone to accumulate in roots rather than stems and leaves (Coughtrey and Thorne 1983).

Cobalt-60 concentrations were significantly higher in vegetation samples collected onsite compared to those collected at offsite locations (Table 3.5). In addition, $21 \%$ of the onsite samples were above the 
MDA compared to less than $10 \%$ of the offsite samples (Table 3.5). Cobalt-60 concentrations in vegetation samples from perimeter and nearby sites had negative median values, indicating that over $50 \%$ of the samples had negative values.

Table 3.5. Cobalt-60 Concentrations (pCi/g dry weight) in Vegetation Samples (1975 through 2008) Collected on the Hanford Site (onsite) and at Various Distances from the Hanford Site

\begin{tabular}{|c|c|c|c|c|}
\hline Statistics & Onsite & Perimeter & Nearby & Distant \\
\hline Median & 0.005 & -0.0005 & -0.0004 & 0.00305 \\
\hline Mean & 0.046 & -0.002 & 0.003 & 0.005 \\
\hline Standard Deviation & 0.260 & 0.033 & 0.045 & 0.028 \\
\hline Minimum & -0.106 & -0.163 & -0.078 & -0.061 \\
\hline Maximum & 3.43 & 0.108 & 0.251 & 0.179 \\
\hline 25th Percentile (a) $^{(a)}$ & -0.007 & -0.014 & -0.010 & -0.005 \\
\hline 75th Percentile ${ }^{(a)}$ & 0.023 & 0.009 & 0.010 & 0.011 \\
\hline 95th Percentile & 0.165 & 0.059 & 0.074 & 0.029 \\
\hline $\mathrm{N}^{(\mathrm{b})}$ & 271 & 178 & 54 & 59 \\
\hline $\mathrm{N}$ above detection ${ }^{(\mathrm{c})}$ & 56 & 16 & 4 & 6 \\
\hline
\end{tabular}

(a) Fifty percent of the data occurs between these two endpoints.

(b) Number of samples.

(c) Number of samples above the analytical detection limit.

For samples collected onsite, the 95th percentile cobalt-60 concentrations in vegetation samples were highest from the 100 Areas, followed by the 200 Area, 400 and 600 Areas, perimeter, and the 300 Area (Table 3.6). Thirty-nine percent of vegetation samples from the 100 Areas had concentrations above the detection limit compared to $26 \%$ of the samples from the 300 Area.

Table 3.6. Cobalt- 60 Concentrations (pCi/g dry weight) in Vegetation Samples (1975 through 2008) Collected within Different Areas on the Hanford Site

\begin{tabular}{|c|c|c|c|c|c|c|}
\hline Location & 100 Area & 200 Area & 300 Area & 400 Area & 600 Area & Perimeter \\
\hline Median & 0.016 & 0.001 & 0.006 & 0.003 & 0.007 & 0.006 \\
\hline Mean & 0.135 & 0.038 & 0.006 & 0.020 & 0.031 & 0.004 \\
\hline Standard Deviation & 0.492 & 0.225 & 0.030 & 0.046 & 0.143 & 0.044 \\
\hline Minimum & -0.015 & -0.103 & -0.106 & -0.034 & -0.066 & -0.090 \\
\hline Maximum & 3.43 & 2.06 & 0.096 & 0.15 & 0.898 & 0.093 \\
\hline 25th Percentile ${ }^{(a)}$ & 0.002 & -0.009 & -0.003 & -0.008 & -0.010 & -0.016 \\
\hline 75th Percentile ${ }^{(a)}$ & 0.077 & 0.012 & 0.015 & 0.029 & 0.024 & 0.024 \\
\hline 95th Percentile & 0.327 & 0.165 & 0.033 & 0.128 & 0.097 & 0.086 \\
\hline $\mathrm{N}^{(\mathrm{b})}$ & 51 & 93 & 31 & 28 & 41 & 27 \\
\hline $\mathrm{N}$ above detection ${ }^{(\mathrm{c})}$ & 20 & 11 & 8 & 6 & 8 & 3 \\
\hline
\end{tabular}

(a) Fifty percent of the data occurs between these two endpoints.

(b) Number of samples.

(c) Number of samples above the analytical detection limit. 
Onsite cobalt-60 concentrations in vegetation samples were higher by an order of magnitude, and more variable in the 1970s compared to the 1980s, 1990s, and 2000s (Table 3.7; Figure 3.3); however, the trend was not significant $(P=0.20$; slope $=-0.00011)$. There appears to be little change in the median concentrations either onsite or offsite since the early 1980s. As with the soil samples, variability has been declining in cobalt- 60 concentrations in vegetation samples in the last $20+$ years, and the percentage of samples with concentrations above the MDA has fallen from $34 \%$ in the 1970 s to less than $2 \%$ today.

Table 3.7. Cobalt-60 Concentrations (pCi/g dry weight) in Vegetation Samples Collected On and Around the Hanford Site by Decade

\begin{tabular}{|c|c|c|c|c|c|c|c|c|}
\hline \multirow[b]{2}{*}{ Statistics } & \multicolumn{4}{|c|}{ Onsite } & \multicolumn{4}{|c|}{ Offsite } \\
\hline & 1970 & 1980 & 1990 & 2000 & 1970 & 1980 & 1990 & 2000 \\
\hline Median & 0.046 & 0.003 & 0.002 & 0.002 & -0.017 & 0.000 & 0.002 & 0.003 \\
\hline Mean & 0.172 & 0.017 & 0.004 & 0.004 & 0.000 & -0.001 & 0.001 & 0.004 \\
\hline Standard Deviation & 0.537 & 0.089 & 0.032 & 0.022 & 0.069 & 0.026 & 0.014 & 0.010 \\
\hline Minimum & -0.066 & -0.106 & -0.078 & -0.016 & -0.163 & -0.095 & -0.037 & -0.014 \\
\hline Maximum & 3.43 & 0.865 & 0.148 & 0.0959 & 0.251 & 0.0977 & 0.0295 & 0.0381 \\
\hline 25th Percentile ${ }^{(a)}$ & 0.006 & -0.009 & -0.003 & -0.005 & -0.043 & -0.009 & -0.010 & -0.002 \\
\hline 75th Percentile ${ }^{(a)}$ & 0.091 & 0.014 & 0.013 & 0.006 & 0.027 & 0.010 & 0.010 & 0.009 \\
\hline 95th Percentile & 0.898 & 0.119 & 0.035 & 0.011 & 0.108 & 0.035 & 0.023 & 0.023 \\
\hline $\mathrm{N}^{(\mathrm{b})}$ & 56 & 154 & 39 & 22 & 47 & 157 & 51 & 36 \\
\hline $\mathrm{N}$ above detection ${ }^{(\mathrm{c})}$ & 28 & 23 & 4 & 1 & 7 & 17 & 2 & 0 \\
\hline
\end{tabular}

(a) Fifty percent of the data occurs between these two endpoints.

(b) Number of samples.

(c) Number of samples above the analytical detection limit.

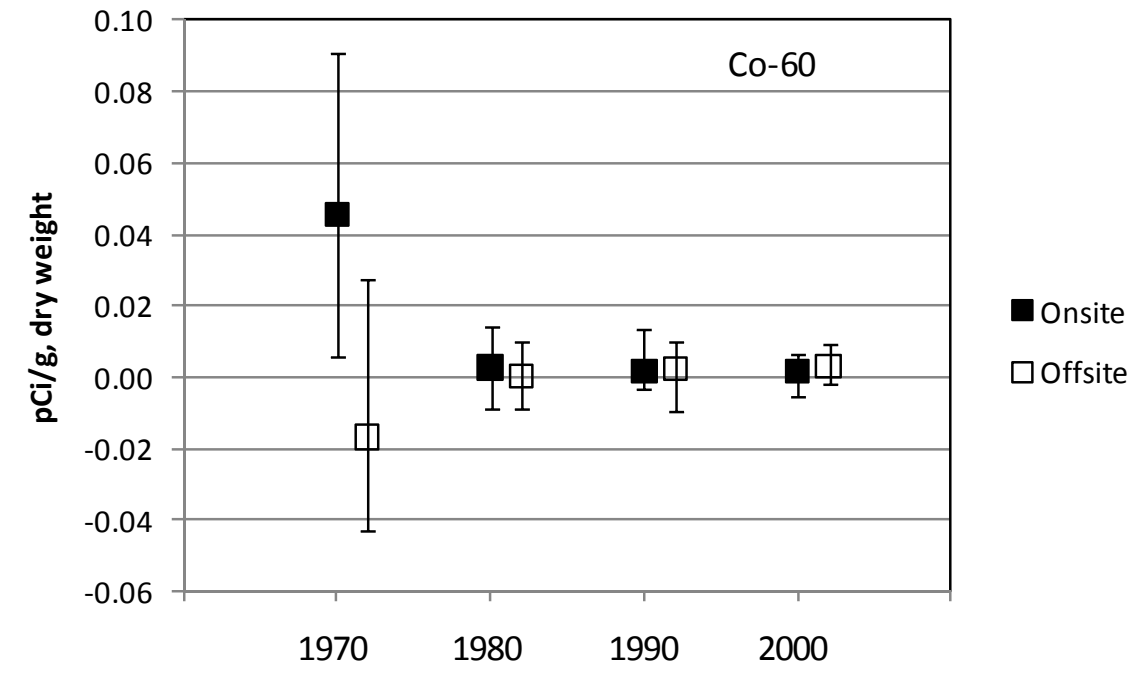

Figure 3.3. Median Cobalt- 60 Concentrations (pCi/g dry weight) in Vegetation Samples Collected from Onsite (i.e., 100, 200, 300, 400, and 600 Areas) and Offsite (i.e., perimeter, nearby, and distant) Areas by Decade. Error bars encompass $50 \%$ of the data around the median. 


\subsection{Cesium-137}

Cesium-137 is a beta-emitting radionuclide with a half-life of 30 years and has a very short half-lived daughter, barium-137m, that emits a gamma photon. Sources of cesium-137 at the Hanford Site include processing of spent nuclear fuel and radioactive wastes resulting from nuclear reactor operations (http://www.ead.anl.gov/pub/doc/ cesium.pdf). Cesium-137 also was deposited as fallout from atmospheric testing and from the Chernobyl accident. The average background concentration of cesium-137 in Hanford Site soils as determined in 1995 was $0.42 \mathrm{pCi} / \mathrm{g}$ dry weight (DOE 1996).

\subsubsection{Soil}

Cesium-137 was analyzed in routine soil samples collected annually from 1971 through 1994, and in 1997, 1998, 2000-2001, 2004-2006, and 2008. The maximum cesium-137 concentration was $35.2( \pm 0.5) \mathrm{pCi} / \mathrm{g}$ dry weight, in a sample from the 200 Area in 1979. Cesium-137 has a large potential to adsorb to soil and is retained in the upper soil horizons of the soil column (Price 1991).

Cesium-137 concentrations in soil samples from onsite areas were significantly higher than concentrations in samples from offsite locations $(P<0.0001)$. This conclusion is evident in the mean and median as well as the 75th and 95th percentiles and the maximum values (Table 3.8). The significant difference between onsite and offsite sample sites is a reflection of the onsite source of the cesium-137, primarily fuel processing and waste management activities in the 200 Areas. There was little difference in the number of samples above the MDA; it varied from $94 \%$ for samples collected in the nearby community region to $98 \%$ for onsite samples.

For onsite soil samples, cesium-137 concentrations were significantly different among areas; samples from near the 200 Areas had higher concentrations than samples from the 100, 300, 400, and 600 Areas $(P<0.0001)$ (Table 3.9). Cesium-137 concentrations for soil samples from the 400 Area were significantly lower than for samples from the other areas $(P<0.01)$. Fuel processing and waste management activities in the 200 Areas are the primary sources of cesium-137.

Cesium-137 concentrations in soil samples were similar between the 1970s and 1980s and then decreased between the 1980s and 2000s (Table 3.10; Figure 3.4). The decline occurred for soil samples for both onsite $(P<0.0001$, slope $=-0.0104 \mathrm{pCi} / \mathrm{g} / \mathrm{yr})$ and offsite $(P<0.0001$, slope $=-0.0114 \mathrm{pCi} / \mathrm{g} / \mathrm{yr})$. The magnitude of decline is consistent with radiological decay and no significant accumulation over the sampling period. 
Table 3.8. Cesium-137 Concentration (pCi/g dry weight) in Soil Samples (1971 through 2008) Collected on the Hanford Site (onsite) and at Various Distances from the Hanford Site

\begin{tabular}{|c|c|c|c|c|}
\hline Statistics & Onsite & Perimeter & Nearby & Distant \\
\hline Median & 0.532 & 0.246 & 0.512 & 0.25 \\
\hline Mean & 1.527 & 0.383 & 0.537 & 0.351 \\
\hline Standard Deviation & 4.223 & 0.396 & 0.362 & 0.329 \\
\hline Minimum & -0.0158 & -0.0125 & -0.0111 & -0.0195 \\
\hline Maximum & 35.2 & 2.18 & 1.74 & 1.52 \\
\hline 25th Percentile ${ }^{(a)}$ & 0.198 & 0.112 & 0.273 & 0.114 \\
\hline 75th Percentile ${ }^{(a)}$ & 1.02 & 0.489 & 0.752 & 0.479 \\
\hline 95th Percentile & 4.78 & 1.2 & 1.19 & 1.15 \\
\hline $\mathrm{N}^{(\mathrm{b})}$ & 410 & 361 & 78 & 78 \\
\hline $\mathrm{N}$ above detection ${ }^{(\mathrm{c})}$ & 402 & 346 & 73 & 74 \\
\hline
\end{tabular}

(a) Fifty percent of the data occurs between these two endpoints.

(b) Number of samples.

(c) Number of samples above the analytical detection limit.

Table 3.9. Cesium-137 Concentration (pCi/g dry weight) in Soil Samples (1971 through 2008) Collected from Various Areas on the Hanford Site

\begin{tabular}{|c|c|c|c|c|c|c|}
\hline Statistics & 100 Area & 200 Area & 300 Area & 400 Area & 600 Area & Perimeter \\
\hline Median & 0.542 & 0.744 & 0.509 & 0.126 & 0.599 & 0.362 \\
\hline Mean & 0.599 & 3.294 & 0.564 & 0.202 & 0.642 & 0.456 \\
\hline Standard Deviation & 0.380 & 6.637 & 0.393 & 0.273 & 0.490 & 0.314 \\
\hline Minimum & 0.00993 & 0.0113 & -0.0056 & 0.00312 & -0.0158 & 0.0357 \\
\hline Maximum & 1.8 & 35.2 & 1.5 & 1.68 & 2.13 & 1.19 \\
\hline 25th Percentile ${ }^{(a)}$ & 0.319 & 0.313 & 0.254 & 0.078 & 0.190 & 0.213 \\
\hline 75th Percentile ${ }^{(a)}$ & 0.768 & 2.11 & 0.774 & 0.198 & 0.937 & 0.732 \\
\hline 95th Percentile & 1.3 & 21.2 & 1.23 & 0.519 & 1.57 & 0.945 \\
\hline $\mathrm{N}^{(\mathrm{b})}$ & 74 & 149 & 41 & 41 & 64 & 41 \\
\hline $\mathrm{N}$ above detection ${ }^{(\mathrm{c})}$ & 73 & 148 & 39 & 40 & 61 & 41 \\
\hline
\end{tabular}

(a) Fifty percent of the data occurs between these two endpoints.

(b) Number of samples.

(c) Number of samples above the analytical detection limit. 
Table 3.10.Cesium-137 (pCi/g dry weight) in Soil Samples Collected from Areas On and Around the Hanford Site by Decade

\begin{tabular}{|c|c|c|c|c|c|c|c|c|}
\hline \multirow[b]{2}{*}{ Statistics } & \multicolumn{4}{|c|}{ Onsite } & \multicolumn{4}{|c|}{ Offsite } \\
\hline & 1970 & 1980 & 1990 & 2000 & 1970 & 1980 & 1990 & 2000 \\
\hline Median & 0.627 & 0.7075 & 0.357 & 0.2125 & 0.478 & 0.452 & 0.333 & 0.122 \\
\hline Mean & 1.676 & 2.232 & 0.813 & 0.569 & 0.600 & 0.538 & 0.422 & 0.163 \\
\hline Standard Deviation & 4.802 & 5.242 & 1.891 & 1.717 & 0.435 & 0.414 & 0.342 & 0.144 \\
\hline Minimum & -0.0158 & 0.0113 & 0.00312 & -0.00559 & 0 & 0.0253 & 0.0017 & -0.0195 \\
\hline Maximum & 35.2 & 28.1 & 12.3 & 11.8 & 1.91 & 2.18 & 1.78 & 0.712 \\
\hline 25th Percentile (a) $^{(2)}$ & 0.35 & 0.325 & 0.188 & 0.079 & 0.263 & 0.227 & 0.167 & 0.051 \\
\hline 75 th Percentile ${ }^{(a)}$ & 1.19 & 1.17 & 0.66 & 0.450 & 0.836 & 0.757 & 0.583 & 0.241 \\
\hline 95th Percentile & 3.01 & 17.9 & 2.29 & 1.13 & 1.52 & 1.4 & 1.19 & 0.466 \\
\hline $\mathrm{N}^{(\mathrm{b})}$ & 101 & 158 & 75 & 76 & 101 & 172 & 57 & 187 \\
\hline $\mathrm{N}$ above detection ${ }^{(\mathrm{c})}$ & 100 & 157 & 73 & 72 & 100 & 171 & 55 & 167 \\
\hline
\end{tabular}

(a) Fifty percent of the data occurs between these two endpoints.

(b) Number of samples.

(c) Number of samples above the analytical detection limit.

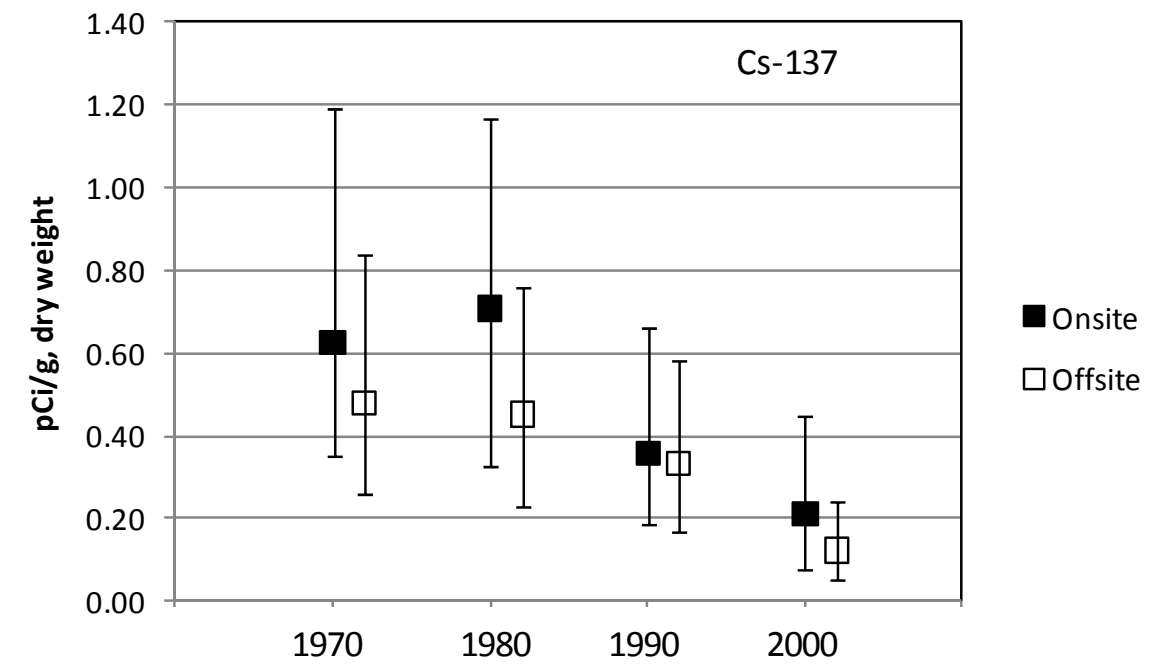

Figure 3.4. Median Cesium-137 Concentrations (pCi/g dry weight) in Soil Samples Collected from Onsite (i.e., 100, 200, 300, 400, and 600 Areas) and Offsite (i.e., perimeter, nearby, and distant) Areas by Decade. Error bars encompass $50 \%$ of the data around the median.

\subsubsection{Vegetation}

Analysis of cesium-137 in vegetation samples was based on samples collected from 1971 through 1994, 1997, 1998, 2000, 2001, 2004, and 2008. The maximum cesium-137 concentration was recorded in 1972 from a vegetation sample collected in the 200 Area (120 pCi/g dry weight). Approximately $42 \%$ of the vegetation samples had cesium-137 concentrations below the MDA. 
The concentration of cesium-137 in vegetation samples was highest in samples collected onsite (Table 3.11); concentrations declined as distance from the site increased. Samples from distant locations had the lowest concentrations (Table 3.11). Samples from distant sites were more likely to fall below the detection limit (66\%), while only $32 \%$ of onsite samples were below the MDA.

Table 3.11. Cesium-137 Concentration (pCi/g dry weight) in Vegetation Samples (1971 through 2008) Collected on the Hanford Site (onsite) and at Various Distances from the Hanford Site

\begin{tabular}{|c|c|c|c|c|}
\hline Statistics & Onsite & Perimeter & Nearby & Distant \\
\hline Median & 0.038 & 0.024 & 0.022 & 0.012 \\
\hline Mean & 1.082 & 0.215 & 0.117 & 0.060 \\
\hline Standard Deviation & 7.807 & 0.598 & 0.249 & 0.172 \\
\hline Minimum & -0.0463 & -0.267 & -0.0366 & -0.00986 \\
\hline Maximum & 120 & 5.8 & 1.39 & 0.975 \\
\hline 25th Percentile ${ }^{(a)}$ & 0.011 & 0.006 & 0.009 & 0.004 \\
\hline 75th Percentile ${ }^{(a)}$ & 0.160 & 0.154 & 0.12 & 0.029 \\
\hline 95th Percentile & 1.94 & 1.19 & 0.558 & 0.337 \\
\hline $\mathrm{N}^{(\mathrm{b})}$ & 312 & 218 & 68 & 59 \\
\hline $\mathrm{N}$ above detection ${ }^{(\mathrm{c})}$ & 212 & 115 & 32 & 20 \\
\hline
\end{tabular}

(a) Fifty percent of the data occurs between these two endpoints.

(b) Number of samples.

(c) Number of samples above the analytical detection limit.

There were significant differences in concentrations from the different onsite sample areas $(P<0.0001)$. Vegetation samples from the 200 Area had the highest concentrations (95th percentile), and those from 400 Area had the lowest (Table 3.12). In addition, $87 \%$ of vegetation samples from the 200 Area had concentrations above the detection limit, while $65 \%$ of the samples from the 400 Area were above the MDA.

Table 3.12. Cesium-137 Concentration (pCi/g dry weight) in Vegetation Samples (1971 through 2008) Collected from Various Areas on the Hanford Site

\begin{tabular}{|c|c|c|c|c|c|c|}
\hline Statistics & 100 Area & 200 Area & 300 Area & 400 Area & 600 Area & Perimeter \\
\hline Median & 0.015 & 0.074 & 0.013 & 0.035 & 0.049 & 0.05 \\
\hline Mean & 0.174 & 2.669 & 0.069 & 0.070 & 0.554 & 0.171 \\
\hline Standard Deviation & 0.942 & 13.042 & 0.131 & 0.098 & 2.283 & 0.340 \\
\hline Minimum & -0.0171 & -0.0264 & -0.0073 & -0.0275 & -0.0463 & -0.0262 \\
\hline Maximum & 6.97 & 120 & 0.487 & 0.391 & 16.3 & 1.67 \\
\hline 25th Percentile ${ }^{(a)}$ & 0.004 & 0.029 & 0.008 & 0.010 & 0.009 & 0.011 \\
\hline 75th Percentile ${ }^{(a)}$ & 0.035 & 0.278 & 0.039 & 0.081 & 0.209 & 0.179 \\
\hline 95th Percentile & 0.307 & 11.3 & 0.456 & 0.268 & 1.94 & 1.03 \\
\hline $\mathrm{N}^{(\mathrm{b})}$ & 55 & 108 & 35 & 28 & 54 & 32 \\
\hline $\mathrm{N}$ above detection ${ }^{(\mathrm{c})}$ & 26 & 94 & 17 & 18 & 35 & 22 \\
\hline
\end{tabular}

(a) Fifty percent of the data occurs between these two endpoints.

(b) Number of samples.

(c) Number of samples above the analytical detection limit. 
Cesium-137 concentrations in vegetation samples decreased significantly over the analysis period (onsite: $P<0.0001$, slope $=-0.0062 \mathrm{pCi} / \mathrm{g} / \mathrm{yr}$; offsite: $P<0.0001$, slope $=-0.0015 \mathrm{pCi} / \mathrm{g} / \mathrm{yr}$ ). Between the 1970s and 1980s, cesium-137 concentrations in vegetation samples decreased substantially both onsite and offsite (Table 3.13; Figure 3.5). Since the 1980s, there has been little change in the mean or median concentration; however, the variability has continued to decrease, as have the 75th and 95th percentiles, which indicates the range of values is smaller and closer to the median. The plateau in soil concentrations observed in the 1980s may indicate that environmental conditions more effectively sequestered cesium137 over time, making it less available for translocation from the soil to plants, or it may reflect decreases in atmospheric fallout over that period. As with cobalt-60, since the decommissioning of the reactors and the shutdown of the processing facilities, no new cesium-137 has been added to the environment (with the exception of Chernobyl), and what was historically deposited is decaying. The maximum concentration since 2000 was $0.055 \mathrm{pCi} / \mathrm{g}$ dry weight in a sample from near the 200 Area. Nearly all samples collected during the 1970s were above the detection limit (88\%); this fell to $57 \%$ in the 1980 s, to $31 \%$ in the 1990 s, and to $2 \%$ in the samples collected in the 2000 s.

Table 3.13. Cesium-137 Concentrations (pCi/g dry weight) in Vegetation Samples Collected On and Around the Hanford Site by Decade

\begin{tabular}{|c|c|c|c|c|c|c|c|c|}
\hline \multirow[b]{2}{*}{ Statistics } & \multicolumn{4}{|c|}{ Onsite } & \multicolumn{4}{|c|}{ Offsite } \\
\hline & 1970 & 1980 & 1990 & 2000 & 1970 & 1980 & 1990 & 2000 \\
\hline Median & 0.226 & 0.025 & 0.012 & 0.006 & 0.191 & 0.016 & 0.007 & 0.008 \\
\hline Mean & 3.418 & 0.054 & 0.023 & 0.008 & 0.409 & 0.104 & 0.010 & 0.007 \\
\hline Standard Deviation & 13.839 & 0.085 & 0.037 & 0.014 & 0.774 & 0.321 & 0.013 & 0.009 \\
\hline Minimum & -0.0463 & -0.0275 & -0.0262 & -0.0123 & -0.267 & -0.0749 & -0.0135 & -0.0121 \\
\hline Maximum & 120 & 0.566 & 0.164 & 0.055 & 5.8 & 1.9 & 0.0447 & 0.0265 \\
\hline 25th Percentile ${ }^{(a)}$ & 0.112 & 0.011 & 0.005 & -0.001 & 0.099 & 0.005 & 0.004 & -0.0004 \\
\hline 75th Percentile (a) $^{(2)}$ & 0.647 & 0.055 & 0.035 & 0.014 & 0.439 & 0.030 & 0.019 & 0.013 \\
\hline 95th Percentile & 16.3 & 0.254 & 0.107 & 0.019 & 1.19 & 0.975 & 0.032 & 0.024 \\
\hline $\mathrm{N}^{(\mathrm{b})}$ & 96 & 155 & 39 & 22 & 101 & 157 & 51 & 36 \\
\hline $\mathrm{N}$ above detection ${ }^{(\mathrm{c})}$ & 91 & 102 & 18 & 1 & 82 & 75 & 10 & 0 \\
\hline
\end{tabular}

(a) Fifty percent of the data occurs between these two endpoints.

(b) Number of samples.

(c) Number of samples above the analytical detection limit. 


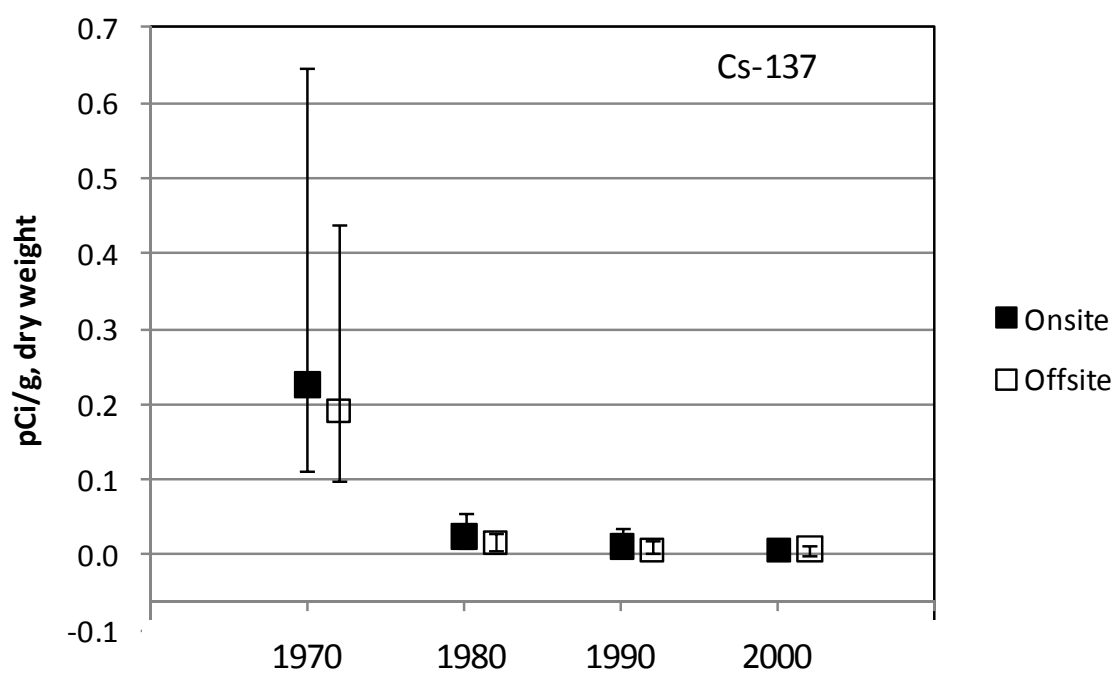

Figure 3.5. Median Cesium-137 Concentrations (pCi/g dry weight) in Vegetation Samples Collected from Onsite (i.e., 100, 200, 300, 400, and 600 Areas) and Offsite (i.e., perimeter, nearby, and distant) Areas by Decade. Error bars encompass $50 \%$ of the data around the median.

\subsection{Strontium-90}

Strontium-90 is a beta-emitting radionuclide with a half-life of 28.8 years. Similar to cesium-137, strontium-90 is a major component in spent nuclear fuel and the wastes associated with processing the fuel and reactor operations (Peterson et al.

- Spatially, soil and vegetation samples collected onsite near the 200 Areas had the highest on-site concentrations of strontium-90. Onsite concentrations exceed those at offsite locations.

- Concentrations were the highest in the 1980s; during that period, over $90 \%$ of the onsite soil samples and $92 \%$ of onsite vegetation samples had concentrations above the MDA. Since 2000 , only $41 \%$ of soil samples and $4 \%$ of the vegetation samples were above the MDA.

- The $95^{\text {th }}$ percentile concentrations for strontium-90 in soil samples exceeded benchmarks and site administrative screening levels at both onsite and offsite regions during the 1970s through the 1990s (see Section 3.7).
2007). Sources of strontium-90 also include fallout from past atmospheric nuclear weapons testing and the Chernobyl accident in 1986. Strontium-90 loosely adheres to soil particles; however, it is highly mobile and soluble in water. It can be absorbed by plants either through the foliage or through absorption by plant roots and translocation (Jones and Haghiri 1962).

The mean background strontium-90 concentration in Hanford surface soils is $0.08 \mathrm{pCi} / \mathrm{g}$ (DOE 1996). Over $80 \%$ of soil samples had concentrations above the analytical detection limit; $90 \%$ of the vegetation samples had concentrations above the MDA.

\subsubsection{Soil}

Soil samples analyzed for strontium-90 were collected yearly between 1971 and 1994 and then in 1997, 1998, 2000-2002, 2004-2006, and 2008. The maximum strontium-90 concentration detected in soil samples was $3.06( \pm 0.13) \mathrm{pCi} / \mathrm{g}$ dry weight from a sample collected in 2001 in the 200 Area. 
Spatially, strontium-90 concentrations in soil samples from onsite areas were significantly higher than those in samples from offsite areas $(P<0.0001)$ (Table 3.14). The mean concentration for onsite soil samples was $0.27 \mathrm{pCi} / \mathrm{g}$ compared to $0.12 \mathrm{pCi} / \mathrm{g}$ for samples collected in offsite locations. The percentage of samples with concentrations above the detection limit ranged from $73 \%$ to $83 \%$ for samples collected at offsite locations to $90 \%$ for onsite samples.

Table 3.14. Strontium- 90 Concentration (pCi/g dry weight) in Soil Samples (1971 through 2008) Collected from the Hanford Site (onsite) and at Various Distances from the Site

\begin{tabular}{|c|c|c|c|c|}
\hline Statistics & Onsite & Perimeter & Nearby & Distant \\
\hline Median & 0.153 & 0.063 & 0.121 & 0.075 \\
\hline Mean & 0.269 & 0.114 & 0.161 & 0.117 \\
\hline Standard Deviation & 0.380 & 0.213 & 0.163 & 0.195 \\
\hline Minimum & -0.0277 & -0.0436 & -0.0058 & -0.0138 \\
\hline Maximum & 3.06 & 2.31 & 0.923 & 1.61 \\
\hline 25th Percentile ${ }^{(a)}$ & 0.065 & 0.020 & 0.043 & 0.029 \\
\hline 75th Percentile ${ }^{(a)}$ & 0.313 & 0.129 & 0.212 & 0.128 \\
\hline 95th Percentile & 0.82 & 0.350 & 0.432 & 0.311 \\
\hline $\mathrm{N}^{(\mathrm{b})}$ & 408 & 360 & 78 & 78 \\
\hline $\mathrm{N}$ above detection ${ }^{(\mathrm{c})}$ & 368 & 264 & 65 & 63 \\
\hline
\end{tabular}

(a) Fifty percent of the data occurs between these two endpoints.

(b) Number of samples.

(c) Number of samples above the analytical detection limit.

For soil samples collected onsite, samples from the 200 Area had significantly higher concentrations than samples from the other areas $(P<0.04)$ (Table 3.15). These concentrations reflect sources of strontium-90 in waste streams associated with chemical processing of irradiated fuel rods in the 200 Area (Peterson and Poston 2000). Ninety-six percent of the samples from the 200 Area were above the detection limit compared to $88 \%$ from the 100 Area and $90 \%$ from the 300 Area.

Strontium-90 concentrations in soil samples decreased significantly both onsite $(P<0.0001$, slope $=-0.0045 \mathrm{pCi} / \mathrm{g} / \mathrm{yr})$ and offsite $(P<0.0001$, slope $=-0.0039 \mathrm{pCi} / \mathrm{g} / \mathrm{yr})$ (Table 3.16; Figure 3.6). The half-life for strontium-90 is around 28 years, with no additional input, we would expect concentrations in soil samples collected in 2000 to be half of that reported in 1970. Comparing mean and median concentrations, those in the 2000s are approximately one-half the concentrations reported in 1970s. However, maximum values have remained similar across the years, with concentrations above $3 \mathrm{pCi} / \mathrm{g}$ dry weight occurring in the 200 Area in 2001. Strontium-90 concentrations from both onsite and offsite locations were higher in the 1980s than in the preceding and following decades. Most of the higher values are associated with samples collected in 1983 (Figure B.5). Both the mean and median values were higher, indicating a shift in the distribution toward higher values. In 1984, strontium-90 concentrations were again similar to those detected in 1982. Analysis without the 1983 data does not change the overall results. Within onsite areas, strontium- 90 concentrations in soil samples from all areas showed a decrease over the 30 years of data collection. 
Table 3.15. Strontium-90 Concentrations in Soil Samples Collected from Various Areas on the Hanford Site Between 1971 and 2008

\begin{tabular}{|c|c|c|c|c|c|c|}
\hline Statistics & 100 Area & 200 Area & 300 Area & 400 Area & 600 Area & Perimeter \\
\hline Median & 0.157 & 0.259 & 0.139 & 0.049 & 0.121 & 0.121 \\
\hline Mean & 0.255 & 0.397 & 0.226 & 0.090 & 0.185 & 0.181 \\
\hline Standard Deviation & 0.380 & 0.481 & 0.272 & 0.119 & 0.270 & 0.206 \\
\hline Minimum & -0.0133 & -0.00193 & -0.0137 & -0.00489 & -0.0277 & 0.00315 \\
\hline Maximum & 2.11 & 3.06 & 1.36 & 0.541 & 1.92 & 1.11 \\
\hline 25th Percentile ${ }^{(a)}$ & 0.069 & 0.121 & 0.064 & 0.032 & 0.038 & 0.064 \\
\hline 75th Percentile ${ }^{(a)}$ & 0.285 & 0.520 & 0.286 & 0.088 & 0.244 & 0.177 \\
\hline 95th Percentile & 0.852 & 1.11 & 0.832 & 0.316 & 0.405 & 0.537 \\
\hline $\mathrm{N}^{(\mathrm{b})}$ & 74 & 148 & 40 & 41 & 64 & 41 \\
\hline $\mathrm{N}$ above detection ${ }^{(\mathrm{c})}$ & 65 & 142 & 36 & 34 & 53 & 38 \\
\hline
\end{tabular}

(a) Fifty percent of the data occurs between these two endpoints.

(b) Number of samples.

(c) Number of samples above the analytical detection limit.

Table 3.16. Strontium- 90 Concentrations in Soil Samples Collected on the Hanford Site Between 1971 and 2008 by Decade

\begin{tabular}{|c|c|c|c|c|c|c|c|c|}
\hline \multirow[b]{2}{*}{ Statistics } & \multicolumn{4}{|c|}{ Onsite } & \multicolumn{4}{|c|}{ Offsite } \\
\hline & 1970 & 1980 & 1990 & 2000 & 1970 & 1980 & 1990 & 2000 \\
\hline Median & 0.160 & 0.279 & 0.105 & 0.049 & 0.088 & 0.128 & 0.076 & 0.026 \\
\hline Mean & 0.252 & 0.386 & 0.212 & 0.102 & 0.140 & 0.214 & 0.091 & 0.036 \\
\hline Standard Deviation & 0.296 & 0.404 & 0.382 & 0.353 & 0.146 & 0.304 & 0.062 & 0.046 \\
\hline Minimum & 0.00225 & 0.00315 & 0.0135 & -0.0277 & 0 & 0 & 0.0126 & -0.0436 \\
\hline Maximum & 2.11 & 2.72 & 2.7 & 3.06 & 0.777 & 2.31 & 0.348 & 0.224 \\
\hline 25th Percentile ${ }^{(\mathrm{a})}$ & 0.066 & 0.140 & 0.069 & 0.015 & 0.027 & 0.075 & 0.046 & 0.003 \\
\hline 75th Percentile ${ }^{(a)}$ & 0.316 & 0.495 & 0.194 & 0.092 & 0.217 & 0.248 & 0.122 & 0.062 \\
\hline 95th Percentile & 0.757 & 1.130 & 0.577 & 0.228 & 0.380 & 0.646 & 0.204 & 0.136 \\
\hline $\mathrm{N}^{(\mathrm{b})}$ & 101 & 157 & 75 & 75 & 100 & 172 & 57 & 187 \\
\hline $\mathrm{N}$ above detection ${ }^{(\mathrm{c})}$ & 100 & 155 & 75 & 38 & 97 & 168 & 57 & 70 \\
\hline
\end{tabular}

\footnotetext{
(a) Fifty percent of the data occurs between these two endpoints.

(b) Number of samples.

(c) Number of samples above the analytical detection limit.
} 


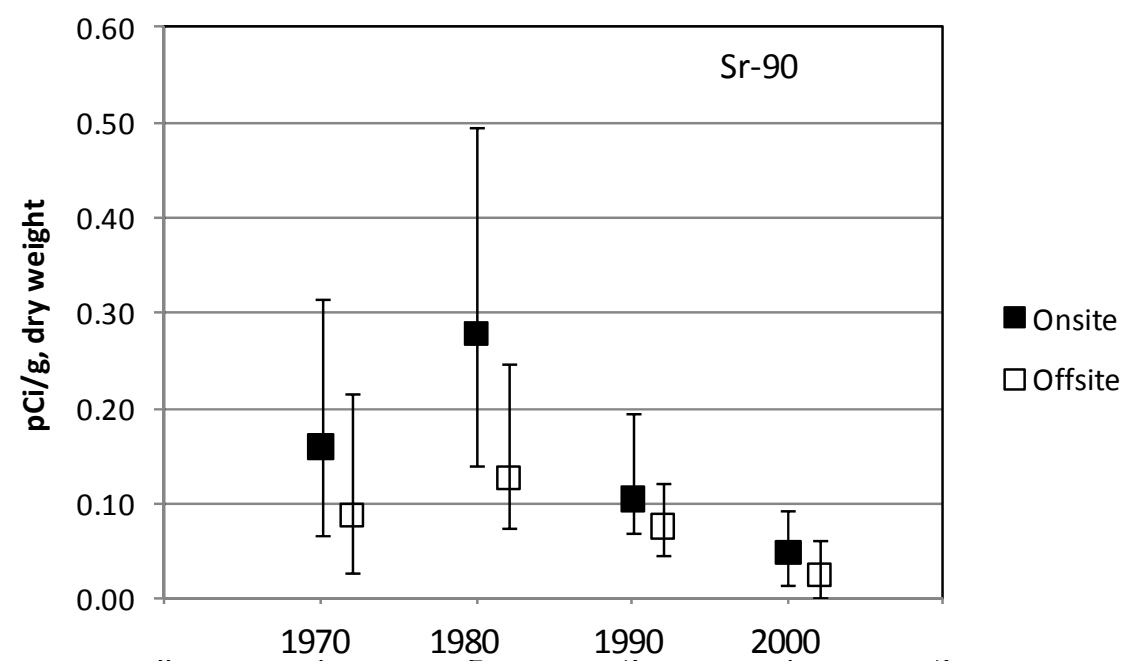

Figure 3.6. Median Strontium-90 Concentrations (pCi/g dry weight) in Soil Samples Collected from Onsite (i.e., 100, 200, 300, 400, and 600 Areas) and Offsite (i.e., perimeter, nearby, and distant) Areas by Decade. Error bars encompass $50 \%$ of the data around the median.

\subsubsection{Vegetation}

Vegetation samples were routinely analyzed for strontium-90 from 1971 through 1994, 1997, 1998, $2000,2001,2004$, and 2008. These samples were analyzed for spatial and temporal differences. The maximum strontium-90 concentration in a vegetation sample was $8.22( \pm 0.09) \mathrm{pCi} / \mathrm{g}$ dry weight collected near the 200 Area in 1986. It should be noted that special sampling of shoreline vegetation along the $100-\mathrm{N}$ shoreline (Antonio et al. 1993) found much greater concentrations of strontium-90 along the 100-N shoreline than concentrations observed in routine upland vegetation samples.

Strontium-90 concentrations in vegetation samples were significantly different $(P<0.001)$ between regions with onsite samples having the highest mean and median concentrations (Table 3.17). Median concentrations of strontium-90 from vegetation samples collected at offsite perimeter and nearby locations were similar and higher than those collected from distant sites. The percentage of samples having concentrations above the MDA ranged from $78 \%$ for distant samples to $92 \%$ for onsite samples.

Within onsite areas, strontium-90 concentrations in vegetation samples were significantly different $(P<0.02)$. The highest strontium-90 concentrations were in vegetation samples collected near the 200 Area compared to concentrations in samples from other onsite areas (Table 3.18). This spatial trend is expected because fuel reprocessing occurred in the 200 Area and is consistent with observations on soil strontium-90 concentrations.

Concentrations in vegetation samples followed a similar temporal trend as the soil samples, with onsite concentrations increasing between the 1970s and 1980s and then decreasing between the 1980s and 1990s) (Table 3.18; Figure 3.7). The onsite trend was not significant $(P=0.074$, slope $=-0.0007$ $\mathrm{pCi} / \mathrm{g} / \mathrm{yr})$ over the period while offsite concentrations showed a significant decline $(P=<0.0001$, slope $=-0.0014 \mathrm{pCi} / \mathrm{g} / \mathrm{yr})$. 
Table 3.17. Strontium-90 Concentration (pCi/g dry weight) in Vegetation Samples (1971 through 2008) Collected on the Hanford Site (onsite) and at Various Distances from the Hanford Site

\begin{tabular}{|c|c|c|c|c|}
\hline Statistics & Onsite & Perimeter & Nearby & Distant \\
\hline Median & 0.066 & 0.046 & 0.046 & 0.030 \\
\hline Mean & 0.165 & 0.080 & 0.075 & 0.053 \\
\hline Standard Deviation & 0.518 & 0.158 & 0.121 & 0.103 \\
\hline Minimum & -0.032 & -0.0185 & -0.0138 & -0.00148 \\
\hline Maximum & 8.22 & 1.65 & 0.847 & 0.74 \\
\hline 25th Percentile ${ }^{(a)}$ & 0.032 & 0.023 & 0.027 & 0.013 \\
\hline 75th Percentile ${ }^{(a)}$ & 0.142 & 0.073 & 0.073 & 0.053 \\
\hline 95th Percentile & 0.534 & 0.217 & 0.182 & 0.179 \\
\hline $\mathrm{N}^{(\mathrm{b})}$ & 306 & 213 & 64 & 54 \\
\hline $\mathrm{N}$ above detection ${ }^{(\mathrm{c})}$ & 281 & 197 & 52 & 42 \\
\hline
\end{tabular}

(a) Fifty percent of the data occurs between these two endpoints.

(b) Number of samples.

(c) Number of samples above the analytical detection limit.

Table 3.18. Strontium- 90 Concentration (pCi/g dry weight) in Vegetation Samples (1971 through 2008) Collected from Various Areas on the Hanford Site

\begin{tabular}{|c|c|c|c|c|c|c|}
\hline Statistics & 100 Area & 200 Area & 300 Area & 400 Area & 600 Area & Perimeter \\
\hline Median & 0.042 & 0.120 & 0.037 & 0.044 & 0.041 & 0.058 \\
\hline Mean & 0.111 & 0.271 & 0.100 & 0.174 & 0.087 & 0.087 \\
\hline Standard Deviation & 0.306 & 0.808 & 0.178 & 0.376 & 0.114 & 0.124 \\
\hline Minimum & -0.009 & 0.00814 & 0.00531 & 0.00669 & -0.032 & 0.00982 \\
\hline Maximum & 2.21 & 8.22 & 0.934 & 1.68 & 0.541 & 0.716 \\
\hline 25th Percentile ${ }^{(a)}$ & 0.015 & 0.063 & 0.023 & 0.024 & 0.027 & 0.032 \\
\hline 75th Percentile ${ }^{(a)}$ & 0.101 & 0.240 & 0.102 & 0.105 & 0.093 & 0.087 \\
\hline 95th Percentile & 0.367 & 0.893 & 0.478 & 1.180 & 0.413 & 0.207 \\
\hline $\mathrm{N}^{(\mathrm{b})}$ & 53 & 107 & 34 & 27 & 53 & 32 \\
\hline $\mathrm{N}$ above detection ${ }^{(\mathrm{c})}$ & 43 & 104 & 31 & 27 & 45 & 31 \\
\hline
\end{tabular}

(a) Fifty percent of the data occurs between these two endpoints.

(b) Number of samples.

(c) Number of samples above the analytical detection limit. 
Table 3.19. Strontium-90 Concentrations (pCi/g dry weight) in Vegetation Samples (1971 through 2001) Collected On and Around the Hanford Site by Decade

\begin{tabular}{|c|c|c|c|c|c|c|c|c|}
\hline \multirow[b]{2}{*}{ Statistics } & \multicolumn{4}{|c|}{ Onsite } & \multicolumn{4}{|c|}{ Offsite } \\
\hline & 1970 & 1980 & 1990 & 2000 & 1970 & 1980 & 1990 & 2000 \\
\hline Median & 0.065 & 0.084 & 0.037 & 0.014 & 0.058 & 0.047 & 0.026 & 0.015 \\
\hline Mean & 0.109 & 0.224 & 0.147 & 0.020 & 0.097 & 0.081 & 0.052 & 0.020 \\
\hline $\begin{array}{l}\text { Standard } \\
\text { Deviation }\end{array}$ & 0.132 & 0.703 & 0.363 & 0.028 & 0.127 & 0.176 & 0.107 & 0.025 \\
\hline Minimum & 0.00669 & 0.00801 & 0.00119 & -0.032 & 0 & -0.0063 & 0.00207 & -0.0185 \\
\hline Maximum & 0.726 & 8.220 & 2.210 & 0.094 & 0.847 & 1.650 & 0.740 & 0.087 \\
\hline 25th Percentile ${ }^{(a)}$ & 0.032 & 0.041 & 0.015 & 0.004 & 0.031 & 0.028 & 0.014 & 0.001 \\
\hline 75th Percentile ${ }^{(a)}$ & 0.142 & 0.177 & 0.118 & 0.037 & 0.118 & 0.067 & 0.045 & 0.035 \\
\hline 95th Percentile & 0.424 & 0.905 & 0.541 & 0.053 & 0.255 & 0.179 & 0.161 & 0.064 \\
\hline $\mathrm{N}^{(\mathrm{b})}$ & 95 & 151 & 39 & 21 & 100 & 145 & 51 & 35 \\
\hline $\begin{array}{l}\mathrm{N} \text { above } \\
\text { detection }^{(\mathrm{c})}\end{array}$ & 94 & 149 & 37 & 1 & 99 & 142 & 49 & 1 \\
\hline
\end{tabular}

(a) Fifty percent of the data occurs between these two endpoints.

(b) Number of samples.

(c) Number of samples above the analytical detection limit.

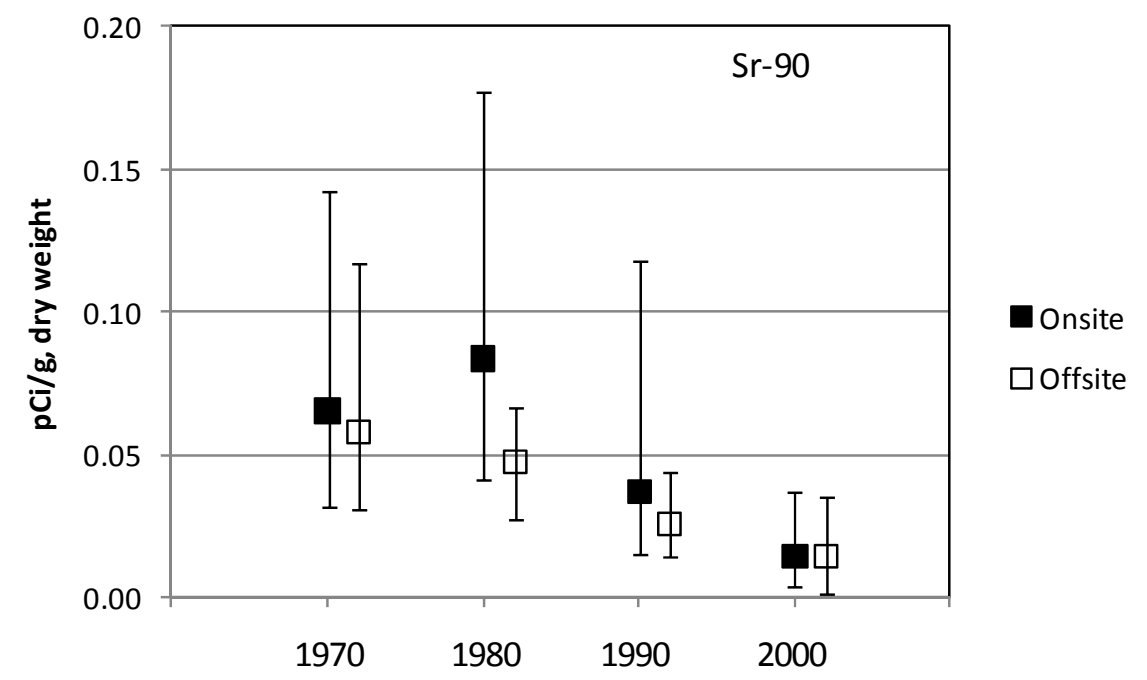

Figure 3.7. Median Strontium- 90 Concentrations (pCi/g dry weight) in Vegetation Samples Collected from Onsite (i.e., 100, 200, 300, 400, and 600 Areas) and Offsite (i.e., perimeter, nearby, and distant) Areas by Decade. Error bars encompass $50 \%$ of the data around the median. 


\subsection{Plutonium-238}

Plutonium is essentially a manmade element. Sources of plutonium include atmospheric testing of nuclear weapons, and inadvertent releases at production facilities. One of the main isotopes of plutonium

- Plutonium-238 concentrations were above the analytical detection limits in $55 \%$ of the soil samples and $23 \%$ of the vegetation samples.

- Spatially, the highest concentrations of plutonium-238 in soil and vegetation samples were obtained near the 200 Areas. Onsite concentrations were very similar to those observed at offsite perimeter, nearby, and distant communities.

- Concentrations were the highest in the 1970s; nearly $60 \%$ of the soil samples had concentrations above the detection limit.

- The $95^{\text {th }}$ percentile concentrations for plutonium-238 in soil samples fell below applicable benchmarks and site administrative screening levels at all on and offsite regions during the entire study period (see Section 3.7). is plutonium-238, an alpha-emitting radionuclide with a half-life of 86.4 years.

Average surface soil concentrations from fallout range between 0.01 and $0.1 \mathrm{pCi} / \mathrm{g}$ (Peterson et al. 2007). On the Hanford Site, the mean background level was estimated at $0.002 \mathrm{pCi} / \mathrm{g}$ with a maximum concentration of $0.019 \mathrm{pCi} / \mathrm{g}$ (DOE 1996).

The contractual MDC for plutonium-238 is $0.0006 \mathrm{pCi} / \mathrm{g}$ dry weight for both soil and vegetation samples; for many analyses, the MDA was below the MDC. Approximately $55 \%$ of the soil samples had concentrations of plutonium-238 above the analytical detection limit, while only $23 \%$ of the vegetation samples were above the MDA.

\subsubsection{Soil}

Soil samples analyzed for plutonium-238 were collected annually between 1971 and 1994 and in 1998-2002, 2004-2006, and 2008. The maximum plutonium-238 concentration, 0.0396 $( \pm 0.00308) \mathrm{pCi} / \mathrm{g}$ dry weight, was detected in a soil sample collected in 1990 from the 200 Area.

Plutonium-238 soil concentrations were not significantly different between onsite and offsite sample regions $(P=0.28)$ (Table 3.20). There was a significant difference among offsite locations $(P=0.0009)$ and among onsite locations $(P=0.003)$. For offsite locations, samples from perimeter locations had the highest median concentration; onsite, samples from the 200 and 600 Areas had the highest concentrations (Table 3.21). The 200 Area was the site of fuel reprocessing and production facilities that are the most likely sources of plutonium-238 contamination.

Temporal analysis indicated that plutonium-238 concentrations in both onsite and offsite soil samples have declined significantly since the 1970 s (onsite: $P=0.042$, slope $=-0.000003 \mathrm{pCi} / \mathrm{g} / \mathrm{yr}$; offsite: $P=0.022$, slope $=-0.000006 \mathrm{pCi} / \mathrm{g} / \mathrm{yr}$ ) (Table 3.21; Figure 3.8). Although median levels have dropped over the study period, there has been no appreciable change in the percentage of values exceeding the MDA, which was around $60 \%$ for each decade until the 2000 s when only $41 \%$ of the samples were above the analytical detection limit. The values of the 75th and 95th percentiles have decreased since the 1980s, indicating a narrowing of the distribution of the data (Table 3.22). Plutonium appears to be fairly immobile in soils at the Hanford Site, except at very low pH (Cantrell et al. 2003). Long-term field studies found plutonium-238 concentrations in soils remained constant over time (Hossner et al. 1998). 
Table 3.20. Plutonium-238 Concentrations (pCi/g dry weight) in Soil Samples Collected on the Hanford Site (onsite) and at Various Distances from the Site Between 1971 and 2008

\begin{tabular}{|c|c|c|c|c|}
\hline Statistics & Onsite & Perimeter & Nearby & Distant \\
\hline Median & 0.00041 & 0.00046 & 0.00032 & 0.00020 \\
\hline Mean & 0.00120 & 0.00088 & 0.00084 & 0.00046 \\
\hline Standard Deviation & 0.00309 & 0.00139 & 0.00177 & 0.00085 \\
\hline Minimum & -0.00119 & -0.00101 & -0.00233 & -0.000221 \\
\hline Maximum & 0.0396 & 0.0116 & 0.0106 & 0.00616 \\
\hline 25th Percentile ${ }^{(a)}$ & 0.00015 & 0.00012 & 0.00010 & 0.00009 \\
\hline 75th Percentile ${ }^{(a)}$ & 0.00089 & 0.00111 & 0.00066 & 0.00048 \\
\hline 95th Percentile & 0.00562 & 0.00346 & 0.00500 & 0.00221 \\
\hline $\mathrm{N}^{(\mathrm{b})}$ & 403 & 354 & 78 & 78 \\
\hline $\mathrm{N}$ above detection ${ }^{(\mathrm{c})}$ & 251 & 176 & 41 & 36 \\
\hline
\end{tabular}

(a) Fifty percent of the data occurs between these two endpoints.

(b) Number of samples.

(c) Number of samples above the analytical detection limit.

Table 3.21. Plutonium- 238 Concentrations (pCi/g dry weight) in Soil Samples Collected in Different Areas on the Hanford Site (onsite) Between 1971 and 2008

\begin{tabular}{|c|c|c|c|c|c|c|}
\hline Statistics & 100 Area & 200 Area & 300 Area & 400 Area & 600 Area & Perimeter \\
\hline Median & 0.00039 & 0.00049 & 0.00040 & 0.00014 & 0.00048 & 0.00031 \\
\hline Mean & 0.00058 & 0.00199 & 0.00058 & 0.00052 & 0.00102 & 0.00103 \\
\hline Standard Deviation & 0.00087 & 0.00471 & 0.00072 & 0.00155 & 0.00142 & 0.00193 \\
\hline Minimum & -0.00014 & -0.000735 & -0.00015 & -0.000962 & -0.0004 & -0.00119 \\
\hline Maximum & 0.00684 & 0.03960 & 0.00387 & 0.00840 & 0.00562 & 0.00935 \\
\hline 25th Percentile ${ }^{(a)}$ & 0.00023 & 0.00019 & 0.00022 & 0.00002 & 0.00017 & 0.00009 \\
\hline 75th Percentile ${ }^{(a)}$ & 0.00070 & 0.00138 & 0.00066 & 0.00028 & 0.00110 & 0.00135 \\
\hline 95th Percentile & 0.00182 & 0.00913 & 0.00222 & 0.00231 & 0.00490 & 0.00427 \\
\hline $\mathrm{N}^{(\mathrm{b})}$ & 74 & 147 & 37 & 41 & 64 & 40 \\
\hline $\mathrm{N}$ above detection ${ }^{(\mathrm{c})}$ & 49 & 97 & 27 & 15 & 41 & 22 \\
\hline
\end{tabular}

(a) Fifty percent of the data occurs between these two endpoints.

(b) Number of samples.

(c) Number of samples above the analytical detection limit. 
Table 3.22. Plutonium-238 Concentrations (pCi/g dry weight) in Soil Samples Collected On and Around the Hanford Site by Decade

\begin{tabular}{|c|c|c|c|c|c|c|c|c|}
\hline \multirow[b]{2}{*}{ Statistics } & \multicolumn{4}{|c|}{ Onsite } & \multicolumn{4}{|c|}{ Offsite } \\
\hline & 1970 & 1980 & 1990 & 2000 & 1970 & 1980 & 1990 & 2000 \\
\hline Median & 0.00071 & 0.00043 & 0.00033 & 0.00033 & 0.00087 & 0.00034 & 0.00034 & 0.00031 \\
\hline Mean & 0.00171 & 0.00122 & 0.00111 & 0.00057 & 0.00155 & 0.00059 & 0.00061 & 0.00064 \\
\hline Standard Deviation & 0.00243 & 0.00312 & 0.00473 & 0.00114 & 0.00222 & 0.00101 & 0.00098 & 0.00103 \\
\hline Minimum & -0.00119 & -0.000962 & -0.00046 & -0.00075 & -0.00101 & -0.00073 & -0.0007 & -0.00233 \\
\hline Maximum & 0.00974 & 0.0308 & 0.0396 & 0.00684 & 0.0116 & 0.00728 & 0.00616 & 0.00643 \\
\hline 25th Percentile ${ }^{(a)}$ & 0.00014 & 0.00017 & 0.00016 & 0.00010 & 0.00013 & 0.00011 & 0.00015 & 0.00007 \\
\hline 75th Percentile ${ }^{(a)}$ & 0.00222 & 0.00089 & 0.00052 & 0.00056 & 0.00190 & 0.00075 & 0.00067 & 0.00081 \\
\hline 95th Percentile & 0.00803 & 0.00574 & 0.00329 & 0.00280 & 0.00627 & 0.00198 & 0.00244 & 0.00291 \\
\hline $\mathrm{N}^{(\mathrm{b})}$ & 101 & 155 & 72 & 75 & 102 & 171 & 52 & 185 \\
\hline $\mathrm{N}$ above detection ${ }^{(\mathrm{c})}$ & 66 & 97 & 52 & 36 & 54 & 91 & 38 & 70 \\
\hline
\end{tabular}

(a) Fifty percent of the data occurs between these two endpoints.

(b) Number of samples.

(c) Number of samples above the analytical detection limit.

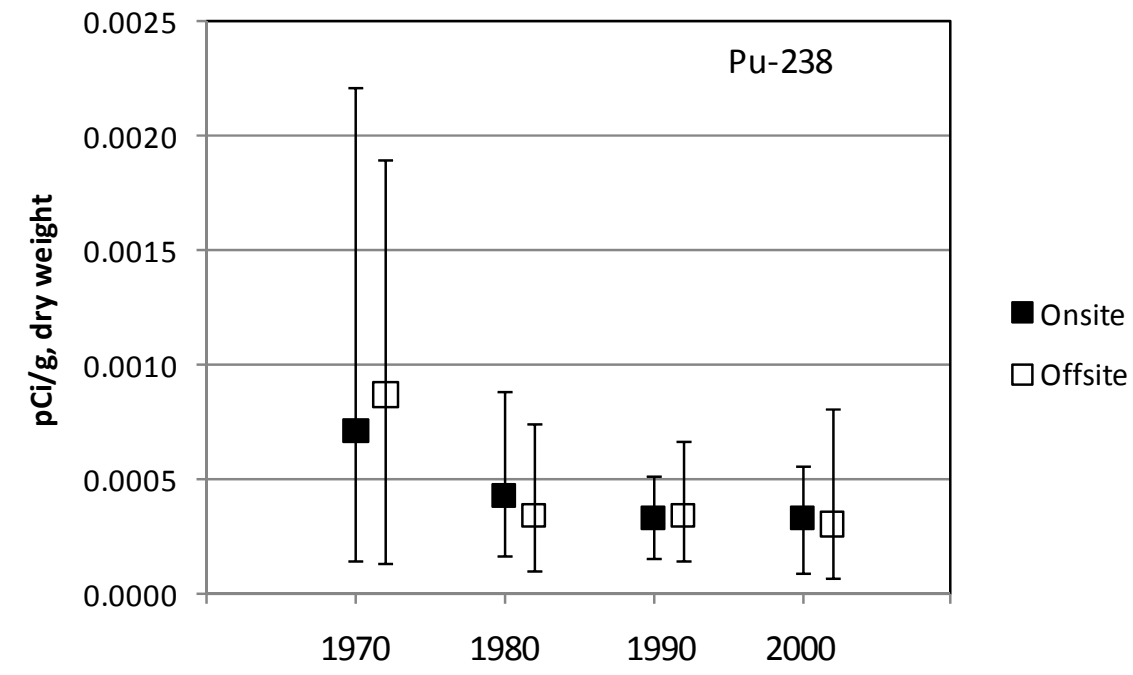

Figure 3.8. Median Plutonium-238 Concentrations (pCi/g dry weight) in Soil Samples Collected from Onsite (i.e., 100, 200, 300, 400, and 600 Areas) and Offsite (i.e., perimeter, nearby, and distant) Areas by Decade. Error bars encompass $50 \%$ of the data around the median.

\subsubsection{Vegetation}

Vegetation samples for plutonium-238 analyses were collected annually between 1971 and 1994 and in 1998, 2000, 2001, 2004, and 2008. Plutonium-238 contamination of vegetation occurs primarily through dry deposition on the foliage. The likely source is either recently released plutonium or resuspension of contaminated soils. When plants accumulate plutonium from the soil, Wildung and Garland (1974) found that the plutonium remained concentrated in the roots and appeared to be translocated downward in the plant. 
The maximum plutonium-238 concentration in samples evaluated for this report was 0.064 $( \pm 0.028) \mathrm{pCi} / \mathrm{g}$ dry weight in a sample collected in 1977 at a perimeter location. Around $23 \%$ of the samples had concentrations above the analytical detection limit

There was no statistically significant difference in concentrations of plutonium-238 from vegetation samples collected on and off the Hanford Site (Table 3.23) $(P=0.145)$. The statistics for plutonium-238 concentrations in vegetation indicates that most of the data are below the detection limits, with a few samples from each region exceeding that limit (i.e., $25 \%$ for samples collected onsite, $23 \%$ for offsite perimeter and nearby samples, and $9 \%$ for distant samples). Onsite, the highest concentrations were from samples collected in the 200 Areas, while the 600 Area had the lowest mean concentrations (Table 3.24).

Table 3.23. Plutonium-238 Concentrations (pCi/g dry weight) in Vegetation Samples Collected on the Hanford Site (onsite) and at Various Distances from the Site Between 1971 and 2008

\begin{tabular}{|c|c|c|c|c|}
\hline Statistics & Onsite & Perimeter & Nearby & Distant \\
\hline Median & 0.00006 & 0.00002 & 0.00005 & 0.00003 \\
\hline Mean & 0.00066 & 0.00005 & -0.00364 & 0.00014 \\
\hline Standard Deviation & 0.00325 & 0.01741 & 0.03703 & 0.00114 \\
\hline Minimum & -0.00439 & -0.233 & -0.294 & -0.00238 \\
\hline Maximum & 0.0361 & 0.0642 & 0.0243 & 0.00764 \\
\hline 25th Percentile ${ }^{(a)}$ & 0.000000 & -0.00001 & 0.00000 & 0.00000 \\
\hline 75th Percentile ${ }^{(a)}$ & 0.00021 & 0.00027 & 0.00018 & 0.00007 \\
\hline 95th Percentile & 0.00410 & 0.00524 & 0.00390 & 0.00030 \\
\hline $\mathrm{N}^{(\mathrm{b})}$ & 297 & 204 & 64 & 53 \\
\hline $\mathrm{N}$ above detection ${ }^{(\mathrm{c})}$ & 73 & 47 & 15 & 5 \\
\hline
\end{tabular}

(a) Fifty percent of the data occurs between these two endpoints.

(b) Number of samples.

(c) Number of samples above the analytical detection limit.

Table 3.24. Plutonium-238 Concentrations (pCi/g dry weight) in Vegetation Samples Collected in Different Areas on the Hanford Site (onsite) Between 1971 and 2008

\begin{tabular}{|c|c|c|c|c|c|c|}
\hline Statistics & 100 Area & 200 Area & 300 Area & 400 Area & 600 Area & Perimeter \\
\hline Median & 0.00004 & 0.00012 & 0.00005 & 0.00003 & 0.00003 & 0.00005 \\
\hline Mean & 0.00009 & 0.00097 & 0.00026 & 0.00053 & 0.00023 & 0.00185 \\
\hline Standard Deviation & 0.00067 & 0.00343 & 0.00069 & 0.00360 & 0.00131 & 0.00690 \\
\hline Minimum & -0.00147 & -0.00233 & -0.000935 & -0.00439 & -0.00198 & -0.00193 \\
\hline Maximum & 0.00439 & 0.0236 & 0.00272 & 0.0159 & 0.00694 & 0.0361 \\
\hline 25th Percentile ${ }^{(a)}$ & -0.00001 & 0.00001 & 0.00000 & -0.00048 & -0.00001 & 0.00000 \\
\hline 75th Percentile ${ }^{(a)}$ & 0.00013 & 0.00054 & 0.00021 & 0.00020 & 0.00011 & 0.00053 \\
\hline 95th Percentile & 0.00041 & 0.00453 & 0.00175 & 0.00604 & 0.00210 & 0.01130 \\
\hline $\mathrm{N}^{(\mathrm{b})}$ & 53 & 105 & 31 & 25 & 53 & 30 \\
\hline $\mathrm{N}$ above detection ${ }^{(\mathrm{c})}$ & 6 & 33 & 10 & 5 & 11 & 8 \\
\hline
\end{tabular}

(a) Fifty percent of the data occurs between these two endpoints.

(b) Number of samples.

(c) Number of samples above the analytical detection limit. 
The overall temporal trend in the concentration of plutonium-238 in vegetation was not significant (onsite: $P=0.21$; offsite: $P=0.96$ ). However, there was a substantial decrease in concentrations between the 1970s and 1980s (Table 3.25; Figure 3.9). The change appears due to a decrease in the number of samples with high concentrations; note the maximum concentration decreases with time, as do both the 75th and 95th percentiles. As with cobalt-60, the temporal trend suggests that plutonium-238 concentration in vegetation has stabilized since the 1980s. There was a strong time dependence on the number of samples above the MDA. About 50\% of the samples from the $1970 \mathrm{~s}$ had concentrations above the MDA compared to around $10 \%$ in the 1980 s and 1990 s to $5 \%$ in 2000.

Table 3.25. Plutonium-238 Concentrations (pCi/g dry weight) in Vegetation Samples Collected On and Around the Hanford Site by Decade

\begin{tabular}{|c|c|c|c|c|c|c|c|c|}
\hline \multirow[b]{2}{*}{ Statistics } & \multicolumn{4}{|c|}{ Onsite } & \multicolumn{4}{|c|}{ Offsite } \\
\hline & 1970 & 1980 & 1990 & 2000 & 1970 & 1980 & 1990 & 2000 \\
\hline Median & 0.00041 & 0.00005 & 0.00002 & 0.00005 & 0.00044 & 0.00000 & 0.00003 & 0.00003 \\
\hline Mean & 0.00179 & 0.00010 & 0.00023 & 0.00006 & -0.00260 & 0.00031 & 0.00006 & 0.00004 \\
\hline Standard Deviation & 0.00541 & 0.00087 & 0.00123 & 0.00008 & 0.03840 & 0.00224 & 0.00013 & 0.00006 \\
\hline Minimum & -0.00439 & -0.00147 & -0.00063 & -0.000083 & -0.294 & -0.00156 & -0.00026 & -0.00007 \\
\hline Maximum & 0.0361 & 0.00744 & 0.00733 & 0.000211 & 0.0642 & 0.0162 & 0.000641 & 0.00027 \\
\hline 25th Percentile ${ }^{(a)}$ & 0.00000 & 0.00000 & -0.00001 & 0.00000 & 0.00000 & -0.00003 & -0.00001 & 0.00000 \\
\hline 75th Percentile ${ }^{(a)}$ & 0.00130 & 0.00013 & 0.00008 & 0.00011 & 0.00210 & 0.00006 & 0.00012 & 0.00007 \\
\hline 95th Percentile & 0.01130 & 0.00057 & 0.00073 & 0.00017 & 0.01420 & 0.00131 & 0.00028 & 0.00015 \\
\hline $\mathrm{N}^{(\mathrm{b})}$ & 96 & 144 & 36 & 21 & 101 & 139 & 46 & 35 \\
\hline $\mathrm{N}$ above detection ${ }^{(\mathrm{c})}$ & 50 & 18 & 3 & 2 & 49 & 11 & 6 & 1 \\
\hline
\end{tabular}

(a) Fifty percent of the data occurs between these two endpoints.

(b) Number of samples.

(c) Number of samples above the analytical detection limit.

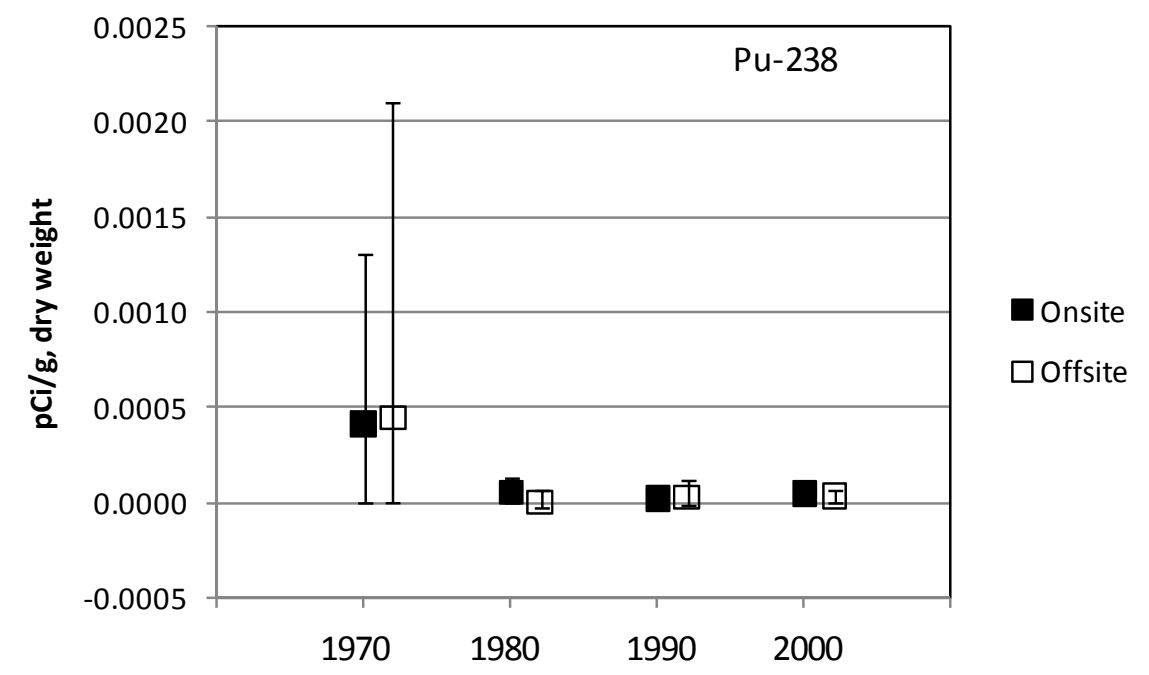

Figure 3.9. Median Plutonium- 238 Concentrations (pCi/g dry weight) in Vegetation Samples Collected from Onsite (i.e., 100, 200, 300, 400, and 600 Areas) and Offsite (i.e., perimeter, nearby, and distant) Areas by Decade. Error bars encompass $50 \%$ of the data around the median. 


\subsection{Plutonium-239/240}

Plutonium-239 is an alpha-emitting radionuclide with a half-life of 24,400 years. Plutonium-240 has a half-life of 6,500 years. Plutonium generally remains in the upper $10 \mathrm{~cm}$ of the soil column, with most of it in the upper $5 \mathrm{~cm}$ (Price 1991). The current contractual MDC for plutonium-239/240 is $0.0004 \mathrm{pCi} / \mathrm{g}$ dry weight for both soil and vegetation samples. Approximately $94 \%$ of the soil samples had concentrations above the MDA, but less than $61 \%$ of the vegetation samples were above the detection limit.

\subsubsection{Soil}

Soil samples for plutonium-239/240 analysis were collected yearly between 1971 and 1994 and in 1998, 2001, 2004-2006, and 2008. The following analyses were based on all these samples. The maximum plutonium-239/240 concentration was detected in a soil sample from the 200 Area in $1979(0.833 \pm 0.022 \mathrm{pCi} / \mathrm{g}$ dry weight $)$.

Plutonium-239/240 concentrations were significantly different across sample regions $(P<0.0001)$, with samples collected onsite having a significantly higher concentration than offsite locations (Table 3.26). The percentage of samples above the MDA was similar for all regions, ranging from $91 \%$ for offsite samples to $97 \%$ for onsite samples.

Table 3.26. Plutonium-239/240 Concentrations (pCi/g dry weight) in Soil Samples Collected on the Hanford Site (onsite) and at Various Distances from the Site Between 1971 and 2008

\begin{tabular}{|c|c|c|c|c|}
\hline Statistics & Onsite & Perimeter & Nearby & Distant \\
\hline Median & 0.0115 & 0.0060 & 0.0098 & 0.0059 \\
\hline Mean & 0.0385 & 0.0085 & 0.0108 & 0.0078 \\
\hline Standard Deviation & 0.1158 & 0.0080 & 0.0070 & 0.0072 \\
\hline Minimum & -0.00017 & -0.00075 & 0.000162 & 0.0000336 \\
\hline Maximum & 0.833 & 0.0427 & 0.0367 & 0.0291 \\
\hline 25th Percentile ${ }^{(a)}$ & 0.0050 & 0.0029 & 0.0061 & 0.0021 \\
\hline 75th Percentile ${ }^{(a)}$ & 0.0198 & 0.0120 & 0.0144 & 0.0106 \\
\hline 95th Percentile & 0.1650 & 0.0255 & 0.0251 & 0.0251 \\
\hline $\mathrm{N}^{(\mathrm{b})}$ & 403 & 353 & 78 & 78 \\
\hline $\mathrm{N}$ above detection ${ }^{(\mathrm{c})}$ & 389 & 321 & 74 & 72 \\
\hline
\end{tabular}

(a) Fifty percent of the data occurs between these two endpoints

(b) Number of samples.

(c) Number of samples above the analytical detection limit. 
For soil samples collected onsite, there was a significant difference in soil concentrations from the various areas $(P<0.0001)$. Samples near the 200 Area had the highest plutonium-239/240

concentrations. Median concentrations were significantly different from concentrations for samples from the 400 and 600 Areas and the onsite perimeter locations (Table 3.27). Of the 23 samples with concentrations greater than $0.1 \mathrm{pCi} / \mathrm{g}, 21$ were from the 200 Area. Concentrations of plutonium-239/240 in soil samples from the 400 Area were significantly lower than those from all other onsite areas. As with plutonium-238, the primary source of plutonium 239/240 would have been from activities in the 200 Area where fuel reprocessing occurred.

Table 3.27. Plutonium-239/240 Concentrations (pCi/g dry weight) in Soil Samples Collected in Different Areas on the Hanford Site (onsite) Between 1971 and 2008

\begin{tabular}{|c|c|c|c|c|c|c|}
\hline Statistics & 100 Area & 200 Area & 300 Area & 400 Area & 600 Area & Perimeter \\
\hline Median & 0.0127 & 0.0168 & 0.0108 & 0.0030 & 0.0108 & 0.0091 \\
\hline Mean & 0.0138 & 0.0847 & 0.0126 & 0.0113 & 0.0109 & 0.0102 \\
\hline Standard Deviation & 0.0120 & 0.1820 & 0.0076 & 0.0319 & 0.0081 & 0.0067 \\
\hline Minimum & 0.000769 & 0.000321 & 0.00043 & 0.000678 & -0.00017 & 0.00112 \\
\hline Maximum & 0.0928 & 0.833 & 0.0278 & 0.165 & 0.0419 & 0.0329 \\
\hline 25th Percentile ${ }^{(a)}$ & 0.0069 & 0.0088 & 0.0064 & 0.0021 & 0.0042 & 0.0050 \\
\hline 75th Percentile ${ }^{(a)}$ & 0.0166 & 0.0314 & 0.0177 & 0.0054 & 0.0167 & 0.0139 \\
\hline 95th Percentile & 0.0271 & 0.5610 & 0.0254 & 0.0243 & 0.0231 & 0.0209 \\
\hline $\mathrm{N}^{(\mathrm{b})}$ & 74 & 147 & 37 & 41 & 64 & 40 \\
\hline $\mathrm{N}$ above detection ${ }^{(\mathrm{c})}$ & 72 & 142 & 36 & 38 & 61 & 40 \\
\hline
\end{tabular}

(a) Fifty percent of the data occurs between these two endpoints.

(b) Number of samples.

(c) Number of samples above the analytical detection limit.

Temporally, soil plutonium 239/240 concentrations decreased both onsite and offsite. The onsite decrease was nominally not significant with a p-value slightly above the 0.05 significance level $(P=0.075)$, while the offsite decrease was significant $(P<0.0001)$ (Table 3.28; Figure 3.10). Concentrations offsite have decreased faster than those onsite (slope: onsite $=-0.00003 \mathrm{pCi} / \mathrm{g} / \mathrm{yr}$, offsite $=-0.00013 \mathrm{pCi} / \mathrm{g} / \mathrm{yr})$ (Figure 3.10).

\subsubsection{Vegetation}

Sampling for plutonium 239/240 in vegetation occurred yearly between 1973 and 1994 and in 1998, 2000, 2001, 2004, and 2008. The maximum plutonium-239/240 concentration in vegetation was 0.148 $( \pm 0.012) \mathrm{pCi} / \mathrm{g}$ dry weight, in a sample from the ALE Reserve collected in 1980 . About $61 \%$ of the vegetation samples had concentrations above the MDA for plutonium-239/240.

Plutonium-239/240 concentrations were significantly higher in vegetation samples from onsite locations compared to samples from those offsite $(P<0.0001)$ (Table 3.29). From 55\% of offsite to 67\% of the onsite samples had concentrations above the MDA. Offsite concentrations decreased with increasing distance from the site, and the number of samples with concentrations above the MDA also decreased from $58 \%$ for perimeter samples to $43 \%$ for distant samples. 
Table 3.28. Plutonium-239/240 Concentrations (pCi/g dry weight) in Soil Samples Collected On and Around the Hanford Site by Decade

\begin{tabular}{|c|c|c|c|c|c|c|c|c|}
\hline \multirow[b]{2}{*}{ Statistics } & \multicolumn{4}{|c|}{ Onsite } & \multicolumn{4}{|c|}{ Offsite } \\
\hline & 1970 & 1980 & 1990 & 2000 & 1970 & 1980 & 1990 & 2000 \\
\hline Median & 0.0129 & 0.0145 & 0.0091 & 0.0075 & 0.0081 & 0.0088 & 0.0072 & 0.0040 \\
\hline Mean & 0.0335 & 0.0489 & 0.0389 & 0.0232 & 0.0107 & 0.0109 & 0.0087 & 0.0057 \\
\hline $\begin{array}{l}\text { Standard } \\
\text { Deviation }\end{array}$ & 0.1038 & 0.1394 & 0.1139 & 0.0699 & 0.0085 & 0.0084 & 0.0065 & 0.0058 \\
\hline Minimum & -0.00017 & 0.000321 & 0.000379 & 0.000115 & -0.00018 & 0.000347 & $3.36 \mathrm{E}-05$ & -0.00075 \\
\hline Maximum & 0.833 & 0.831 & 0.656 & 0.523 & 0.0427 & 0.0425 & 0.0291 & 0.0353 \\
\hline 25th Percentile ${ }^{(a)}$ & 0.0057 & 0.0070 & 0.0048 & 0.0028 & 0.0041 & 0.0040 & 0.0040 & 0.0015 \\
\hline 75th Percentile ${ }^{(a)}$ & 0.0198 & 0.0231 & 0.0162 & 0.0167 & 0.0157 & 0.0155 & 0.0115 & 0.0078 \\
\hline 95th Percentile & 0.0757 & 0.3370 & 0.2860 & 0.0928 & 0.0252 & 0.0277 & 0.0214 & 0.0145 \\
\hline $\mathrm{N}^{(\mathrm{b})}$ & 101 & 155 & 72 & 75 & 101 & 171 & 52 & 185 \\
\hline $\begin{array}{l}\mathrm{N} \text { above } \\
\text { detection }^{(\mathrm{c})}\end{array}$ & 97 & 152 & 70 & 70 & 97 & 169 & 51 & 150 \\
\hline
\end{tabular}

(a) Fifty percent of the data occurs between these two endpoints.

(b) Number of samples.

(c) Number of samples above the analytical detection limit.

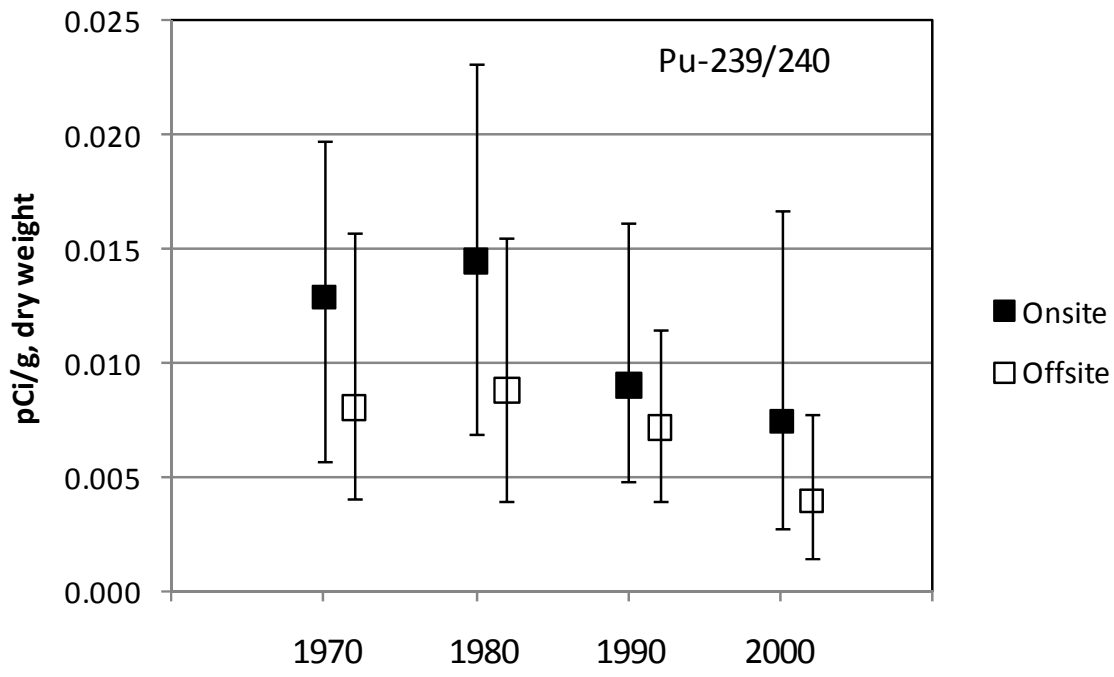

Figure 3.10. Median Plutonium-239/240 Concentrations (pCi/g dry weight) in Soil Samples Collected from Onsite (i.e., 100, 200, 300, 400, and 600 Areas) and Offsite (i.e., perimeter, nearby, and distant) Areas by Decade. Error bars encompass 50\% of the data around the median.

Onsite, there was a significant difference in the concentration of plutonium-239/240 in samples from different areas $(P<0.0001)$ (Table 3.30). Vegetation samples collected near the 200 Area had the highest plutonium-239/240 concentrations, while samples from the other onsite areas had lower and fairly similar median and mean concentrations. The only exception was for results from the onsite perimeter locations, which were similar to the 200 Area; further evaluation indicated the presence of 2 samples (out of 28 samples) with fairly elevated concentrations in the 1970s. The remaining onsite perimeter samples were within the range for the other non-200 Area sample locations. Eighty-one percent of the samples 
from the 200 Area were above the MDA compared to $70 \%$ or less for samples from other onsite areas. These results agree with the known source of the plutonium from processing activities in the 200 Area.

Table 3.29. Plutonium-239/240 Concentrations (pCi/g dry weight) in Vegetation Samples Collected on the Hanford Site (onsite) and at Various Distances from the Site Between 1973 and 2008

\begin{tabular}{|c|c|c|c|c|}
\hline Statistics & Onsite & Perimeter & Nearby & Distant \\
\hline Median & 0.0007 & 0.0004 & 0.0004 & 0.0002 \\
\hline Mean & 0.0024 & 0.0038 & 0.0028 & 0.0004 \\
\hline Standard Deviation & 0.0064 & 0.0146 & 0.0133 & 0.0007 \\
\hline Minimum & -0.0006 & -0.0004 & -0.0001 & 0.0000 \\
\hline Maximum & 0.0633 & 0.148 & 0.102 & 0.0033 \\
\hline 25th Percentile ${ }^{(a)}$ & 0.0002 & 0.0002 & 0.0002 & 0.0001 \\
\hline 75th Percentile ${ }^{(a)}$ & 0.0021 & 0.0016 & 0.0018 & 0.0003 \\
\hline 95th Percentile & 0.0082 & 0.0183 & 0.0048 & 0.0024 \\
\hline $\mathrm{N}^{(\mathrm{b})}$ & 278 & 184 & 58 & 53 \\
\hline $\mathrm{N}$ above detection ${ }^{(\mathrm{c})}$ & 186 & 107 & 31 & 23 \\
\hline
\end{tabular}

(a) Fifty percent of the data occurs between these two endpoints.

(b) Number of samples.

(c) Number of samples above the analytical detection limit.

Table 3.30. Plutonium-239/240 Concentrations (pCi/g dry weight) in Vegetation Samples Collected in Different Areas on the Hanford Site (onsite) Between 1973 and 2008

\begin{tabular}{|c|c|c|c|c|c|c|}
\hline Statistics & 100 Area & 200 Area & 300 Area & 400 Area & 600 Area & Perimeter \\
\hline Median & 0.0002 & 0.0011 & 0.0004 & 0.0007 & 0.0007 & 0.0009 \\
\hline Mean & 0.0010 & 0.0040 & 0.0009 & 0.0011 & 0.0014 & 0.0040 \\
\hline Standard Deviation & 0.0044 & 0.0083 & 0.0012 & 0.0013 & 0.0018 & 0.0102 \\
\hline Minimum & -0.0002 & 0.0000 & 0.0000 & -0.0003 & -0.0006 & -0.0001 \\
\hline Maximum & 0.0316 & 0.0633 & 0.0046 & 0.0051 & 0.0094 & 0.0497 \\
\hline 25th Percentile ${ }^{(a)}$ & 0.0001 & 0.0005 & 0.0001 & 0.0002 & 0.0002 & 0.0003 \\
\hline 75th Percentile ${ }^{(a)}$ & 0.0006 & 0.0042 & 0.0012 & 0.0014 & 0.0023 & 0.0023 \\
\hline 95th Percentile & 0.0014 & 0.0133 & 0.0037 & 0.0041 & 0.0042 & 0.0257 \\
\hline $\mathrm{N}^{(\mathrm{b})}$ & 51 & 97 & 29 & 25 & 48 & 28 \\
\hline $\mathrm{N}$ above detection ${ }^{(\mathrm{c})}$ & 25 & 79 & 18 & 12 & 32 & 20 \\
\hline
\end{tabular}

(a) Fifty percent of the data occurs between these two endpoints.

(b) Number of samples.

(c) Number of samples above the analytical detection limit.

Since 1970, plutonium-239/240 concentrations have decreased significantly in both onsite and offsite vegetation samples, with both median and range of values decreasing (Table 3.31; Figure 3.11). Seventy-four percent of the samples from the 1970s had plutonium-239/240 concentrations above the MDA compared to about $61 \%$ in the $1980 \mathrm{~s}, 48 \%$ in the 1990 s, and $41 \%$ in the samples taken since 2000 . These observations suggest that plutonium-239/240 has become less biologically available, possibly by binding more tightly to the soil or because less plutonium has been released to the atmosphere since the 
shutdown of processing facilities at Hanford and the cessation of atmospheric testing. Because of the relatively long physical half-life of both isotopes, radiological decay is an insignificant consideration.

Table 3.31. Plutonium-239/240 Concentrations (pCi/g dry weight) in Vegetation Samples Collected On and Around the Hanford Site by Decade

\begin{tabular}{lccccccccc}
\hline & \multicolumn{4}{c}{ Onsite } & \multicolumn{5}{c}{ Offsite } \\
\cline { 2 - 9 } \multicolumn{1}{c}{ Statistics } & 1970 & 1980 & 1990 & 2000 & 1970 & 1980 & 1990 & 2000 \\
\hline Median & 0.0021 & 0.0005 & 0.0001 & 0.0002 & 0.0022 & 0.0002 & 0.0002 & 0.0002 \\
Mean & 0.0043 & 0.0017 & 0.0017 & 0.0013 & 0.0042 & 0.0040 & 0.0003 & 0.0004 \\
Standard Deviation & 0.0072 & 0.0060 & 0.0069 & 0.0022 & 0.0070 & 0.0181 & 0.0003 & 0.0006 \\
Minimum & -0.0006 & -0.0003 & -0.0001 & 0.0000 & 0.0000 & -0.0004 & 0.0000 & 0.0000 \\
Maximum & 0.0497 & 0.0633 & 0.0413 & 0.0077 & 0.05 & 0.148 & 0.0013 & 0.0031 \\
25th Percentile & (a) & 0.0010 & 0.0003 & 0.0001 & 0.0001 & 0.0012 & 0.0001 & 0.0001 & 0.0001 \\
75th Percentile & (a) & 0.0042 & 0.0012 & 0.0005 & 0.0013 & 0.0042 & 0.0006 & 0.0003 & 0.0004 \\
95th Percentile & 0.0222 & 0.0044 & 0.0066 & 0.0069 & 0.0183 & 0.0250 & 0.0007 & 0.0013 \\
$\mathrm{~N}^{(\mathrm{b})}$ & 77 & 144 & 36 & 21 & 75 & 139 & 46 & 35 \\
$\mathrm{~N}^{\text {above detection }}{ }^{(\mathrm{c})}$ & 59 & 99 & 16 & 12 & 54 & 73 & 23 & 11 \\
\hline
\end{tabular}

(a) Fifty percent of the data occurs between these two endpoints.

(b) Number of samples.

(c) Number of samples above the analytical detection limit.

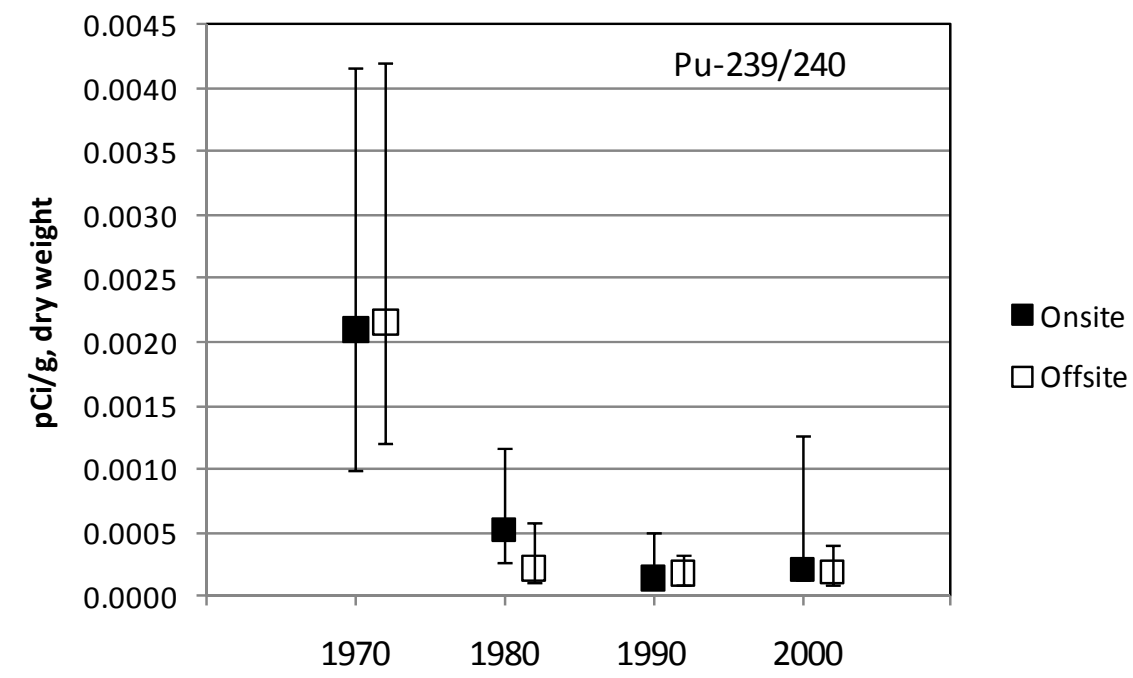

Figure 3.11. Median Plutonium-239/240 Concentrations (pCi/g dry weight) in Vegetation Samples Collected from Onsite (i.e., 100, 200, 300, 400, and 600 Areas) and Offsite (i.e., perimeter, nearby, and distant) Areas by Decade. Error bars encompass $50 \%$ of the data around the median. 


\subsection{Uranium}

Uranium is a naturally occurring radioactive element that contributes to low levels of background radiation. Refined uranium was processed at the Hanford Site into reactor fuel elements for plutonium production. Most of this processing occurred in the 300 Area. There are three natural isotopes of uranium: uranium 234, uranium-235, and

- The evaluation of uranium in soil and vegetation was confounded by the use of different methods over the 35-year study period.

- Because of the different methods used to analyze uranium and the few onsite sample locations near the 300 Area, the distribution statistics for onsite concentrations versus those from offsite were very similar to those observed at offsite perimeter, nearby, and distant communities, with the exception of maximum concentrations.

- Onsite, the highest concentrations of uranium in soil and vegetation samples were obtained near the 300 Area.

- Methods that measured surface-bound uranium (fluorometry and alpha spectroscopy of leached samples) were most efficacious at delineating differences between onsite sampling areas.

- Collectively, maximum observations of uranium in soil occurred in the 1980s.

- The $95^{\text {th }}$ percentile concentrations for all measurements of uranium in soil samples fell below applicable benchmarks and site administrative screening levels for all onsite and offsite areas during the entire study period (see Section 3.7). uranium-238. Uranium-238 comprises $99.3 \%$ of the isotopic abundance of natural uranium, uranium-234 is a decay product of uranium-238, and uranium-235 is a distinct natural isotope with its own decay chain. Uranium-238 has a half-life of 4,510,000,000 years. Uranium isotopes are primarily alphaemitters. Uranium also has the potential to move through the soil column and be available for plant uptake. This analysis will focus on total uranium and uranium-238 as indicative of uranium surveillance results.

The spatial and temporal trend analysis for uranium was complicated by the use of several different analytical and processing methods over the nearly 40 years. In addition, results for some methods were reported as total uranium, while the results from other methods were given as uranium-238. The analyses results will be presented separately for each method.

The contractual MDC for uranium varied with the processing method. For soil samples, total uranium had an MDC of $0.01 \mathrm{pCi} / \mathrm{g}$ dry weight, while the MDC for uranium-238 was $1.0 \mathrm{pCi} / \mathrm{g}$ dry weight for samples analyzed using LEPS and $0.02 \mathrm{pCi} / \mathrm{g}$ dry weight for samples analyzed using alpha spectrometry. The MDC for vegetation samples was $0.01 \mathrm{pCi} / \mathrm{g}$ dry weight for both total uranium (fluorometry) and uranium-238 in samples analyzed using alpha spectrometry.

\subsubsection{Soil}

Soil samples were collected and analyzed for total uranium by fluorometry yearly from 1973 through 1987. After 1987, soil samples analyzed for uranium were reported by isotope, and we will report on uranium-238 results as indicative of all uranium. Isotopic analyses were reported on samples routinely collected from 1987 through 1994 and in 1997, 1998, 2000-2002, 2004-2006, and 2008. Uranium-238 concentrations in soil samples were analyzed with either LEPS or alpha energy analysis. Two processing methods were used for the alpha energy analysis: total sample dissolution (alpha-total) and acid leaching (alpha-acid). Because of differences in analytical methods and expression of results, it is not appropriate 
to compare results from one method to another. Results from the LEPS method and the alpha total dissolution method should be in relative agreement with each other. The fluorometry results when converted to an activity concentration will reflect all decay activity associated with uranium-234, uranium-235, and uranium-238 while the acid-leach results have had only the uranium-238 activity reported. The acidleaching results should be approximately half of the concentration reported for fluorometry.

Samples processed with total sample dissolution had higher uranium-238 concentrations than acidleached samples. The LEPS and alpha-total analysis methods capture all the uranium in a sample while acid leaching captures only surface-deposited uranium-238 or the uranium that is readily leached from the soil particle surface. The acid-leaching process more readily detects releases of uranium into the environment because it inherently carries a lower background component of natural uranium. Because the different processing and analysis methods yield different results, they are discussed separately.

\subsubsection{Total Uranium Fluorometry (1971-1987)}

The concentrations of total uranium in soils were significantly different between onsite and offsite locations $(P=0.0054)$ (Table 3.32). The difference was due to higher concentrations in soils from offsite perimeter locations in the $1980 \mathrm{~s}$. Concentrations in samples from distant locations were significantly lower than concentrations in samples from perimeter locations $(P=0.016)$. The maximum uranium concentration was $5.44( \pm 1.65) \mathrm{pCi} / \mathrm{g}$ dry weight for a sample collected in 1985 from the 300 Area (Table 3.33). All but one soil sample analyzed for total uranium were above the MDA for fluorometry. There were significant differences in the mean concentrations of total uranium among onsite sample location areas. Soil samples from the 300 Area had significantly higher concentrations of uranium than samples from other onsite areas $(P<0.001)$ (Table 3.33). These observations are consistent with the role that the 300 Area played in fuel rod manufacture and testing during plutonium production.

Table 3.32. Total Uranium Concentrations (pCi/g dry weight) in Soil Samples Collected on the Hanford Site (onsite) and at Various Distances from the Site Between 1973 and 1987

\begin{tabular}{|c|c|c|c|c|}
\hline Statistics & Onsite & Perimeter & Near & Distant \\
\hline Median & 0.306 & 0.373 & 0.343 & 0.290 \\
\hline Mean & 0.402 & 0.452 & 0.373 & 0.312 \\
\hline Standard Deviation & 0.482 & 0.261 & 0.164 & 0.138 \\
\hline Minimum & 0.0872 & 0.0451 & 0.0736 & 0.0816 \\
\hline Maximum & 5.44 & 1.42 & 0.914 & 0.722 \\
\hline 25th Percentile ${ }^{(a)}$ & 0.239 & 0.281 & 0.258 & 0.211 \\
\hline 75th Percentile ${ }^{(a)}$ & 0.417 & 0.552 & 0.434 & 0.403 \\
\hline 95th Percentile & 0.756 & 1.13 & 0.684 & 0.516 \\
\hline $\mathrm{N}^{(\mathrm{b})}$ & 204 & 136 & 40 & 28 \\
\hline $\mathrm{N}$ above detection ${ }^{(\mathrm{c})}$ & 204 & 135 & 40 & 28 \\
\hline
\end{tabular}

(a) Fifty percent of the data occurs between these two endpoints.

(b) Number of samples.

(c) Number of samples above the analytical detection limit. 
Table 3.33. Total Uranium Concentrations (pCi/g dry weight) in Soil Samples Collected from Different Areas on the Hanford Site (onsite) Between 1973 and 1987

\begin{tabular}{|c|c|c|c|c|c|c|}
\hline Statistics & 100 Area & 200 Area & 300 Area & 400 Area & 600 Area & Perimeter \\
\hline Median & 0.320 & 0.324 & 0.658 & 0.270 & 0.283 & 0.254 \\
\hline Mean & 0.348 & 0.366 & 1.122 & 0.311 & 0.291 & 0.290 \\
\hline Standard Deviation & 0.154 & 0.167 & 1.382 & 0.143 & 0.108 & 0.155 \\
\hline Minimum & 0.155 & 0.0872 & 0.174 & 0.162 & 0.116 & 0.101 \\
\hline Maximum & 0.893 & 1.03 & 5.44 & 0.851 & 0.650 & 0.798 \\
\hline 25th Percentile ${ }^{(a)}$ & 0.236 & 0.259 & 0.310 & 0.231 & 0.199 & 0.206 \\
\hline 75th Percentile ${ }^{(a)}$ & 0.427 & 0.460 & 1.040 & 0.374 & 0.359 & 0.332 \\
\hline 95th Percentile & 0.529 & 0.715 & 5.440 & 0.489 & 0.420 & 0.679 \\
\hline $\mathrm{N}^{(\mathrm{b})}$ & 24 & 77 & 18 & 25 & 32 & 28 \\
\hline $\mathrm{N}$ above detection ${ }^{(\mathrm{c})}$ & 24 & 77 & 18 & 25 & 32 & 28 \\
\hline
\end{tabular}

(a) Fifty percent of the data occurs between these two endpoints.

(b) Number of samples.

(c) Number of samples above the analytical detection limit.

Temporal differences for total uranium concentrations were significant $(P<0.0001)$. Concentrations of total uranium collected in the 1980 s were significantly higher than concentrations in soil samples collected in the 1970s (Table 3.34).

Table 3.34. Uranium Concentrations (pCi/g dry weight) in Soil Samples Collected On and Around the Hanford Site Between 1970 and 2008 by Decade.

\begin{tabular}{|c|c|c|c|c|c|c|c|}
\hline \multirow[b]{2}{*}{ Statistics } & \multicolumn{2}{|c|}{$\begin{array}{l}\text { Total Uranium } \\
\text { (Fluorometry) }\end{array}$} & \multicolumn{2}{|c|}{$\begin{array}{c}\text { U-238 } \\
\text { (LEPS) }\end{array}$} & \multirow{2}{*}{$\begin{array}{c}\begin{array}{c}\mathrm{U}-238 \\
\text { (Alpha-total) }\end{array} \\
1990\end{array}$} & \multicolumn{2}{|c|}{$\begin{array}{c}\text { U-238 } \\
\text { (Alpha-acid) }\end{array}$} \\
\hline & 1970 & 1980 & 1980 & 1990 & & 1990 & 2000 \\
\hline Median & 0.295 & 0.360 & 0.689 & 0.669 & 0.682 & 0.167 & 0.162 \\
\hline Mean & 0.343 & 0.450 & 0.767 & 0.712 & 0.692 & 0.189 & 0.248 \\
\hline Standard Deviation & 0.210 & 0.448 & 0.372 & 0.254 & 0.129 & 0.080 & 0.266 \\
\hline Minimum & 0.0451 & 0.0816 & 0.141 & 0.154 & 0.460 & 0.0999 & 0.0382 \\
\hline Maximum & 1.27 & 5.44 & 3.25 & 1.45 & 1.02 & 0.441 & 2.88 \\
\hline 25th Percentile ${ }^{(a)}$ & 0.208 & 0.272 & 0.576 & 0.537 & 0.580 & 0.131 & 0.119 \\
\hline 75th Percentile ${ }^{(a)}$ & 0.391 & 0.475 & 0.901 & 0.838 & 0.801 & 0.214 & 0.265 \\
\hline 95th Percentile & 0.703 & 0.924 & 1.350 & 1.160 & 0.905 & 0.355 & 0.613 \\
\hline $\mathrm{N}^{(\mathrm{b})}$ & 156 & 252 & 117 & 65 & 49 & 26 & 262 \\
\hline $\mathrm{N}$ above detection ${ }^{(\mathrm{c})}$ & 155 & 252 & 112 & 62 & 49 & 26 & 245 \\
\hline
\end{tabular}

(a) Fifty percent of the data occurs between these two endpoints.

(b) Number of samples.

(c) Number of samples above the analytical detection limit.

LEPS $=$ Low-energy photon spectrometry. 


\subsubsection{Uranium-238 Low-Energy Photon Spectrometry (1987-1989, 1992-1994, 1999)}

There was no significant difference in uranium-238 concentrations from onsite versus offsite sample regions for soil samples analyzed by LEPS $(P=0.41)$ (Table 3.35). The maximum uranium-238 concentration analyzed using LEPS for a soil sample collected in 1987 near the 300 Area, was 3.25 $( \pm 0.46) \mathrm{pCi} / \mathrm{g}$ dry weight (Table 3.36). Within the onsite operational areas, the 300 Area had the highest concentrations of uranium-238 (Table 3.36). Concentrations were similar for samples collected in the 1980 s compared to those collected in the 1990s (Table 3.34). For samples analyzed using LEPS, 98\% of the samples had concentrations above the MDA for that method.

Table 3.35. Uranium-238 Concentrations (pCi/g dry weight) in Soil Samples Collected on the Hanford Site (onsite) and at Various Distances from the Site Between 1987 and 2008. Samples were analyzed using low-energy photon spectrometry (LEPS), alpha spectrometry with total dissolution (alpha-total) and alpha spectrometry with acid leaching (alpha-acid).

\begin{tabular}{|c|c|c|c|c|c|c|c|c|c|c|}
\hline $\begin{array}{l}\text { Distance } \\
\text { from Site }\end{array}$ & Median & Mean & $\begin{array}{l}\text { Standard } \\
\text { Deviation }\end{array}$ & Minimum & Maximum & $\begin{array}{c}25 \text { th } \\
\text { Percentile }^{(a)}\end{array}$ & $\begin{array}{c}\text { 75th } \\
\text { Percentile }^{(a)}\end{array}$ & $\begin{array}{c}\text { 95th } \\
\text { Percentile }\end{array}$ & $\mathrm{N}^{(\mathrm{b})}$ & $\begin{array}{c}\text { N Above } \\
\text { Detection }^{(\mathrm{c})}\end{array}$ \\
\hline \multicolumn{11}{|c|}{ LEPS $(1987-1989,1992-1994,1999)$} \\
\hline Onsite & 0.666 & 0.740 & 0.366 & 0.315 & 3.25 & 0.529 & 0.867 & 1.180 & 91 & 89 \\
\hline Perimeter & 0.734 & 0.737 & 0.252 & 0.154 & 1.45 & 0.576 & 0.897 & 1.130 & 47 & 45 \\
\hline Near & 0.696 & 0.806 & 0.364 & 0.304 & 1.79 & 0.564 & 1.036 & 1.790 & 16 & 15 \\
\hline Distant & 0.671 & 0.747 & 0.345 & 0.141 & 1.73 & 0.584 & 0.838 & 1.420 & 29 & 26 \\
\hline \multicolumn{11}{|c|}{ Alpha-total (1990-1992) } \\
\hline Onsite & 0.687 & 0.712 & 0.139 & 0.535 & 1.02 & 0.610 & 0.826 & 1.020 & 19 & 19 \\
\hline Perimeter & 0.764 & 0.745 & 0.100 & 0.543 & 0.905 & 0.679 & 0.831 & 0.905 & 17 & 17 \\
\hline Near & 0.594 & 0.593 & 0.061 & 0.526 & 0.658 & 0.542 & 0.644 & 0.658 & 4 & 4 \\
\hline Distant & 0.567 & 0.595 & 0.115 & 0.460 & 0.836 & 0.533 & 0.639 & 0.836 & 9 & 9 \\
\hline \multicolumn{11}{|c|}{ Alpha-acid (1997-2008) } \\
\hline Onsite & 0.145 & 0.227 & 0.186 & 0.0646 & 1.15 & 0.105 & 0.355 & 0.568 & 91 & 86 \\
\hline Perimeter & 0.167 & 0.250 & 0.301 & 0.0526 & 2.88 & 0.134 & 0.213 & 0.663 & 156 & 146 \\
\hline Near & 0.152 & 0.227 & 0.158 & 0.0686 & 0.550 & 0.120 & 0.341 & 0.550 & 18 & 18 \\
\hline Distant & 0.128 & 0.260 & 0.223 & 0.0382 & 0.714 & 0.100 & 0.511 & 0.660 & 23 & 21 \\
\hline
\end{tabular}

(a) Fifty percent of the data occurs between these two endpoints.

(b) Number of samples.

(c) Number of samples above the analytical detection limit.

\subsubsection{Uranium-238 Alpha Energy Analysis (1990-2008)}

Soil samples analyzed by alpha energy analysis were processed by two methods: total dissolution (alpha-total, 1990-1992) and by acid leaching (alpha-acid, 1997-2008). Results from alpha-total dissolution were significantly higher than results from alpha-acid leaching and are most similar to LEPS results for soil.

The total number of samples analyzed using alpha energy was small due to the short time this method was used coupled with a reduction in sampling effort during the 1990s. Consequently, temporal and spatial comparisons are not statistically rigorous. The maximum concentration for a soil sample analyzed using alpha-total was $1.02( \pm 0.099) \mathrm{pCi} / \mathrm{g}$ dry weight for a sample collected in 1991 from near the 300 Area. Concentrations between onsite and offsite regions were not significantly different $(P=0.44)$ 
(Table 3.35), and there were no significant differences $(P=0.43)$ in uranium-238 concentrations between the onsite areas (Table 3.36). All the soil samples analyzed by alpha-total were above the detection limit.

Table 3.36. Uranium- 238 Concentrations ( $\mathrm{pCi} / \mathrm{g}$ dry weight) in Soil Samples Collected from Different Areas on the Hanford Site (onsite) Between 1987 and 2002. Samples were analyzed using low-energy photon spectrometry (LEPS), alpha spectrometry with total dissolution (alphatotal) and alpha spectrometry with acid leaching (alpha-acid).

\begin{tabular}{|c|c|c|c|c|c|c|c|c|c|c|}
\hline $\begin{array}{l}\text { Onsite } \\
\text { Areas }\end{array}$ & Median & Mean & $\begin{array}{c}\text { Standard } \\
\text { Deviation }\end{array}$ & Minimum & Maximum & $\begin{array}{c}25 \text { th } \\
\text { Percentile }^{(a)}\end{array}$ & $\begin{array}{c}\text { 75th } \\
\text { Percentile }^{(a)}\end{array}$ & $\begin{array}{c}\text { 95th } \\
\text { Percentile }\end{array}$ & $\mathrm{N}^{(\mathrm{b})}$ & $\begin{array}{c}\text { N Above } \\
\text { Detection }^{(\mathrm{c})}\end{array}$ \\
\hline \multicolumn{11}{|c|}{ LEPS } \\
\hline 100 Area & 0.789 & 0.812 & 0.292 & 0.354 & 1.45 & 0.640 & 1.040 & 1.310 & 22 & 22 \\
\hline 200 Area & 0.658 & 0.681 & 0.232 & 0.356 & 1.18 & 0.463 & 0.828 & 1.150 & 36 & 36 \\
\hline 300 Area & 0.850 & 1.055 & 0.854 & 0.337 & 3.25 & 0.669 & 0.939 & 3.250 & 9 & 9 \\
\hline 400 Area & 0.561 & 0.645 & 0.202 & 0.449 & 1.12 & 0.540 & 0.722 & 1.120 & 9 & 9 \\
\hline 600 Area & 0.551 & 0.634 & 0.295 & 0.315 & 1.21 & 0.429 & 0.794 & 1.210 & 8 & 6 \\
\hline Perimeter & 0.608 & 0.653 & 0.207 & 0.400 & 1.03 & 0.511 & 0.808 & 1.030 & 7 & 7 \\
\hline \multicolumn{11}{|c|}{ Alpha-total } \\
\hline 100 Area & 0.610 & 0.613 & 0.076 & 0.545 & 0.687 & 0.548 & 0.678 & 0.687 & 4 & 4 \\
\hline 200 Area & 0.687 & 0.726 & 0.138 & 0.535 & 0.957 & 0.638 & 0.834 & 0.957 & 8 & 8 \\
\hline 300 Area & 0.867 & 0.867 & 0.216 & 0.714 & 1.02 & 0.714 & 1.020 & 1.020 & 2 & 2 \\
\hline 400 Area & 0.663 & 0.663 & 0.121 & 0.577 & 0.748 & 0.577 & 0.748 & 0.748 & 2 & 2 \\
\hline 600 Area & 0.751 & 0.751 & 0.193 & 0.614 & 0.887 & 0.614 & 0.887 & 0.887 & 2 & 2 \\
\hline Perimeter & 0.711 & 0.711 & 0.000 & 0.711 & 0.711 & 0.711 & 0.711 & 0.711 & 1 & 1 \\
\hline \multicolumn{11}{|c|}{ Alpha-acid } \\
\hline 100 Area & 0.138 & 0.235 & 0.180 & 0.0832 & 0.657 & 0.110 & 0.420 & 0.512 & 24 & 22 \\
\hline 200 Area & 0.142 & 0.239 & 0.236 & 0.0708 & 1.15 & 0.110 & 0.265 & 0.613 & 26 & 24 \\
\hline 300 Area & 0.258 & 0.305 & 0.168 & 0.0911 & 0.621 & 0.170 & 0.383 & 0.621 & 11 & 10 \\
\hline 400 Area & 0.158 & 0.200 & 0.113 & 0.101 & 0.372 & 0.114 & 0.291 & 0.372 & 8 & 8 \\
\hline 600 Area & 0.119 & 0.162 & 0.142 & 0.0646 & 0.544 & 0.080 & 0.157 & 0.544 & 16 & 16 \\
\hline Perimeter & 0.132 & 0.219 & 0.176 & 0.0774 & 0.481 & 0.091 & 0.402 & 0.481 & 6 & 6 \\
\hline
\end{tabular}

(a) Fifty percent of the data occurs between these two endpoints.

(b) Number of samples.

(c) Number of samples above the analytical detection limit.

The maximum concentration for a soil sample analyzed using alpha-acid processing was $2.88 \mathrm{pCi} / \mathrm{g}$ dry weight for a sample collected from a perimeter location in 2005 (Table 3.35). Overall, there was no apparent difference $(P=0.11)$ in the uranium-238 concentrations between onsite and the offsite sampling regions (Table 3.35) or between onsite areas $(P=0.14)$ (Table 3.36). Temporal trends for the alpha-acid samples indicated a slight increase between the 1990s and current sampling (Table 3.34). This increase is evident primarily in concentrations from onsite locations.

\subsubsection{Vegetation}

Vegetation samples were collected for total uranium analysis (fluorometry) yearly from 1971 through 1992, and for uranium-238 analysis (alpha energy analysis) from 1990 through 1994, and in 1997, 1998, 2000, 2001, 2004, and 2008. Although different methods were used in the analysis for total uranium and uranium-238 in plants, processing methods remained the same; therefore, concentrations from the two analysis methods were comparable. The maximum total uranium concentration in vegetation samples 
was $7.22 \mathrm{pCi} / \mathrm{g}$ dry weight, in a sample from Byers Landing (perimeter) in 1974. This value was an order of magnitude higher than the next-highest concentration of $0.7 \mathrm{pCi} / \mathrm{g}$ dry weight, for a 1971 sample from the Wahluke Slope (perimeter), and was identified as an outlier in 1977 (Miller et al. 1977). That value was not included in this analysis. The maximum uranium-238 concentration was $0.0592( \pm 0.0075) \mathrm{pCi} / \mathrm{g}$ dry weight for a 1991 sample from Moses Lake (distant). Eighty-nine percent of the vegetation samples analyzed between 1971 and 1992 were above the MDC $(0.01 \mathrm{pCi} / \mathrm{g})$ for total uranium. Only $42 \%$ of the samples analyzed by alpha spectrometry after 1992 were above the MDC (0.1 pCi/g) (Figure 3.12).

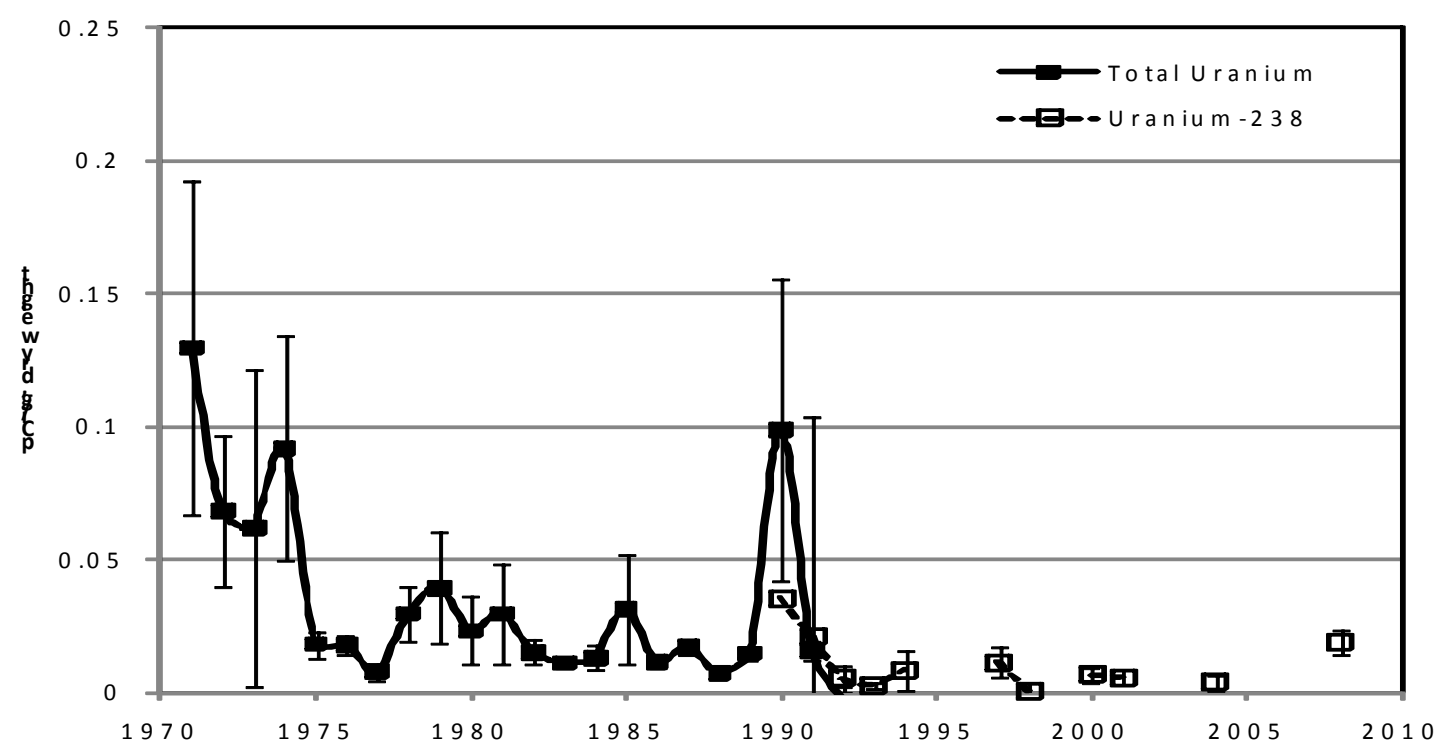

Figure 3.12. Total Uranium and Uranium- 238 Concentration (mean $\mathrm{pCi} / \mathrm{g} \pm 95 \%$ confidence interval dry weight) in Vegetation Samples Collected at Hanford and Surrounding Locations

Spatial differences in total uranium concentration in vegetation were significant, with samples from onsite areas having significantly lower total uranium concentrations than perimeter and nearby regions $(P<0.0001)$ (Table 3.37). Onsite, vegetation samples from the 300 Area had the highest total uranium concentrations similar to the soil results (Table 3.38). Total uranium concentrations in vegetation samples from the 300 Area were significantly higher than those from the other onsite areas $(P<0.02)$. The differences observed between onsite and offsite locations are likely associated with a higher concentration of available uranium in offsite soils. Most offsite soils are collected in areas not eroded by the Missoula floods, whereas most onsite areas are located in areas scoured by these floods (Duncan 2007).

Evaluation of uranium-238 concentrations in vegetation samples was hindered by the small sample size; slightly more than 100 samples were collected between 1990 and $2008(\mathrm{~N}=106)$. Prior to 1993, only 1 or 3 samples were collected each year. In addition, $56 \%$ of samples were below the MDA. The analysis indicates that offsite samples had higher concentrations than onsite, and these were associated with perimeter and nearby sites (Table 3.39). For onsite samples, those from the 300 Area had the highest mean concentration (Table 3.40).

Temporally, total uranium concentrations in vegetation showed a decrease between the 1970s and 1980s (Table 3.41). The increase in 1990 appears to be due to offsite samples (nearby and distant) with 
concentrations in excess of $0.15 \mathrm{pCi} / \mathrm{g}$ dry weight; no onsite or offsite perimeter samples were above 0.06 $\mathrm{pCi} / \mathrm{g}$. Uranium-238 concentrations were higher also in recent samples compared to those collected in the 1990s. The increase appears to be related to an increase in onsite concentrations (Figure 3.13).

Table 3.37. Total Uranium Concentrations (pCi/g dry weight) in Vegetation Samples Collected on the Hanford Site (onsite) and at Various Distances from the Site Between 1971 and 1992

\begin{tabular}{|c|c|c|c|c|}
\hline Statistics & Onsite & Perimeter & Nearby & Distant \\
\hline Median & 0.0124 & 0.0214 & 0.0170 & 0.0141 \\
\hline Mean & 0.0230 & 0.0395 & 0.0543 & 0.0400 \\
\hline Standard Deviation & 0.0511 & 0.0700 & 0.0798 & 0.0905 \\
\hline Minimum & -0.00442 & -0.00985 & 0.00077 & -0.00172 \\
\hline Maximum & 0.688 & 0.700 & 0.337 & 0.470 \\
\hline 25th Percentile ${ }^{(a)}$ & 0.0071 & 0.0120 & 0.0126 & 0.0083 \\
\hline 75th Percentile ${ }^{(a)}$ & 0.0207 & 0.0382 & 0.0477 & 0.0171 \\
\hline 95th Percentile & 0.0703 & 0.1200 & 0.2270 & 0.2510 \\
\hline $\mathrm{N}^{(\mathrm{b})}$ & 264 & 186 & 52 & 35 \\
\hline $\mathrm{N}$ above detection ${ }^{(\mathrm{c})}$ & 235 & 165 & 48 & 29 \\
\hline
\end{tabular}

(a) Fifty percent of the data occurs between these two endpoints.

(b) Number of samples.

(c) Number of samples above the analytical detection limit.

Table 3.38. Total Uranium Concentrations (pCi/g dry weight) in Vegetation Samples Collected from Different Areas on the Hanford Site (onsite) Between 1971 and 1992

\begin{tabular}{|c|c|c|c|c|c|c|}
\hline Statistics & 100 Area & 200 Area & 300 Area & 400 Area & 600 Area & Perimeter \\
\hline Median & 0.0092 & 0.0123 & 0.0197 & 0.0126 & 0.0109 & 0.0099 \\
\hline Mean & 0.0137 & 0.0267 & 0.0417 & 0.0121 & 0.0174 & 0.0225 \\
\hline Standard Deviation & 0.0138 & 0.0726 & 0.0566 & 0.0067 & 0.0174 & 0.0351 \\
\hline Minimum & -0.00442 & -0.00054 & 0.00647 & 0.00207 & 0.00290 & 0.00037 \\
\hline Maximum & 0.070 & 0.688 & 0.223 & 0.026 & 0.100 & 0.140 \\
\hline 25th Percentile ${ }^{(a)}$ & 0.0061 & 0.0071 & 0.0136 & 0.0063 & 0.0069 & 0.0061 \\
\hline 75th Percentile ${ }^{(a)}$ & 0.0163 & 0.0181 & 0.0363 & 0.0173 & 0.0210 & 0.0199 \\
\hline 95th Percentile & 0.0485 & 0.0703 & 0.2110 & 0.0235 & 0.0448 & 0.1190 \\
\hline $\mathrm{N}^{(\mathrm{b})}$ & 35 & 101 & 27 & 27 & 43 & 31 \\
\hline $\mathrm{N}$ above detection ${ }^{(\mathrm{c})}$ & 32 & 86 & 27 & 23 & 41 & 26 \\
\hline
\end{tabular}

(a) Fifty percent of the data occurs between these two endpoints.

(b) Number of samples.

(c) Number of samples above the analytical detection limit. 
Table 3.39. Uranium- 238 Concentrations (pCi/g dry weight) in Vegetation Samples Collected on the Hanford Site (onsite) and at Various Distances from the Site Between 1993 and 2008

\begin{tabular}{|c|c|c|c|c|}
\hline Statistics & Onsite & Perimeter & Nearby & Distant \\
\hline Median & 0.0027 & 0.0088 & 0.0082 & 0.0038 \\
\hline Mean & 0.0045 & 0.0112 & 0.0098 & 0.0071 \\
\hline Standard Deviation & 0.0078 & 0.0086 & 0.0091 & 0.0144 \\
\hline Minimum & -0.00653 & -0.00042 & 0.00121 & -0.00800 \\
\hline Maximum & 0.0304 & 0.0318 & 0.0354 & 0.0592 \\
\hline 25th Percentile ${ }^{(a)}$ & -0.0003 & 0.0050 & 0.0022 & 0.0005 \\
\hline 75th Percentile ${ }^{(a)}$ & 0.0063 & 0.0161 & 0.0120 & 0.0079 \\
\hline 95th Percentile & 0.0199 & 0.0299 & 0.0354 & 0.0592 \\
\hline $\mathrm{N}^{(\mathrm{b})}$ & 44 & 29 & 14 & 19 \\
\hline $\mathrm{N}$ above detection ${ }^{(\mathrm{c})}$ & 15 & 20 & 2 & 7 \\
\hline
\end{tabular}

(a) Fifty percent of the data occurs between these two endpoints.

(b) Number of samples.

(c) Number of samples above the analytical detection limit.

Table 3.40. Uranium- 238 Concentrations (pCi/g dry weight) in Vegetation Samples Collected from Different Areas on the Hanford Site Between 1993 and 2008

\begin{tabular}{|c|c|c|c|c|}
\hline Statistics & 100 Area & 200 Area & 300 Area & 600 Area \\
\hline Median & 0.0029 & 0.0058 & 0.0051 & 0.0001 \\
\hline Mean & 0.0030 & 0.0081 & 0.0096 & 0.0020 \\
\hline Standard Deviation & 0.0054 & 0.0116 & 0.0088 & 0.0071 \\
\hline Minimum & -0.00653 & -0.00364 & 0.00160 & -0.00407 \\
\hline Maximum & 0.0167 & 0.0304 & 0.0237 & 0.0188 \\
\hline 25th Percentile ${ }^{(a)}$ & -0.0005 & 0.0026 & 0.0034 & -0.0020 \\
\hline 75th Percentile ${ }^{(a)}$ & 0.0062 & 0.0079 & 0.0199 & 0.0016 \\
\hline 95th Percentile & 0.0167 & 0.0304 & 0.0237 & 0.0188 \\
\hline $\mathrm{N}^{(\mathrm{b})}$ & 19 & 6 & 7 & 12 \\
\hline $\mathrm{N}$ above detection ${ }^{(\mathrm{c})}$ & 5 & 2 & 5 & 3 \\
\hline
\end{tabular}

(a) Fifty percent of the data occurs between these two endpoints.

(b) Number of samples.

(c) Number of samples above the analytical detection limit. 
Table 3.41. Uranium Concentrations (pCi/g dry weight) in Vegetation Samples Collected On and Around the Hanford Site from 1971 Through 2001 by Decade. To compare values for total uranium to alpha energy analysis (AEA), double the AEA values to account for uranium234 under the assumption of secular equilibrium of the two uranium isotopes.

\begin{tabular}{|c|c|c|c|c|c|}
\hline \multirow[b]{2}{*}{ Statistics } & \multicolumn{3}{|c|}{ Total Uranium } & \multicolumn{2}{|c|}{ U-238 (AEA) } \\
\hline & 1970 & 1980 & 1990 & 1990 & 2000 \\
\hline Median & 0.0256 & 0.0120 & 0.0215 & 0.0034 & 0.0068 \\
\hline Mean & 0.0533 & 0.0166 & 0.0518 & 0.0064 & 0.0084 \\
\hline Standard Deviation & 0.0885 & 0.0250 & 0.0934 & 0.0114 & 0.0085 \\
\hline Minimum & 0.00000 & -0.00054 & -0.00985 & -0.00800 & -0.00407 \\
\hline Maximum & 0.7000 & 0.3210 & 0.4700 & 0.0592 & 0.0318 \\
\hline 25th Percentile ${ }^{(a)}$ & 0.0130 & 0.0073 & 0.0107 & 0.0010 & 0.0020 \\
\hline 75th Percentile ${ }^{(a)}$ & 0.0500 & 0.0171 & 0.0382 & 0.0076 & 0.0117 \\
\hline 95th Percentile & 0.2220 & 0.0384 & 0.2510 & 0.0294 & 0.0299 \\
\hline $\mathrm{N}^{(\mathrm{b})}$ & 196 & 298 & 43 & 48 & 58 \\
\hline $\mathrm{N}$ above detection ${ }^{(\mathrm{c})}$ & 184 & 256 & 37 & 35 & 19 \\
\hline
\end{tabular}
(a) Fifty percent of the data occurs between these two endpoints.
(b) Number of samples.
(c) Number of samples above the analytical detection limit.
AEA = Alpha energy analysis.

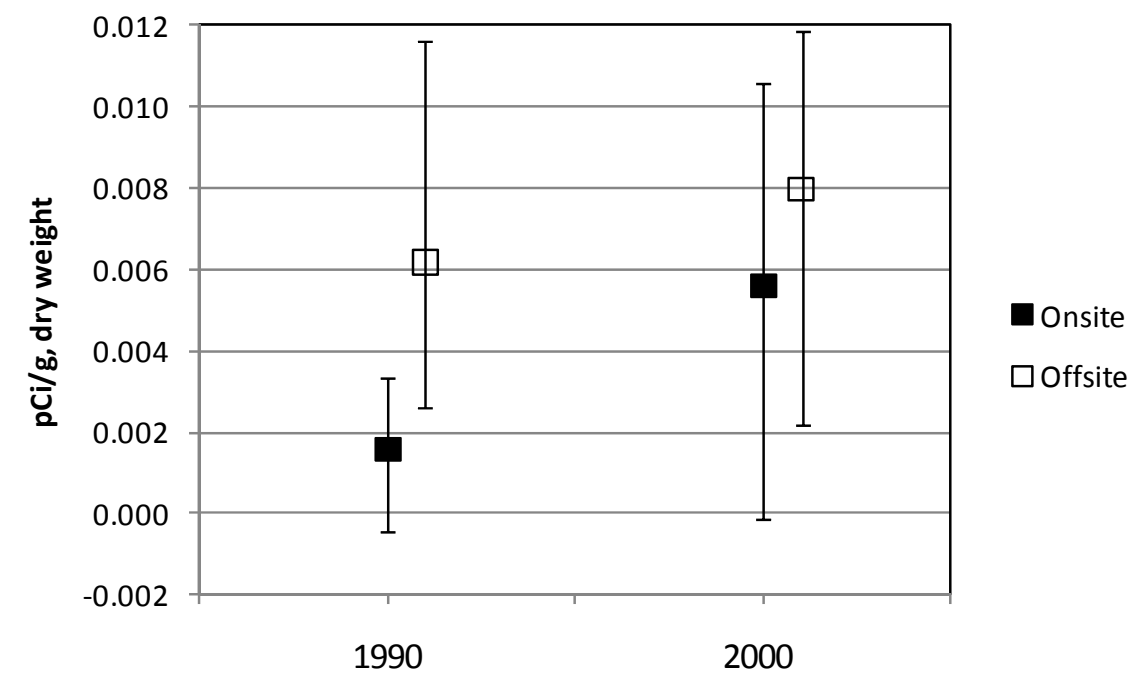

Figure 3.13. Median Uranium- 238 Concentrations (pCi/g dry weight) in Vegetation Samples Collected from Onsite (i.e., 100, 200, 300, 400, and 600 Areas) and Offsite (i.e., perimeter, nearby, and distant) Areas by Decade. Error bars encompass $50 \%$ of the data around the median. 


\subsection{Site Environmental Benchmarks and Guidance Levels}

To assess the potential impact to people and the environment from the accumulation of radionuclides in soil and plants requires an evaluation of potential dose consequences to organisms. For this report, this evaluation will focus on both concentration-dependent and dose-dependent benchmarks. Uranium was evaluated also as a metal, and results are expressed gravimetrically as opposed to an activity concentration.

The development of site surveillance sampling screening values provides for a direct and conservative approach to assessing the potential impact from radionuclide concentrations in surveillance soil samples. Through multipathway dose modeling, these benchmarks are set at soil concentrations that correspond to a 10-mrem 50-year equivalent dose for strontium-90 and cesium-137 and 1-mrem dose for plutonium and uranium isotopes. For these comparisons, data were grouped as either onsite or offsite, and the 95th percentile value was determined. The 95th percentile value was compared to the soil screening values used for surveillance monitoring (Table 3.42). A comparison of current DOE reporting levels to these 95th percentile radionuclide concentrations over the past four decades indicates that soil concentrations in the 1980s exceeded current screening reporting levels for cesium-137; in the 1970s through 1990s, soil concentrations exceeded current screening reporting levels for strontium-90 onsite. Offsite, strontium-90 concentrations in soils exceeded the screening levels in the 1970s and 1980s. These exceedances for strontium-90 in offsite soil samples reflect fallout from atmospheric weapons testing rather than releases for the Hanford Site and point to the high level of conservatism embodied in the soil screening benchmarks. The onsite and offsite 95 th percentile concentrations for the remaining radionuclides covered in this report did not exceed their respective soil surveillance benchmarks over the four study decades.

DOE has developed a method for assessing dose rates to biota (DOE 2002). The process is a graded approach based on the protection of populations of wildlife rather than individuals. At the screening level, DOE established biota concentration guides that provide a conservative benchmark for the protection for terrestrial animals based on a $0.1-\mathrm{rad} / \mathrm{d}$ dose rate. The biota dose guides for soil greatly exceed the screening levels in the Environmental Monitoring Plan (DOE 2008) for the radionuclides evaluated in this report (Table 3.42).

A direct dose comparison can be made of radiological impacts to plants by comparing the resulting internal dose as determined from dose conversion factors and the 95 th percentile radionuclide concentrations in plants (Table 3.43). In this case, the biota dose guideline of $1 \mathrm{rad} / \mathrm{d}$ for terrestrial vegetation was used as a benchmark (DOE 2002). Data were grouped by decade as either onsite or offsite, and the 95th percentile of the concentrations was determined. In no case, either onsite or offsite, did any of these conservative dose calculations come within a factor of 100,000 of the 1-rad/day benchmark for vegetation, and most were several orders of magnitude lower. As would be expected, onsite dose calculations slightly exceeded offsite dose calculations, and most of the maximum dose estimates were associated with samples collected in the 1970s.

The last evaluation was a comparison of uranium concentrations to ecotoxicological benchmarks (Sheppard et al. 2006). This comparison requires a conversion of uranium activity concentrations to a gravimetric concentration. The 95th percentile values from Table 3.44 were used for the comparison. Sheppard et al. (2006) derived benchmarks for uranium for terrestrial plants and animals. The respective soil benchmarks are $250 \mathrm{mg} \mathrm{U} / \mathrm{kg}$ dry weight soil for plants and $100 \mathrm{mg} \mathrm{U} / \mathrm{kg}$ dry weight soil for other 
soil biota. All 95th percentile concentrations ranged between factors of 20 or more below the soil biota benchmark and factors of 60 or more when compared to the plant benchmark. Sample preparation methods that recovered the leachable fraction of uranium had less risk than those methods that provided a total concentration of uranium.

Table 3.42. Site Surveillance Screening Criteria for Soils (pCi/g dry weight) and the Determination of the Soil Exposure Pathway for Protection of the Offsite Human Population and Biota Concentration Guides

\begin{tabular}{|c|c|c|c|c|c|c|c|}
\hline \multirow[b]{2}{*}{ Radionuclide } & \multirow[b]{2}{*}{ Location } & \multicolumn{4}{|c|}{$\begin{array}{l}\text { 95th Percentile Concentrations by Location and } \\
\text { Decade (pCi/g dry wt.) }\end{array}$} & \multirow{2}{*}{$\begin{array}{c}\text { Hanford Site } \\
\text { Screening Level } \\
\text { (EMP) } \\
\text { pCi/g dry wt. }\end{array}$} & \multirow{2}{*}{$\begin{array}{c}\text { Biota Concentration } \\
\text { Guideline } \\
\text { (RESRAD- } \\
\text { BIOTA }{ }^{(b)} \\
\text { pCi/g dry wt. }\end{array}$} \\
\hline & & 1970 & 1980 & 1990 & 2000 & & \\
\hline \multirow[t]{2}{*}{ Cobalt-60 } & Onsite & 0.15 & 0.05 & 0.03 & 0.02 & \multirow[t]{2}{*}{0.30} & \multirow[t]{2}{*}{700} \\
\hline & Offsite & 0.10 & 0.03 & 0.03 & 0.02 & & \\
\hline \multirow[t]{2}{*}{ Cesium-137 } & Onsite & 3.01 & $18^{(\mathrm{c})}$ & 2.29 & 1.13 & \multirow[t]{2}{*}{5.8} & \multirow[t]{2}{*}{20} \\
\hline & Offsite & 1.52 & 1.4 & 1.19 & 0.47 & & \\
\hline \multirow[t]{2}{*}{ Strontium-90 } & Onsite & 0.76 & 1.13 & 0.58 & 0.23 & \multirow[t]{2}{*}{0.30} & \multirow[t]{2}{*}{20} \\
\hline & Offsite & 0.38 & 0.65 & 0.20 & 0.14 & & \\
\hline \multirow[t]{2}{*}{ Plutonium -238 } & Onsite & 0.0080 & 0.0057 & 0.0033 & 0.0028 & \multirow[t]{2}{*}{3.7} & \multirow[t]{2}{*}{70} \\
\hline & Offsite & 0.0063 & 0.0020 & 0.0024 & 0.0029 & & \\
\hline \multirow{2}{*}{$\begin{array}{l}\text { Plutonium- } \\
239 / 240\end{array}$} & Onsite & 0.0757 & 0.3370 & 0.2860 & 0.0928 & \multirow[t]{2}{*}{3.7} & \multirow[t]{2}{*}{6000} \\
\hline & Offsite & 0.0252 & 0.0277 & 0.0214 & 0.0145 & & \\
\hline \multirow{2}{*}{$\begin{array}{l}\text { Uranium (Total - } \\
\text { Fluorometry) }\end{array}$} & Onsite & 0.70 & 0.80 & NA & NA & \multirow[t]{2}{*}{3.1} & \multirow[t]{2}{*}{2000} \\
\hline & Offsite & 0.70 & 0.92 & NA & NA & & \\
\hline \multirow{2}{*}{$\begin{array}{l}\text { Uranium-238 } \\
\text { (Gamma-LEPS) }\end{array}$} & Onsite & NA & 1.18 & 1.24 & NA & \multirow[t]{2}{*}{3.1} & \multirow[t]{2}{*}{2000} \\
\hline & Offsite & NA & 1.42 & 1.13 & NA & & \\
\hline \multirow{2}{*}{$\begin{array}{l}\text { Uranium-238 } \\
\text { (Alpha-total) }\end{array}$} & Onsite & NA & NA & 1.02 & NA & \multirow[t]{2}{*}{3.1} & \multirow[t]{2}{*}{2000} \\
\hline & Offsite & NA & NA & 0.86 & NA & & \\
\hline \multirow{2}{*}{$\begin{array}{l}\text { Uranium-238 } \\
\text { (Alpha-acid) }\end{array}$} & Onsite & NA & NA & 0.36 & 0.61 & \multirow[t]{2}{*}{3.1} & \multirow[t]{2}{*}{2000} \\
\hline & Offsite & NA & NA & 0.44 & 0.66 & & \\
\hline
\end{tabular}

(a) $\operatorname{DOE}(2008)$.

(b) $\operatorname{DOE}(2002,2004)$.

(c) This value influence by a maximum value of 35.2 collected in 1979 in the 200 Area at the East North Central location.

EMP = Environmental Monitoring Plan (DOE 2008).

LEPS = Low-energy photon spectrometry.

The analyses of radionuclide concentrations in soil and vegetation summarized in this report identify a persistent footprint of low-level radiological contamination on the Hanford Site. This footprint is related to past production and waste management operations and fallout from past atmospheric weapons testing programs. Nearly all samples collected recently on the site and most of those collected in the past had concentrations well below dose-based guidelines for the protection of human health and the environment. At no time has a surveillance soil sample collected at onsite or offsite sampling locations exceeded a level that would result in exceedance of the 100-mrem annual dose limit administered by the DOE. The actual contribution from soils is small compared to other routes of exposure. Surveillance soil 
samples should not be confused with facility or waste site soil samples that may have elevated radionuclide concentrations resulting from past operations and waste management practices. The latter were collected within facility boundaries.

Table 3.43. Comparison of Internal Dose Rates (rad/d) to Plants Based on the 95th Percentile Value by Decade and Location. The DOE guidance value is $1 \mathrm{rad} / \mathrm{d}$ for terrestrial plants.

\begin{tabular}{lccccccc}
\hline & & \multicolumn{3}{c}{$\begin{array}{c}\text { 95th Percentile Concentration by Decade } \\
\text { (pCi/g dry wt.) }\end{array}$} & \multicolumn{2}{c}{$\begin{array}{c}\text { Maximum Internal } \\
\text { Dose Rate and } \\
\text { Decade }\end{array}$} \\
\cline { 3 - 8 } \multicolumn{1}{c}{ Radionuclide } & Location & 1970 & 1980 & 1990 & 2000 & Rad/d & Decade \\
\hline Cobalt-60 & Onsite & 0.90 & 0.12 & 0.04 & 0.01 & $1.4 \mathrm{E}-11$ & 1970 \\
& Offsite & 0.11 & 0.04 & 0.02 & 0.02 & $1.5 \mathrm{E}-12$ & 1970 \\
Cesium-137 & Onsite & 16.3 & 0.25 & 0.11 & 0.02 & $4.1 \mathrm{E}-10$ & 1970 \\
& Offsite & 1.19 & 0.98 & 0.03 & 0.02 & $4.2 \mathrm{E}-11$ & 1970 \\
Strontium-90 & Onsite & 0.42 & 0.91 & 0.54 & 0.05 & $1.0 \mathrm{E}-10$ & 1980 \\
& Offsite & 0.26 & 0.18 & 0.16 & 0.06 & $3.0 \mathrm{E}-11$ & 1970 \\
Plutonium-238 & Onsite & 0.0113 & 0.0006 & 0.0007 & 0.0002 & $3.8 \mathrm{E}-12$ & 1970 \\
& Offsite & 0.0142 & 0.0013 & 0.0003 & 0.0002 & $8.5 \mathrm{E}-12$ & 1970 \\
Plutonium- & Onsite & 0.0222 & 0.0044 & 0.0066 & 0.0069 & $5.9 \mathrm{E}-12$ & 1970 \\
$239 / 240$ & Offsite & 0.0183 & 0.0250 & 0.0007 & 0.0013 & $1.2 \mathrm{E}-11$ & 1970 \\
Uranium (Total) & Onsite & 0.163 & 0.029 & 0.036 & NA & $8.0 \mathrm{E}-06$ & 1970 \\
& Offsite & 0.229 & 0.049 & 0.312 & NA & $1.5 \mathrm{E}-05$ & 1990 \\
Uranium-238 & Onsite & NA & NA & 0.0065 & 0.0237 & $3.2 \mathrm{E}-07$ & 1980 \\
(Alpha-total) & Offsite & NA & NA & 0.0354 & 0.0299 & $2.9 \mathrm{E}-06$ & 1980 \\
\hline NA = Not available. & & & & & & & \\
\hline
\end{tabular}

Table 3.44. Conversion of 95th Percentile Uranium Soil Concentrations (mg U/kg soil dry weight) for Comparison to Ecotoxicity Benchmarks ${ }^{\text {(a) }}$

\begin{tabular}{cccccc}
\hline \multicolumn{1}{c}{ Method $^{(\mathrm{b})}$} & Grouping & 1970 & 1980 & 1990 & 2000 \\
\hline Total Uranium (Fluorometry) & Onsite & 1.06 & 1.32 & NA & NA \\
& Offsite & 1.06 & 1.39 & NA & NA \\
Uranium-238 (Gamma-LEPS) & Onsite & NA & 3.58 & 3.42 & NA \\
& Offsite & NA & 4.30 & 3.74 & NA \\
\multirow{2}{*}{ Uranium-238 (Alpha-total) } & Onsite & NA & NA & 3.09 & NA \\
& Offsite & NA & NA & 3.42 & NA \\
& Onsite & NA & NA & 1.08 & 0.72 \\
Uranium-238 (Alpha-acid) & Offsite & NA & NA & 1.34 & 1.13 \\
\hline
\end{tabular}

(a) $250 \mathrm{mg} \mathrm{U} / \mathrm{kg}$ soil for plants and $100 \mathrm{mg} \mathrm{U} / \mathrm{kg}$ soil for other soil biota (dry weight basis).

(b) Total uranium concentration from Table 3.42 divided by 2 and multiplied by 3.0303 to convert $\mathrm{pCi} / \mathrm{g}$ to $\mu \mathrm{g} / \mathrm{g}(=\mathrm{mg} / \mathrm{kg})$; all other uranium-238 concentrations converted directly. Contributions of uranium-234 and uranium-235 to the mass were considered negligible for this comparison.

LEPS $=$ Low-energy photon spectrometry. 


\subsection{Conclusions}

We analyzed radionuclide concentrations in surface soil and perennial vegetation samples collected as part of Hanford Site surveillance activities conducted from 1971 to 2008 and land release projects from 2002 to 2006. This report focuses specifically on radionuclides that are still being monitored routinely and reported in site environmental reports. Spatial and temporal trends were evaluated for cobalt-60, cesium-137, strontium-90, plutonium-238, plutonium-239/240, and uranium, reported either as total uranium or uranium-238.

From the analysis, we concluded the following:

- The statistical distribution of soil and vegetation data generally followed a log-normal distribution, which was consistent with previous assessments of radionuclide concentrations.

- Temporal decreases in soil concentrations of cesium-137 and strontium-90 are consistent with expected changes due primarily to radiological decay. As monitored concentrations approach the limits of detection over time, the variability associated with the samples as a group has decreased.

- Temporal trends for plutonium and uranium in soil and vegetation samples suggest concentrations decreased in the 1990s compared to the 1970s or 1980s. Given the long radiological half-lives of plutonium and uranium isotopes, this apparent decrease cannot be explained by radiological or the more obvious environmental processes but may be related to more accurate and precise analytical methods used in recent years.

- Spatial distribution of the analyzed radionuclides in soil and vegetation is consistent with previous site activities and low-level releases associated with specific operations in the 100, 200, and 300 Areas. Cobalt-60 concentrations in soil and vegetation were highest in the 100 Areas where most sampling sites were located near the 100-N Area. Cesium-137, strontium-90, plutonium-238, and plutonium239/240 concentrations were the highest in the 200 Area where reactor fuel was processed and waste was managed and stored. The 300 Area had the highest uranium concentrations in soil and vegetation, reflecting its role in fuel fabrication.

- Surveillance soil concentrations fall well below benchmark concentrations established for protecting human health and the environment. Historically, some radionuclide concentrations collected onsite exceeded site-specific screening levels established in 1990.

Overall, the concentrations of radionuclides in soil and vegetation currently found at Hanford Site surveillance locations and land release areas are at low environmental levels that may be expected to exist naturally or are associated with atmospheric deposition. For assessment purposes, the soil data has much more utility for assessing potential impact of long-term radiological releases at the Hanford Site because soil generally retains these contaminants in the upper horizons. Of the six radionuclides evaluated in this assessment, strontium-90 has the greatest potential to migrate into deeper soil horizons (Price 1991). The vegetation data, on the other hand, represent the current season's growth. Generally, vegetation had much lower concentrations than found in soil and, as such, is more useful for detecting releases of radionuclides that settle onto the plant material. Historically, vegetation provided a valuable medium for tracking the deposition of iodine-131 before fuel process technology progressed to a point where atmospheric releases were contained. 
Soil and vegetation surveillance has been a valuable component of surveillance objectives and DOE's obligations to monitor and protect the environment. Soil data from activities supporting cleanup and land release (Dirkes et al. 2002; Fritz et al. 2003, 2007a, 2007b) were used in this assessment of surveillance data to better characterize radionuclide distributions in recent years.

Offsite data reported here have been incorporated in annual Hanford Site environmental reports (e.g., Poston et al. 2010) to corroborate atmospheric modeling of Hanford Site effluents to determine maximum offsite dose estimates to the public. In recent years, the annual dose contribution from Hanford to the MEI has been less than 0.12 mrem and includes all sources of potential exposure (Poston et al. 2010). For comparison, the national average annual background dose rate associated with external radiation (including radon) is $200 \mathrm{mrem}$. 


\subsection{References}

Albin L and R Jaquish. 2002. Analysis of Environmental Radiological Data Relating to the 2000 Wildfire at Hanford. WDOH/320-025, Washington Department of Health, Olympia.

Antonio EJ, TM Poston, and WH Rickard, Jr. 1993. Radiological Survey of Shoreline Vegetation from the Hanford Reach of the Columbia River, 1990-1992. PNL-8797, Pacific Northwest Laboratory, Richland, Washington.

Bisping LE. 2006. Hanford Site Environmental Surveillance Master Sampling Schedule for Calendar Year 2006. PNNL-15618, Pacific Northwest National Laboratory, Richland, Washington.

Cadwell LL and TM Poston. 2001. "The 2000 '24 Command' Hanford Site Wildfire.” In Hanford Site Environmental Report for Calendar Year 2000, eds. TM Poston, RW Hanf, RL Dirkes, and LF Morasch, pp. 5.1-5.21. PNNL-13487, Pacific Northwest National Laboratory, Richland, Washington.

Cantrell KJ, RJ Serne, and GV Last. 2003. Hanford Contaminant Distribution Coefficient Database and Users Guide. PNNL-13895, Pacific Northwest National Laboratory, Richland, Washington.

Clean Air Act. 1986. Public Law 88-206, as amended, 42 USC 7401 et seq.

Clean Water Act of 1977. 1977. Public Law 95-217, as amended, 33 USC 1251 et seq.

Coughtrey PJ and MC Thorne. 1983. Radionuclide Distribution and Transport in Terrestrial and Aquatic Ecosystems A Critical Review of Data, Volume Two. Balkema/Rotterdam.

Dirkes RL and RW Hanf. 1996. Hanford Site Environmental Report for Calendar Year 1995. PNNL-11139, Pacific Northwest National Laboratory, Richland, Washington.

Dirkes RL (ed.), BA Napier, EJ Antonio, TM Poston, and BG Fritz. 2002. Evaluation of Radionuclide Concentrations in Support of Radiological Release of the WNP-1 and WNP-4 Sites at Hanford. PNNL-14046, Pacific Northwest National Laboratory, Richland, Washington.

DOE. 1991. Environmental Regulatory Guide for Radiological Effluent Monitoring and Environmental Surveillance. U.S. Department of Energy, Washington, D.C.

DOE. 1996. Hanford Site Background: Part 2, Soil Background for Radionuclides. DOE/RL-96-12, U.S. Department of Energy, Richland Operations Office, Richland, Washington.

DOE. 2002. A Graded Approach for Evaluating Radiation Doses to Aquatic and Terrestrial Biota. DOE-STD-1153-2002, U.S. Department of Energy, Washington, D.C. Available at http://www.hss.doe.gov/nuclearsafety/ns/techstds/standard/std1153/1153.htm (July 2011).

DOE. 2004. RESRAD-BIOTA: A Tool for Implementing a Graded Approach to Biota Dose Evaluation, User's Guide, Version 1. ISCORS Technical Report 2004-02, DOE/EH-0676, Interagency Steering Committee on Radiation Standards, U.S. Department of Energy, Washington, D.C. 
DOE. 2008. Environmental Monitoring Plan. DOE/RL-91-50, Rev. 4, U.S. Department of Energy, Richland Operations Office, Richland, Washington.

DOE Order 231.1A Chg 1, Environment, Safety and Health Reporting. U.S. Department of Energy, Washington, D.C.

DOE Order 450.1-6, Ground Water Surveillance Monitoring Implementation Guide for Use with DOE O 450.1, Environmental Protection Program. U.S. Department of Energy, Washington, D.C.

DOE Order 5400.1 Chg 1, General Environmental Protection Program. U.S. Department of Energy, Washington, D.C.

Duncan JP. 2007. Hanford Site National Environmental Policy Act (NEPA) Characterization. PNNL6415, Rev 18, Pacific Northwest National Laboratory, Richland, Washington.

Eberhardt LE and RO Gilbert. 1980. "Statistics and Sampling in Transuranic Studies." In Transuranic Elements in the Environment, ed. WC Hanson, pp. 173-186. DOE/TIC-22800, National Technical Information Service, Springfield, Virginia.

Fix JL. 1975. Environmental Surveillance at Hanford for CY-1974. BNWL-1910, Battelle, Pacific Northwest Laboratories, Richland, Washington.

Fritz BG, RL Dirkes, and BA Napier. 2007a. Soil Sampling to Demonstrate Compliance with Department of Energy Radiological Clearance Requirements for the McGee Ranch-Riverlands and North Slope Units of the Hanford Reach National Monument. PNNL-16883, Pacific Northwest National Laboratory, Richland, Washington.

Fritz BG, RL Dirkes, and BA Napier. 2007b. Soil Sampling to Demonstrate Compliance with Department of Energy Radiological Clearance Requirements for the ALE Unit of the Hanford Reach National Monument. PNNL-14937, Rev. 1, Pacific Northwest National Laboratory, Richland, Washington.

Fritz BG, RL Dirkes, TM Poston, and RW Hanf. 2003. Historical Site Assessment: Select Hanford Reach National Monument Lands - Fitzner/Eberhardt Arid Lands Ecology Reserve (ALE), McGee Ranch/Riverlands, and North Slope Units. PNNL-13989, Pacific Northwest National Laboratory, Richland, Washington.

Gilbert RO. 1987. Statistical Methods for Environmental Pollution Monitoring. Van Nostrand Reinhold Company, New York.

Gotelli NJ and AM Ellison. 2004. A Primer of Ecological Statistics. Sinauer Associates, Inc., Sunderland, Massachusetts.

Hanf RW, TM Poston, and LE Bisping. 2007. Surface Environmental Surveillance Procedures Manual, PNL-MA-580, Rev. 5. PNL-16744, Pacific Northwest National Laboratory, Richland, Washington. 
Helsel DR, DK Mueller, and JR Slack. 2006. Computer Program for the Kendall Family of Trend Tests. Scientific Investigations Report 2005-5275, U.S. Geological Survey. Available at http://pubs.usgs.gov/sir/2005/5275/ (July 2011).

Hossner LR, RH Loeppert, RH Newton, and PJ Szaniszlo. 1998. Literature Review: Phytoaccumulation of Chromium, Uranium, and Plutonium in Plant Systems. ANRCP-1998-3, Amarillo National Resources Center for Plutonium, Amarillo, Texas.

Hunt WF, Jr., G Akland, W Cox, T Curran, N Frank, S Goranson, P Ross, H Sauls, and J Suggs. 1981. U.S. Environmental Protection Agency Intra-Agency Task Force Report on Air Quality Indicators. EPA-450/4-81-015, U.S. Environmental Protection Agency, National Technical Information Service, Springfield, Virginia.

Jones JB Jr. and F Haghiri. 1962. "Reducing the Uptake of $\mathrm{Sr}^{90}$ by Plants on Contaminated Ohio Soils." The Ohio Journal of Science 62(2):97-100.

Junkins RL, EC Watson, IC Nelson, and RC Henle. 1960. Evaluation of Radiological Conditions in the Vicinity of Hanford for 1959. HW-64371, Hanford Atomics Products Operation, Richland, Washington.

Miller ML, JJ Fix, and PE Bramson. 1977. Radiochemical Analyses of Soil and Vegetation Samples Taken from the Hanford Environs, 1971-1976. BNWL-2249, Battelle, Pacific Northwest Laboratories, Richland, Washington.

Nees WL and JP Corley. 1974. Environmental Surveillance at Hanford for CY-1973. BNWL-1811, Battelle, Pacific Northwest Laboratories, Richland, Washington.

Noonan CF and DC Stapp. 2003. "Research and Development." Section 7 in Hanford Site Historical District, History of the Plutonium Production Facilities 1943-1990. Battelle Press, Columbus, Ohio.

Perkins RW and CW Thomas. 1980. "Worldwide Fallout." In Transuranic Elements in the Environment, ed. WC Hanson, pp. 53-82. DOE/TIC-22800, National Technical Information Service, Springfield, Virginia.

Perkins CJ, MC Dorsey, SM McKinney, and RM Mitchell. 2005. Hanford Site Near-Facility Environmental Monitoring Data Report for Calendar Year 2004. PNNL-15222-APP. 2, Duratek Federal Services, Richland, Washington.

Peterson J M, MM MacDonell, LA Haroun, FA Monette, RD Hildebrand, and A Taboas. 2007. Radiological and Chemical Fact Sheets to Support Health Risk Analyses for Contaminated Areas. Argonne National Laboratory, Argonne, Illinois. Available at http://www.ead.anl.gov/pub/ dsp detail.cfm?PubID=1472 (September 2009).

Peterson RE and TM Poston. 2000. Strontium-90 at the Hanford Site and its Ecological Implications. PNNL-13127, Pacific Northwest National Laboratory, Richland, Washington.

Poston TM, RE Peterson, and AT Cooper. 2007. "Past Radioactive Particle Contamination in the Columbia River at the Hanford Site, USA." Journal of Radiological Protection 27:A45-A50. 
Poston TM, JP Duncan, and RL Dirkes. 2010. Hanford Site Environmental Report for Calendar Year 2009. PNNL-18427, Pacific Northwest National Laboratory, Richland, Washington.

Poston TM, EJ Antonio, and AT Cooper. 1995. Radionuclide Concentrations in Terrestrial Vegetation and Soil on and Around the Hanford Site, 1983 Through 1993. PNNL-10728, Pacific Northwest National Laboratory, Richland, Washington.

Price KR. 1987. "Soil and Vegetation Monitoring." In Environmental Monitoring at Hanford for 1986, pp. 3.46-2.50. PNL-6120, Pacific Northwest Laboratory, Richland, Washington.

Price KR. 1988. Review of Historical Data on the Radionuclide Content of Soil Samples Collected from the Hanford Site and Vicinity. PNL-6734, Pacific Northwest Laboratory, Richland, Washington.

Price KR. 1991. "The Depth Distribution of ${ }^{90} \mathrm{Sr},{ }^{137} \mathrm{Cs}$, and ${ }^{239,240} \mathrm{Pu}$ in Soil Profile Samples." Radiochimica Acta 54:145-147.

Price KR and WH Rickard. 1997. Historical Review of Long-Term Soil Sampling for Environmental Surveillance at the Hanford Site and Vicinity. PNNL-11673, Pacific Northwest National Laboratory, Richland, Washington.

Sheppard SC, MI Sheppard, JC Tait, and BL Sanipelli. 2006. "Revision and Meta-Analysis of Selected Biosphere Parameter Values for Chlorine, Iodine, Neptunium, Radium, Radon, and Uranium." Journal of Environmental Radioactivity 89:115-137.

Sula M. 1980. Radiological Survey of Exposed Shorelines and Islands of the Columbia River Between Vernita and the Snake River Confluence. PNL-3127, Pacific Northwest Laboratory, Richland, Washington.

Van Verst SP and CL Albin. 2002. Hanford Environmental Oversight Program 2002 Data Summary Report. DOH 320-036, Washington State Department of Health, Olympia.

WAC 173-201A. 2006. "Water Quality Standards for Surface Waters of the State of Washington." Washington Administrative Code, Olympia.

WAC 246-247. 2005. "Radiation Protection - Air Emissions." Washington Administrative Code, Olympia.

Wildung RE and TR Garland. 1974. "Influence of Soil Plutonium Concentration on Plutonium Uptake and Distribution in Shoots and Roots of Barley." Journal of Agricultural and Food Chemistry 22:836-838.

Woodruff RK. 1987. “Air Monitoring.” In Environmental Monitoring at Hanford for 1986. PNL-6120, Pacific Northwest Laboratory, Richland, Washington. 
Appendix A

\section{Sample Site Locations}





\section{Appendix A}

\section{Sample Site Locations}

Names for sampling site locations were established by sampling staff based on geographic location with established buildings and features in the vicinity of the site. The advent of computerized databases also placed limits on the number of characters that could be used to name a site. Some sites have had two or three names established before the Hanford Environmental Information System (HEIS) was implemented (Table A.1). As a result, some sites have truncated or abbreviated names in HEIS. This is important if the reader goes back to review previous technical reports with the expectation of identifying sites by their more recent nomenclature.

Table A.1. Changes in Soil and Vegetation Sampling Location Names That Have Occurred Since 1971

\begin{tabular}{|c|c|c|c|}
\hline HEIS Site Name & $\begin{array}{l}\text { HEIS Site } \\
\text { Identification } \\
\text { Number }\end{array}$ & $\begin{array}{l}1983 \text { Location Manual Name } \\
\text { (PNL-MA-514) }\end{array}$ & $\begin{array}{l}\text { Master Sampling Schedule Site } \\
\text { Name }^{(\text {a) }}\end{array}$ \\
\hline $200 \mathrm{ESE}$ & 218 & $200 \mathrm{ESE}$ & $\begin{array}{l}200 \text { ESE AIR SAMPLING } \\
\text { STATION }\end{array}$ \\
\hline $400 \mathrm{E}$ & 603 & NE FFTF & 1/2 MILE NE OF FFTF SITE \\
\hline ALE FIELD LAB ${ }^{(b)}$ & 528 & ALE & EAST OF ALE FIELD LAB \\
\hline E OF 100 N AREA & 205 & 1 MILE E OF N AREA & 1 MILE E OF N AREA \\
\hline E OF 200 E & 508 & 1.25 MILES E OF PUREX & 1.25 MILES E OF PUREX \\
\hline N END VERNITA BRIDGE & 395 & VERNITA BRIDGE N END & VERNITA BRIDGE N END \\
\hline NE OF 100 N AREA & 535 & 1 MILE NE OF N AREA & 1 MILE NE OF N AREA \\
\hline NORTH 300 AREA & 76 & N OF 300 AREA & N OF 300 AREA \\
\hline S OF $200 \mathrm{E}$ & 119 & 2 MILES S OF PUREX & 2 MILES S OF PUREX \\
\hline S OF $200 \mathrm{~W}$ & 417 & 2 MILES S OF $200 \mathrm{~W}$ & 2 MILES S OF $200 \mathrm{~W}$ \\
\hline SE SIDE OF FFTF & 140 & SE FFTF & SE SIDE OF FFTF SITE \\
\hline SOUTH 300 AREA & 77 & S OF 300 AREA & S OF 300 AREA \\
\hline SW OF B/C CRIBS & 419 & 3 MILES SSW OF PUREX & SW OF BC CRIBS \\
\hline WAHLUKE SLOPE & 596 & WAHLUKE SLOPE \#2 & $\begin{array}{l}\text { WAHLUKE \#2 AIR } \\
\text { SAMPLING STATION }\end{array}$ \\
\hline
\end{tabular}

(a) Preceding HEIS.

(b) Also identified as EOC (Emergency Operations Center) in Hanford's early years.

Map locations of soil and vegetation sampling sites are provided in Figures A.1 through A.9. For locations that were sampled in recent years, Global Positioning System (GPS) technology was used to establish map coordinates. For sites that were not sampled before the implementation of GPS technology, their map locations and GPS coordinates were established by reviewing locations, manuals, and annual site environmental reports, then pinpointing the sampling location with Google Earth and pulling the GPS coordinates from that map. In some cases, GPS coordinates derived from this process are very coarse, and the place of that particular sampling location is at best an educated guess. 


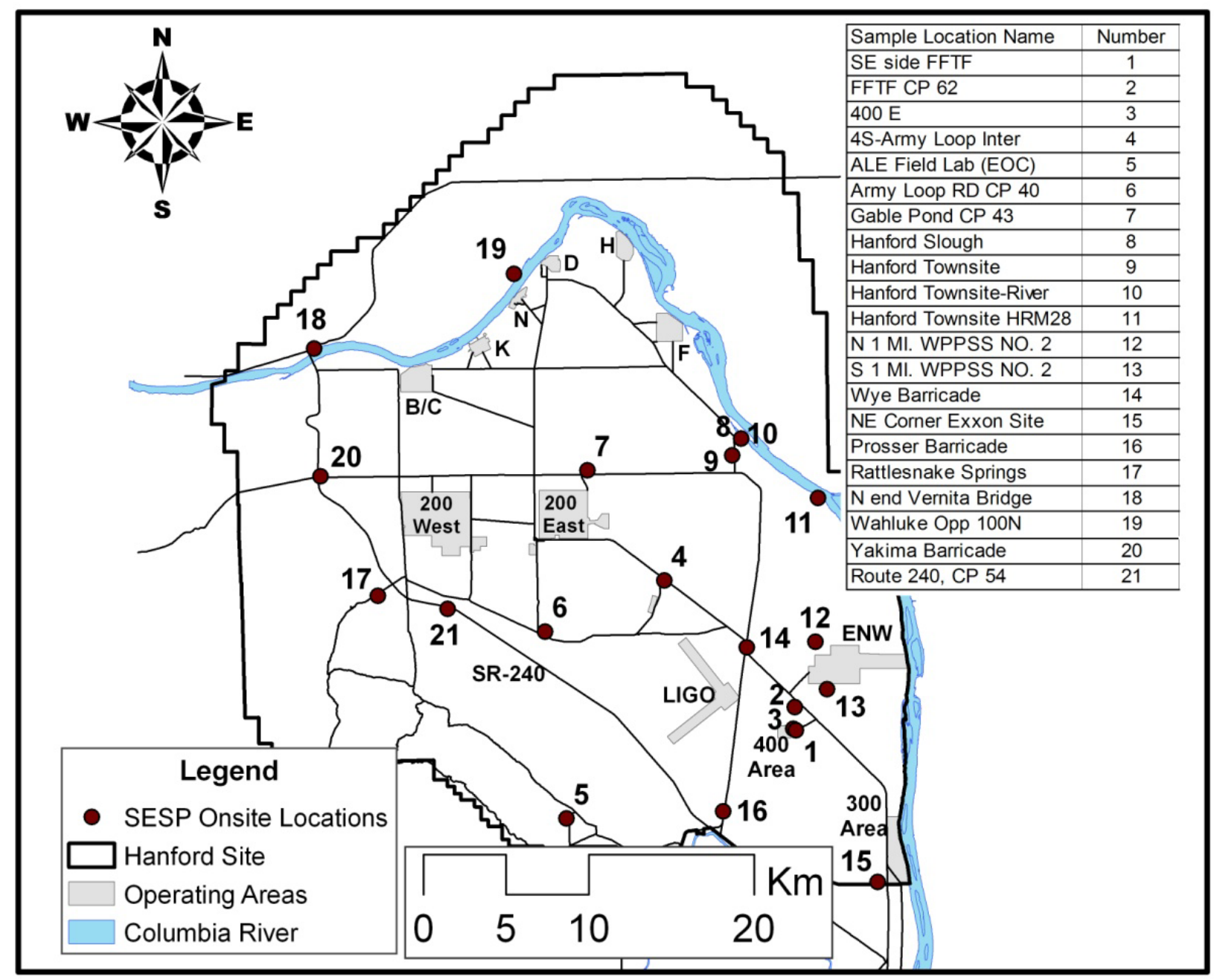

Figure A.1. Soil and Vegetation Sampling Sites Associated with Onsite Locations, Surveillance Monitoring from 1971 Through 2008 


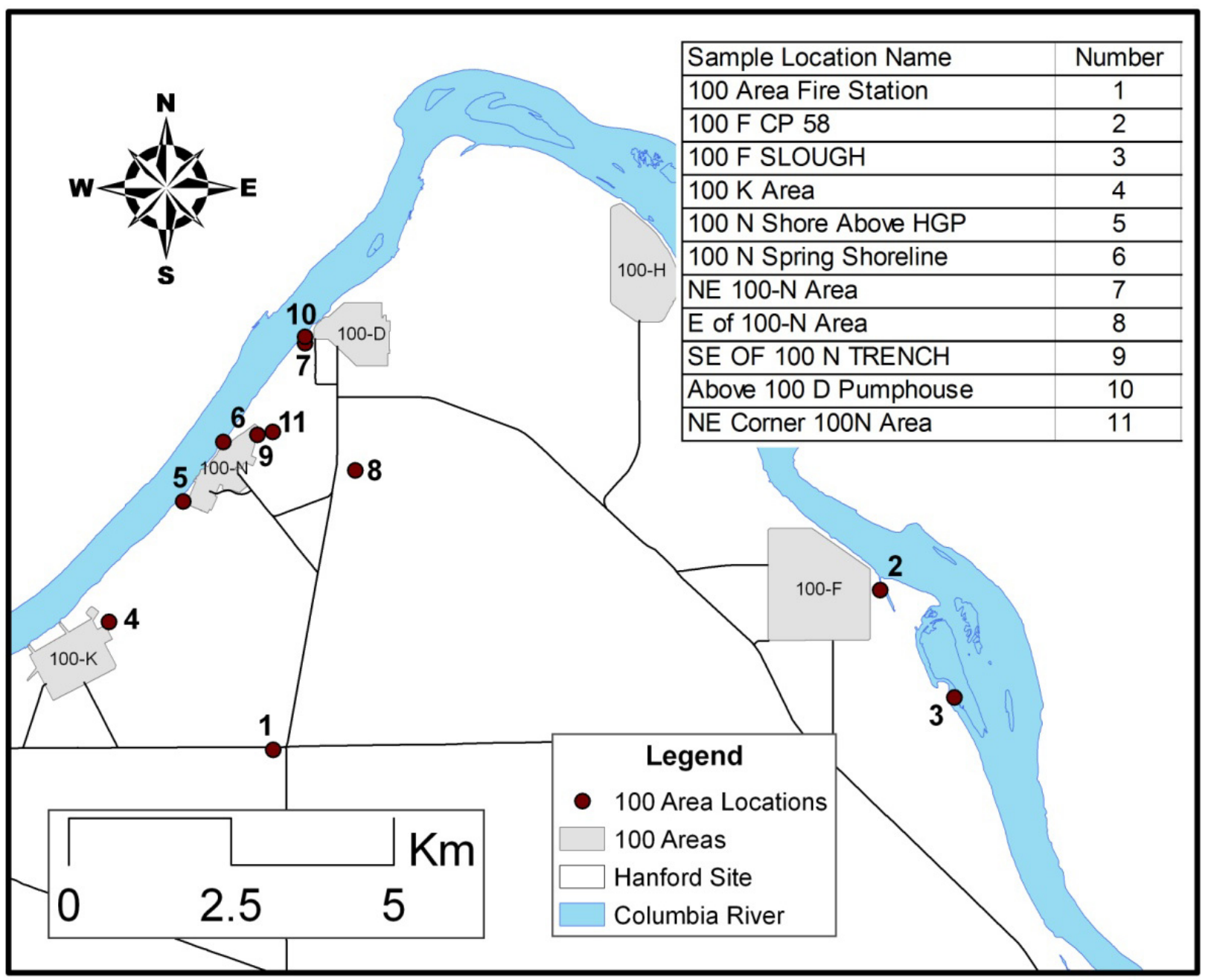

Figure A.2. Soil and Vegetation Sampling Sites Associated with the 100 Areas, Surveillance Monitoring from 1971 Through 2008 


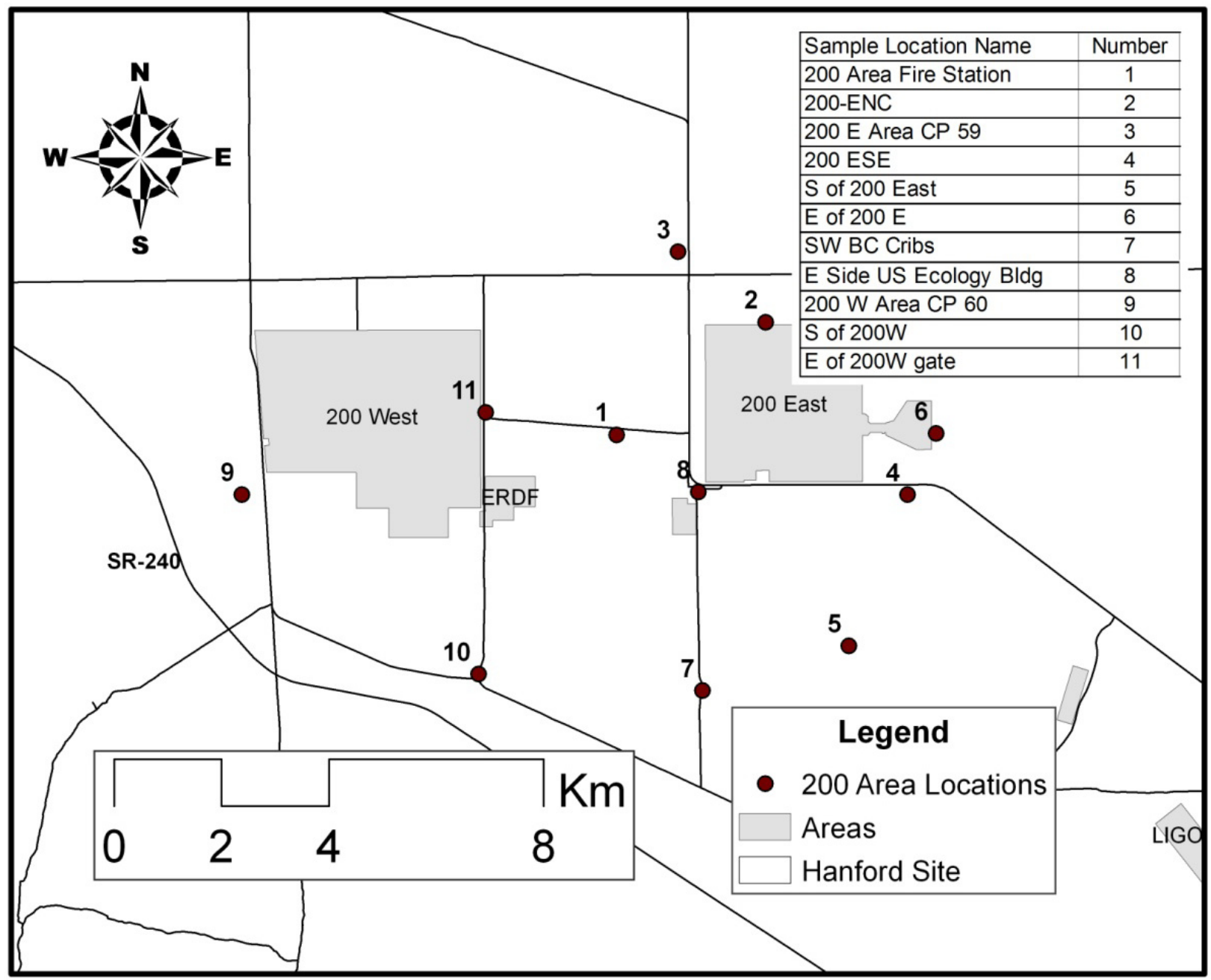

Figure A.3. Soil and Vegetation Sampling Sites Associated with the 200 Areas, Surveillance Monitoring from 1971 Through 2008 


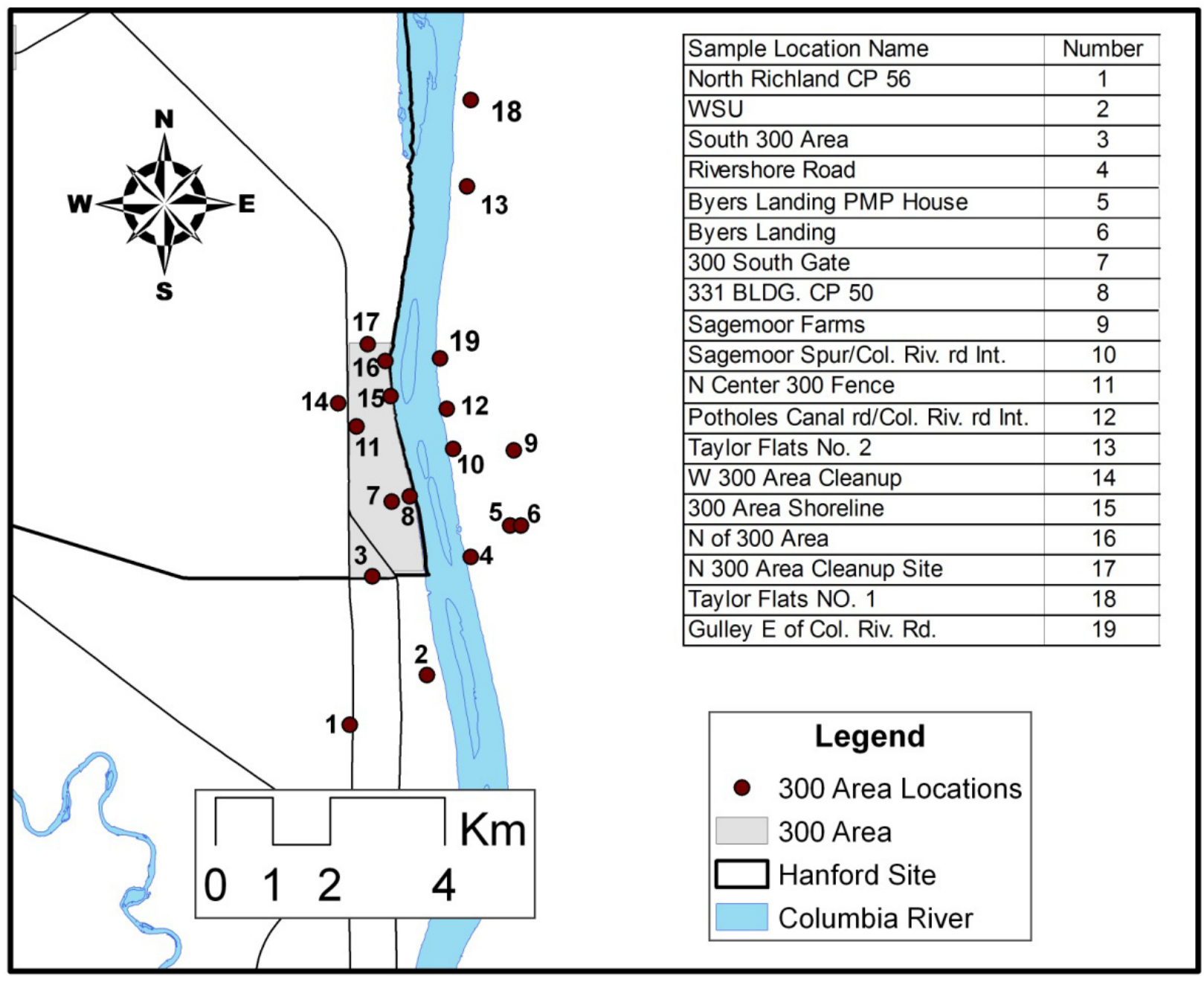

Figure A.4. Soil and Vegetation Sampling Sites Associated with the 300 Area and Perimeter Sampling Locations East of the 300 Area in Franklin County, 1971 Through 2008 


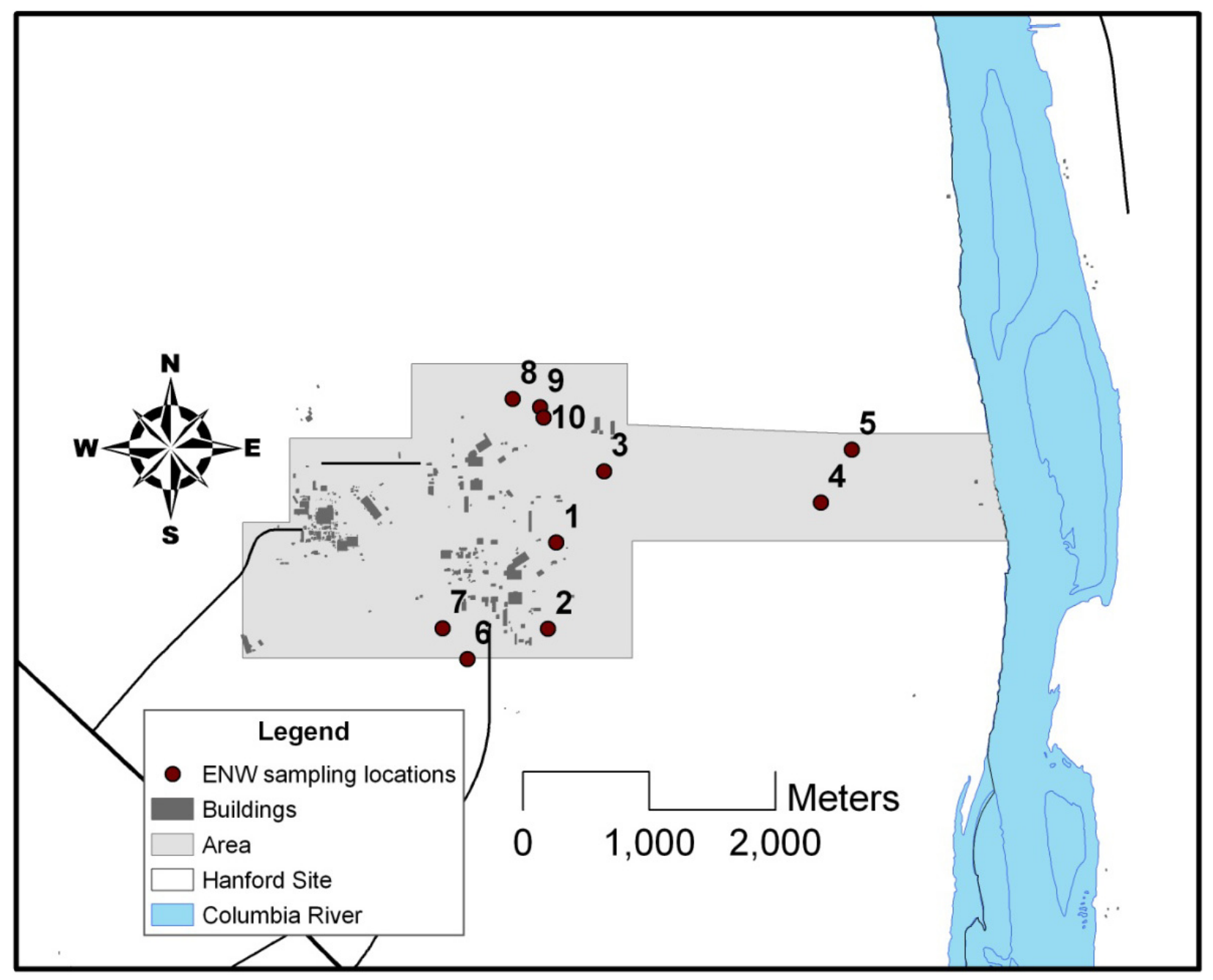

Figure A.5. Soil Sampling Sites on the Energy Northwest Site, Special Sampling Initiatives in 2002 


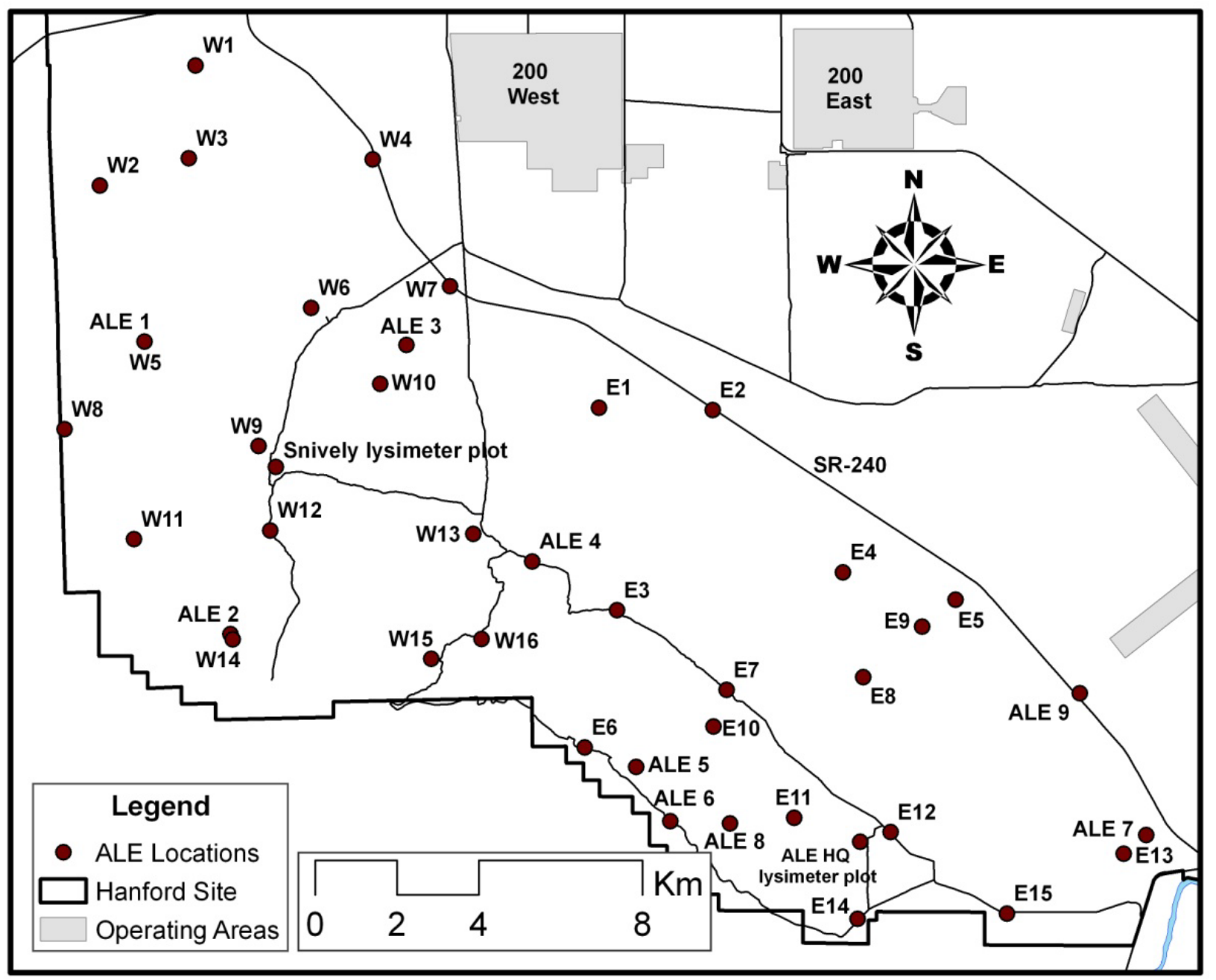

Figure A.6. Soil and Vegetation Sampling Sites on the Fitzner/Eberhardt Arid Lands Ecology Unit of the Hanford Reach National Monument, Special Sampling Initiatives 2006 


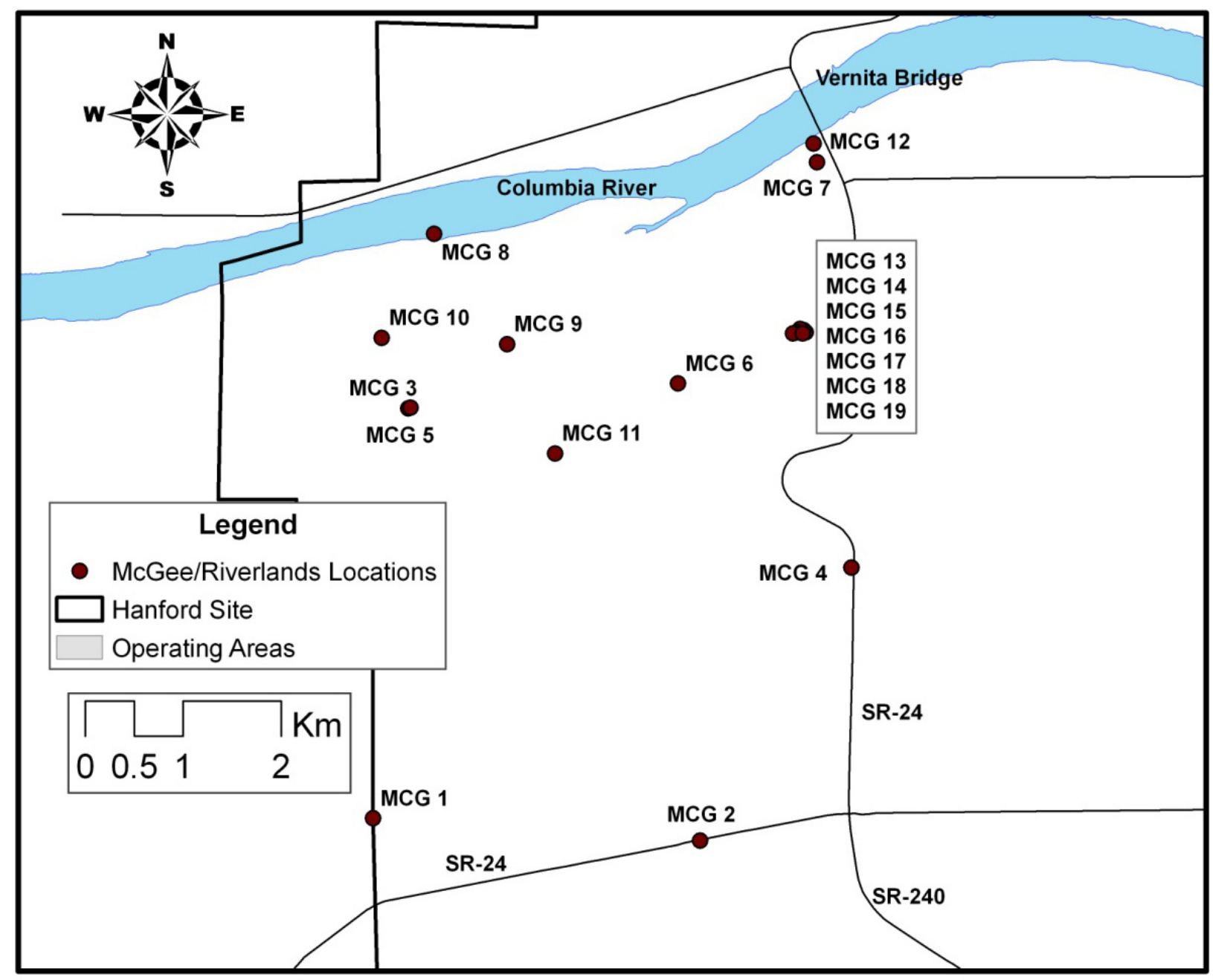

Figure A.7. Soil and Vegetation Sampling Sites on the McGee-Riverlands Unit of the Hanford Reach National Monument, Special Sampling Initiatives in 2006 


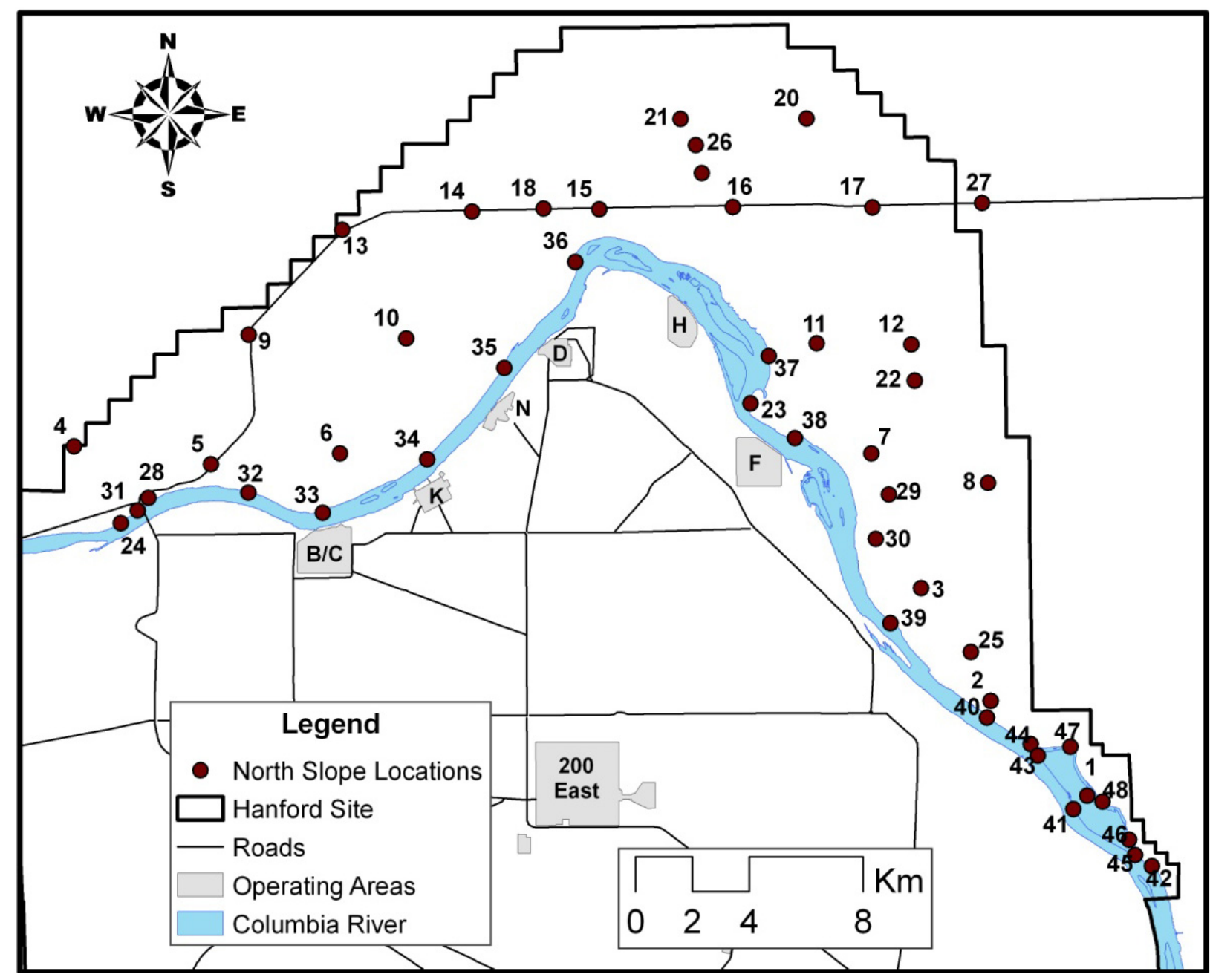

Figure A.8. Soil and Vegetation Sampling Sites on the North Slope on the Hanford Reach National Monument, Special Sampling Initiatives 2006 


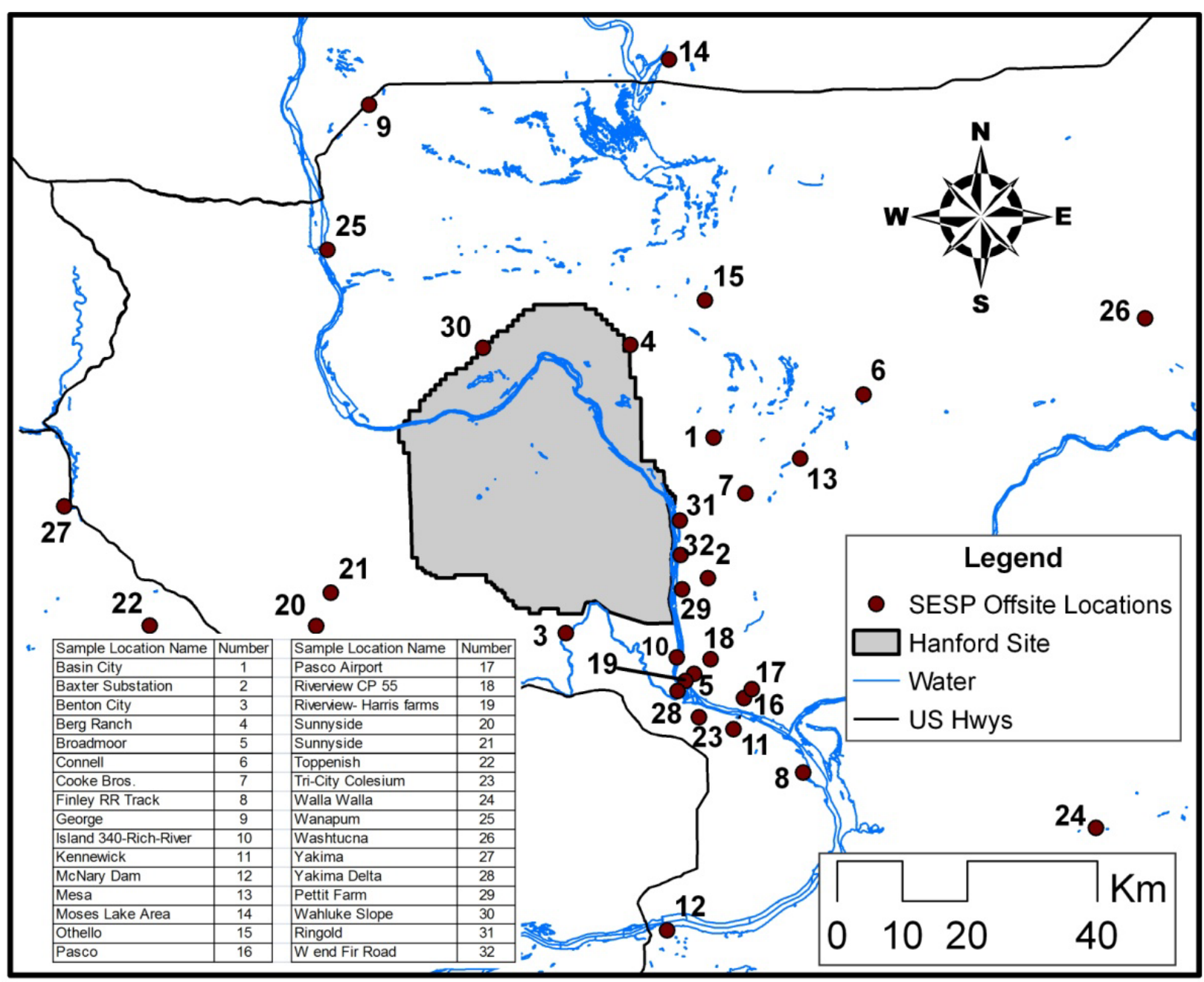

Figure A.9. Soil and Vegetation Sampling Sites Associated with Offsite Nearby and Distant Community Locations, Surveillance Monitoring from 1971 Through 2008 
Appendix B

Radionuclide Distributions in Soil and Vegetation Samples 



\section{Appendix B}

\section{Radionuclide Distributions in Soil and Vegetation Samples}

Box and whisker plots of radionuclide concentrations versus year show the distribution of the data and the interaction between year and area sampled (i.e., onsite versus offsite). Statistics depicted in the box and whisker plots are the median concentration, the range of the middle $50 \%$ of the data, and the nonoutlier range. A point is defined by Statistica ${ }^{1}$ to be an outlier if it meets the following criteria: 1) 75 th percentile $+1.5 *(75$ th -25 th percentile $)$ or 2$) 25$ th percentile $-1.5 *$ ( 75 th -25 th percentile). The non-outlier range is the range of values that fall between the 25 th or 75 th percentile and the outlier range.

\section{B.1 Cobalt-60}
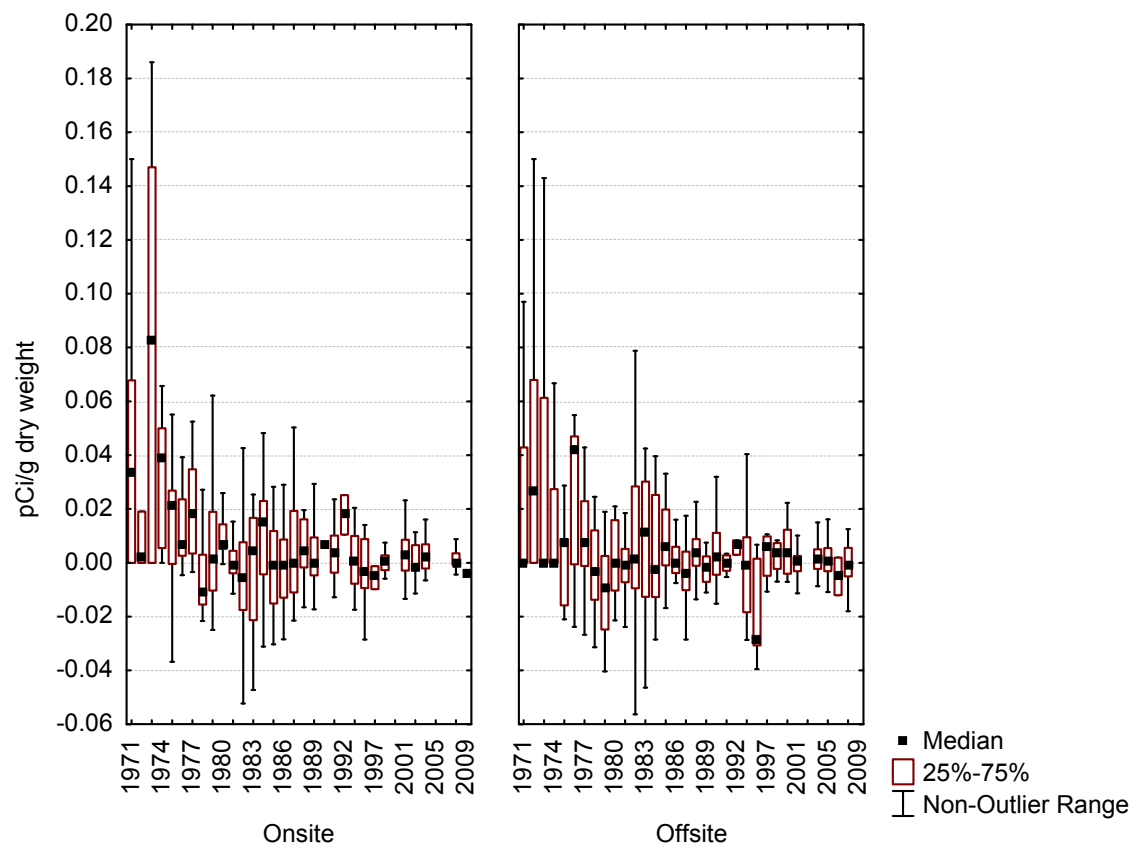

Figure B.1. Cobalt-60 Concentrations in Soil Samples Collected Between 1971 and 2008 On and Around the Hanford Site

\footnotetext{
${ }^{1}$ Statistica is a registered trademark of StatSoft, Inc., Tulsa, Oklahoma.
} 

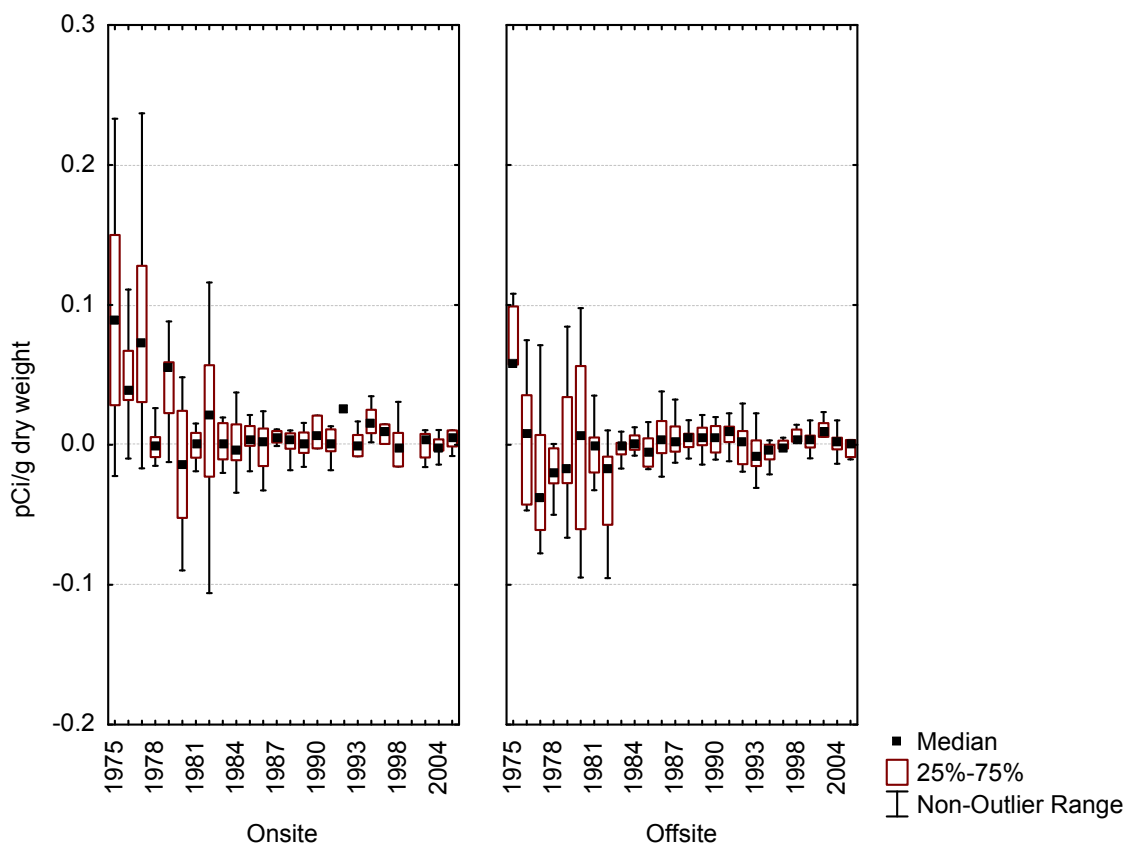

Figure B.2. Cobalt-60 Concentrations in Vegetation Samples Collected Between 1975 and 2008 On and Around the Hanford Site

\section{B.2 Cesium-137}
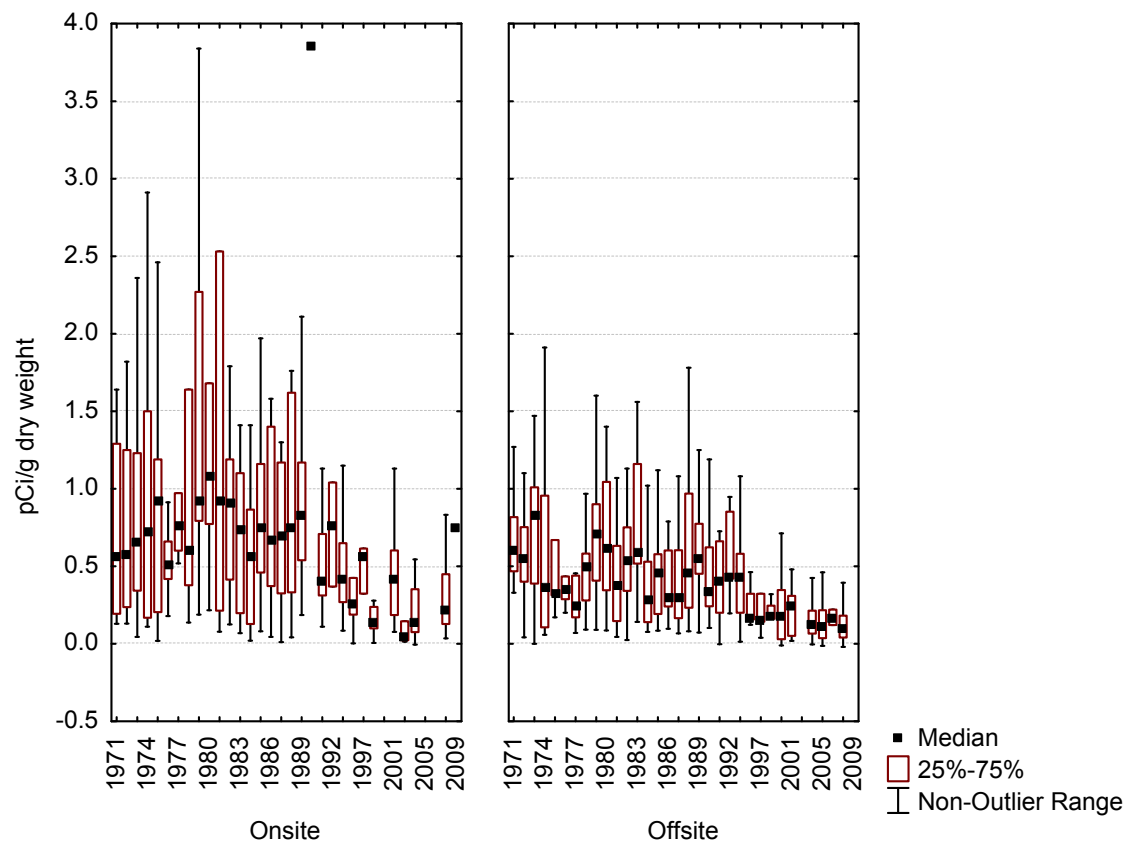

Figure B.3. Cesium-137 Concentrations in Soil Samples Collected Between 1971 and 2008 On and Around the Hanford Site 

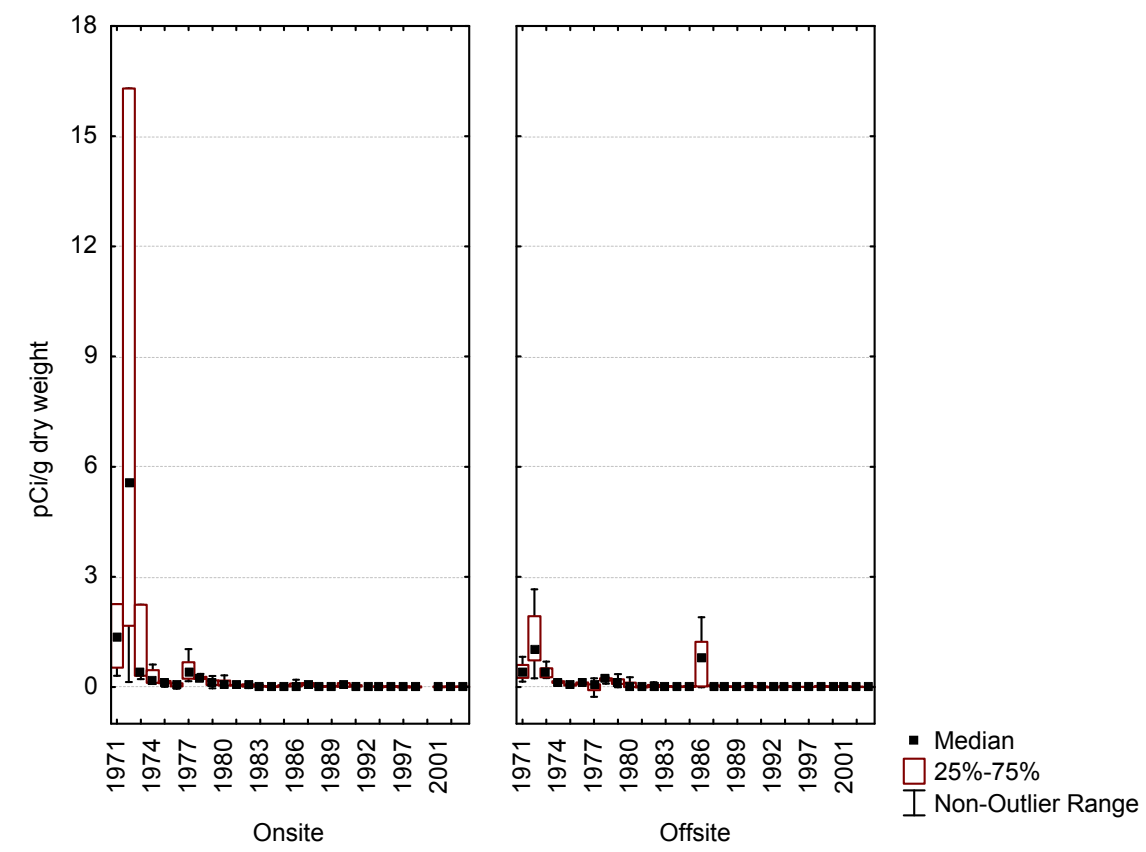

Figure B.4. Cesium-137 Concentrations in Vegetation Samples Collected Between 1971 and 2008 On and Around the Hanford Site

\section{B.3 Strontium-90}
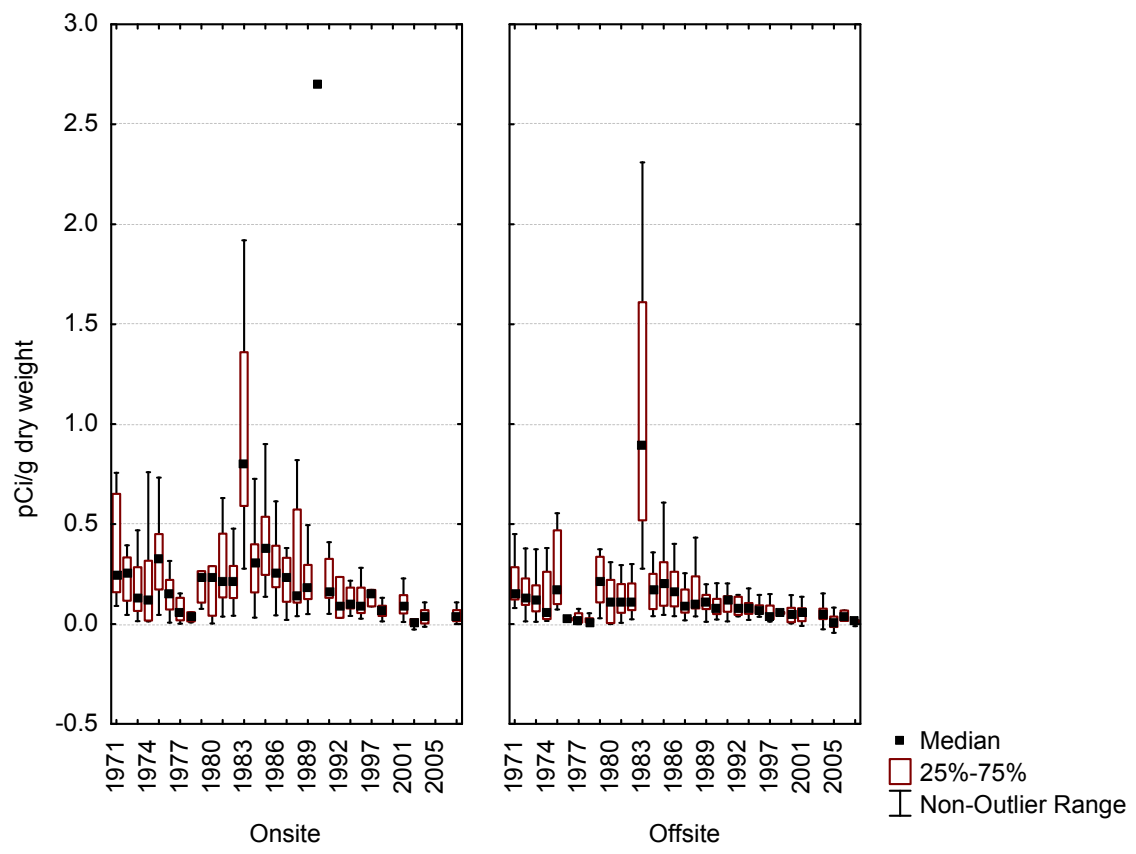

Figure B.5. Strontium-90 Concentrations in Soil Samples Collected Between 1971 and 2008 On and Around the Hanford Site 

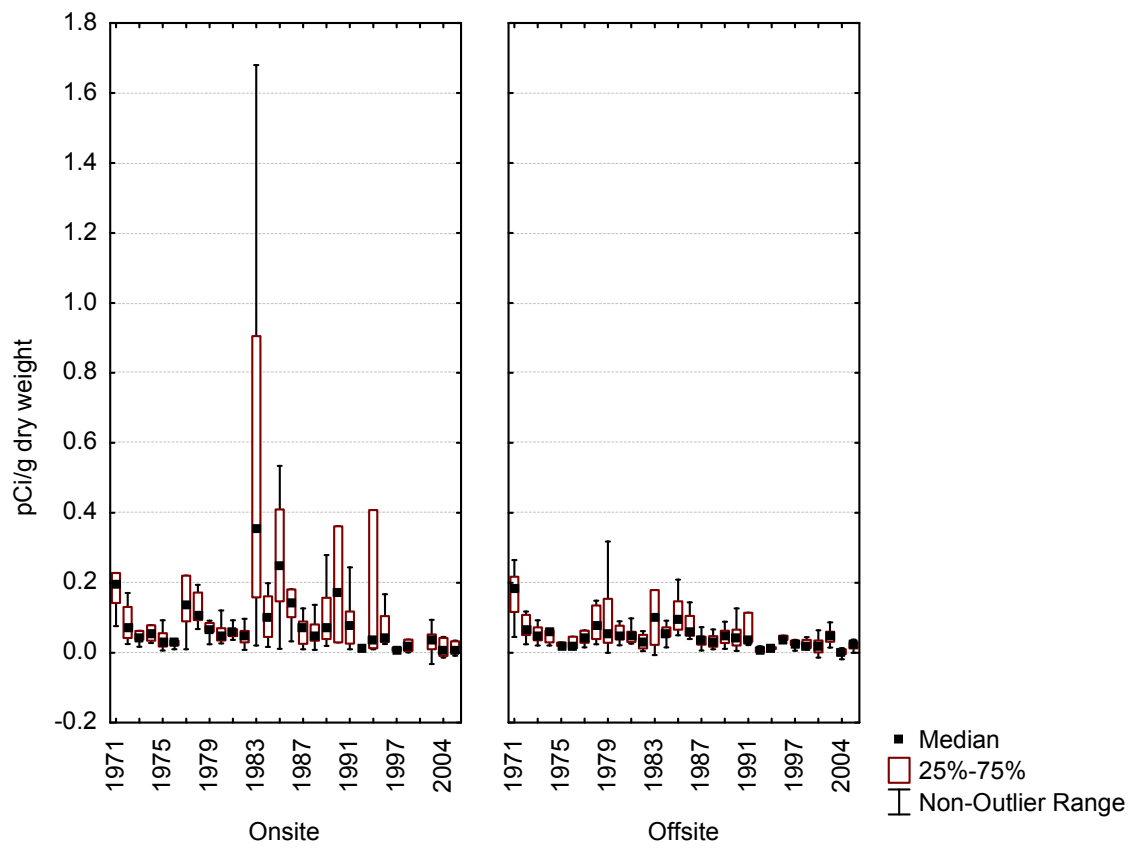

Figure B.6. Strontium-90 Concentrations in Vegetation Samples Collected Between 1971 and 2008 On and Around the Hanford Site

\section{B.4 Plutonium-238}

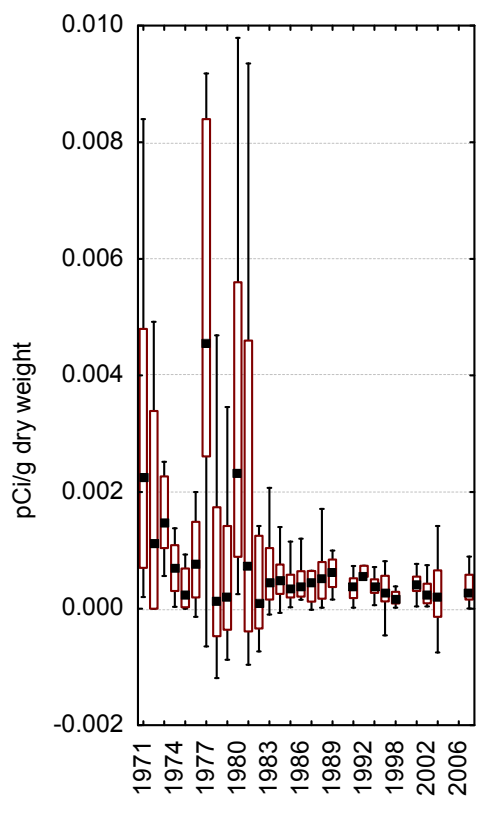

Onsite

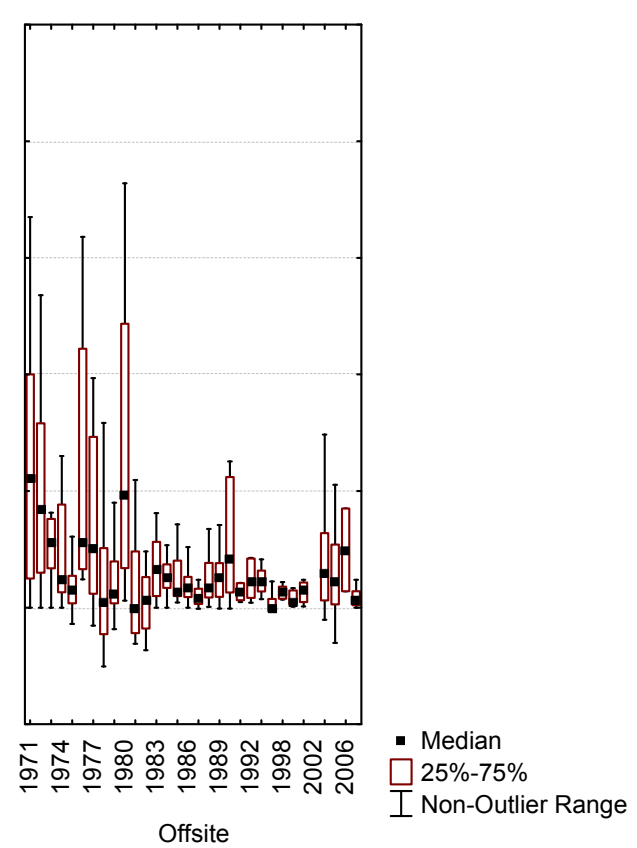

Figure B.7. Plutonium-238 Concentrations in Soil Samples Collected Between 1971 and 2008 On and Around the Hanford Site 

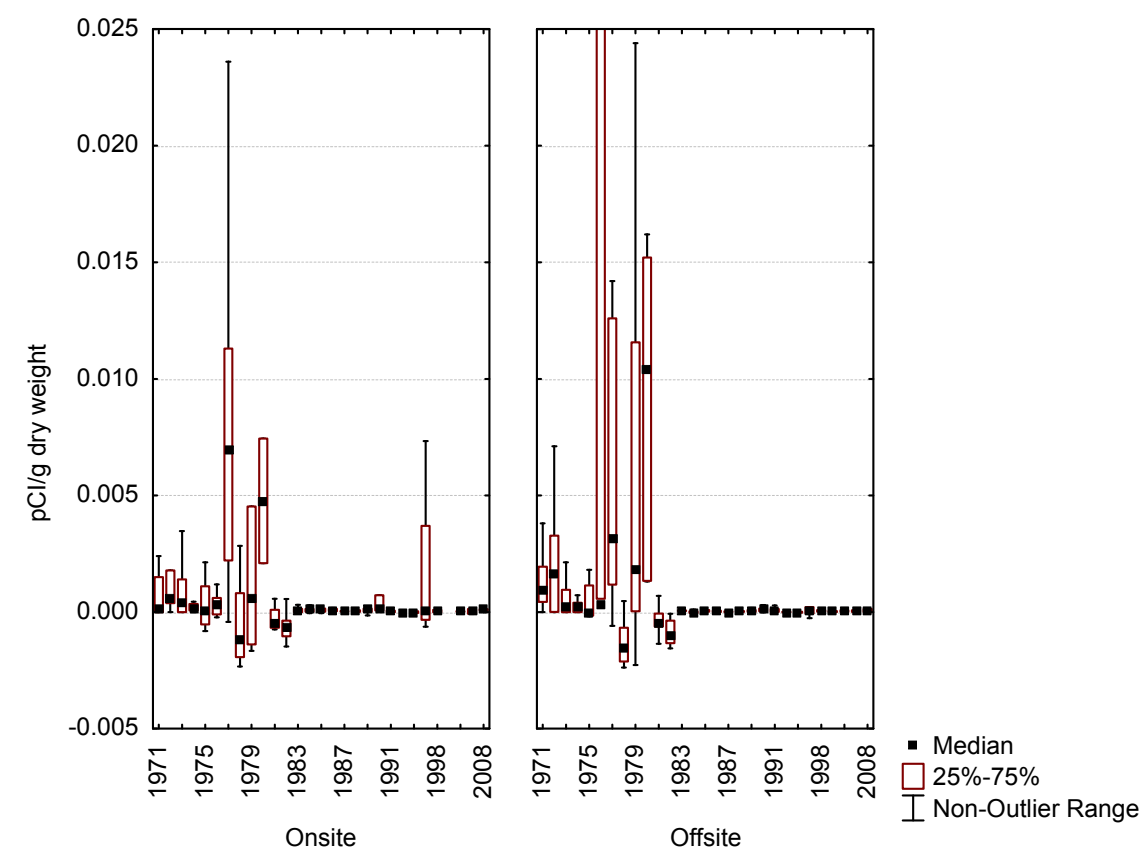

Figure B.8. Plutonium-238 Concentrations in Vegetation Samples Collected Between 1971 and 2008 On and Around the Hanford Site

\section{B.5 Plutonium-239/240}
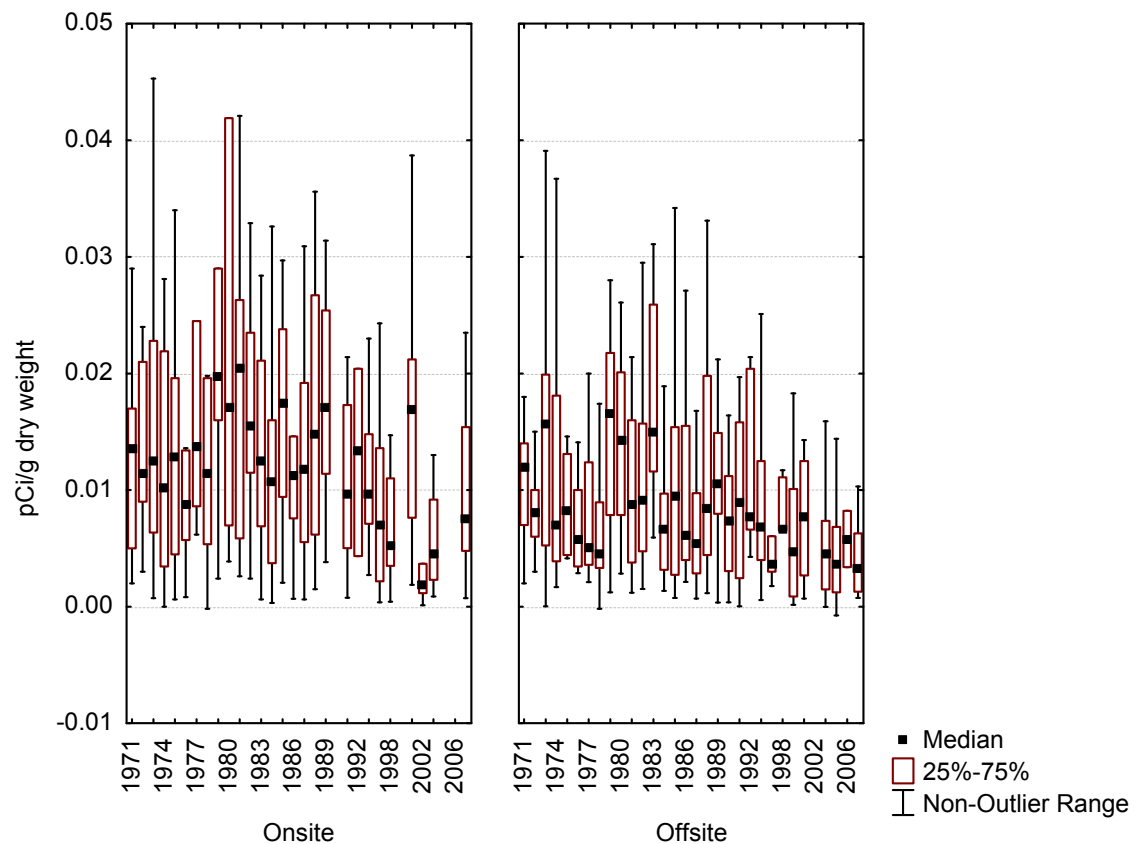

Figure B.9. Plutonium-239/240 Concentrations in Soil Samples Collected Between 1971 and 2008 On and Around the Hanford Site 

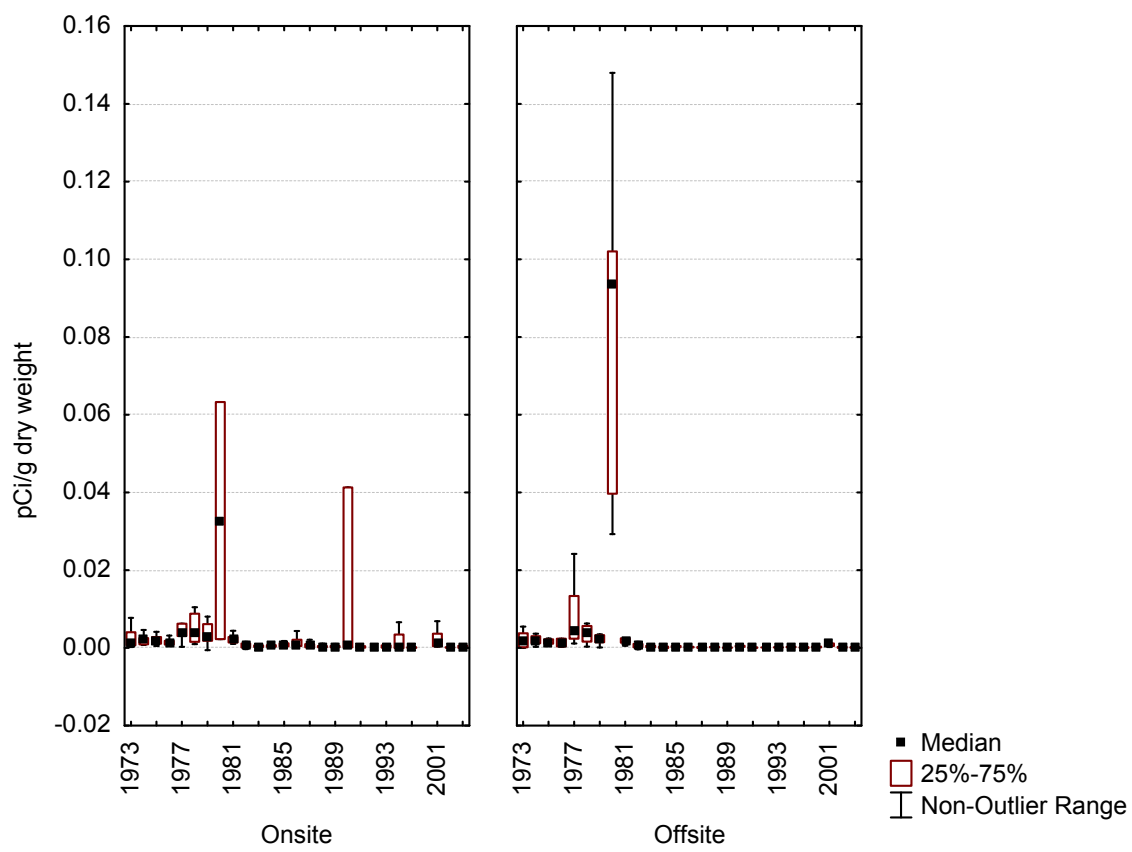

Figure B.10. Plutonium-239/240 Concentrations in Vegetation Samples Collected Between 1971 and 2008 On and Around the Hanford Site
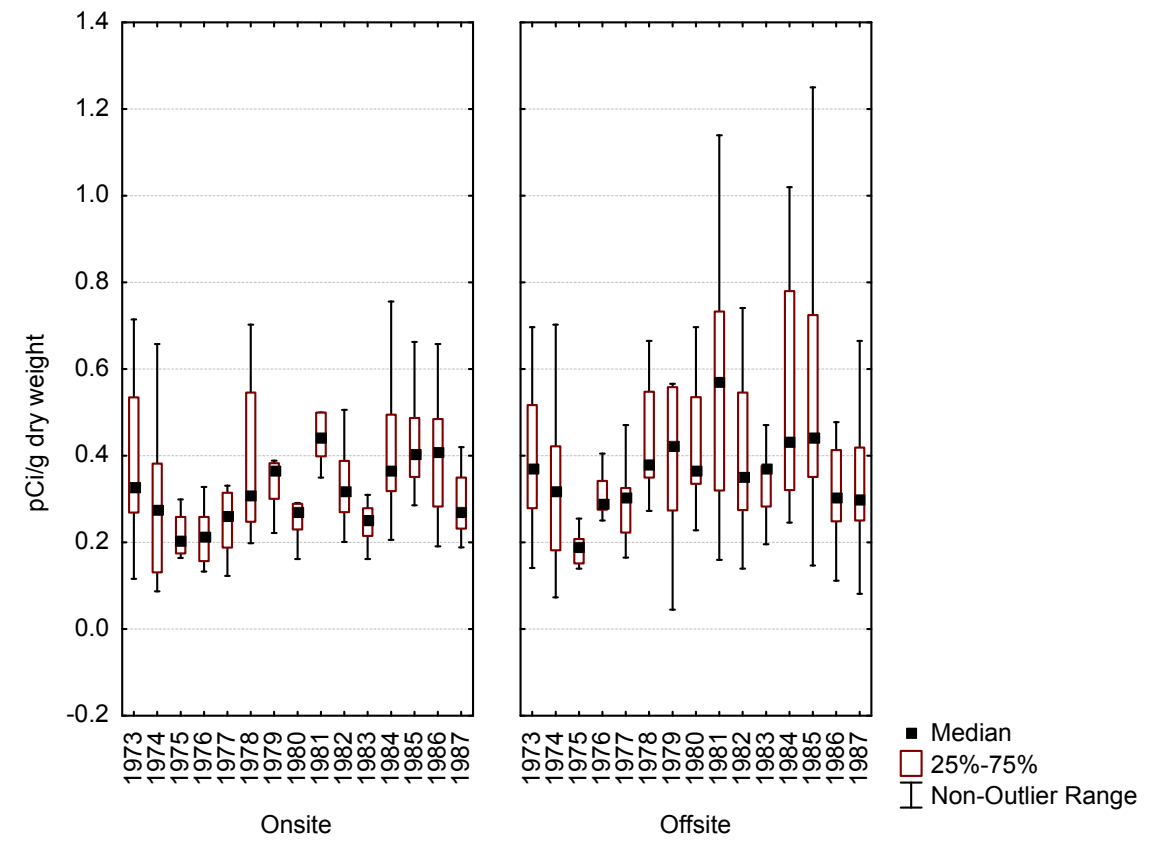

Figure B.11. Total Uranium Concentrations in Soil Samples Collected Between 1973 and 1987 On and Around the Hanford Site 

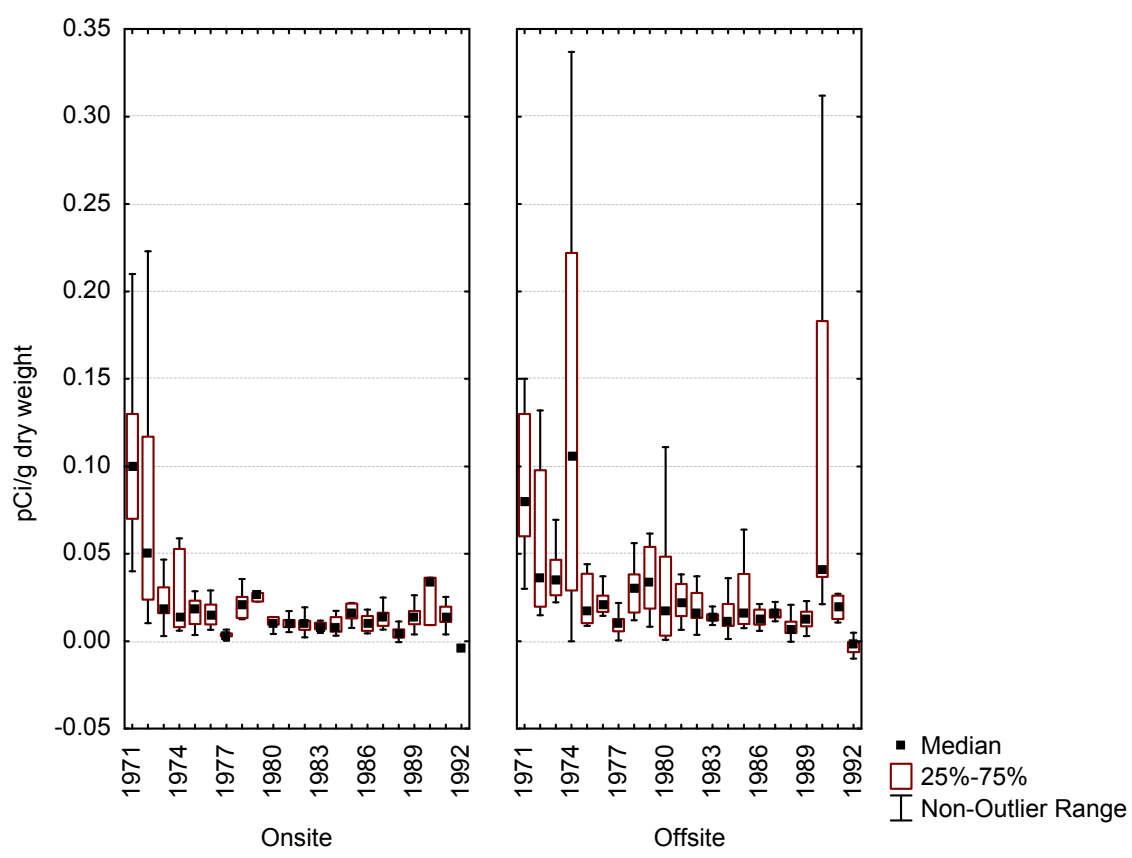

Figure B.12. Total Uranium Concentrations in Vegetation Samples Collected Between 1971 and 1992 On and Around the Hanford Site
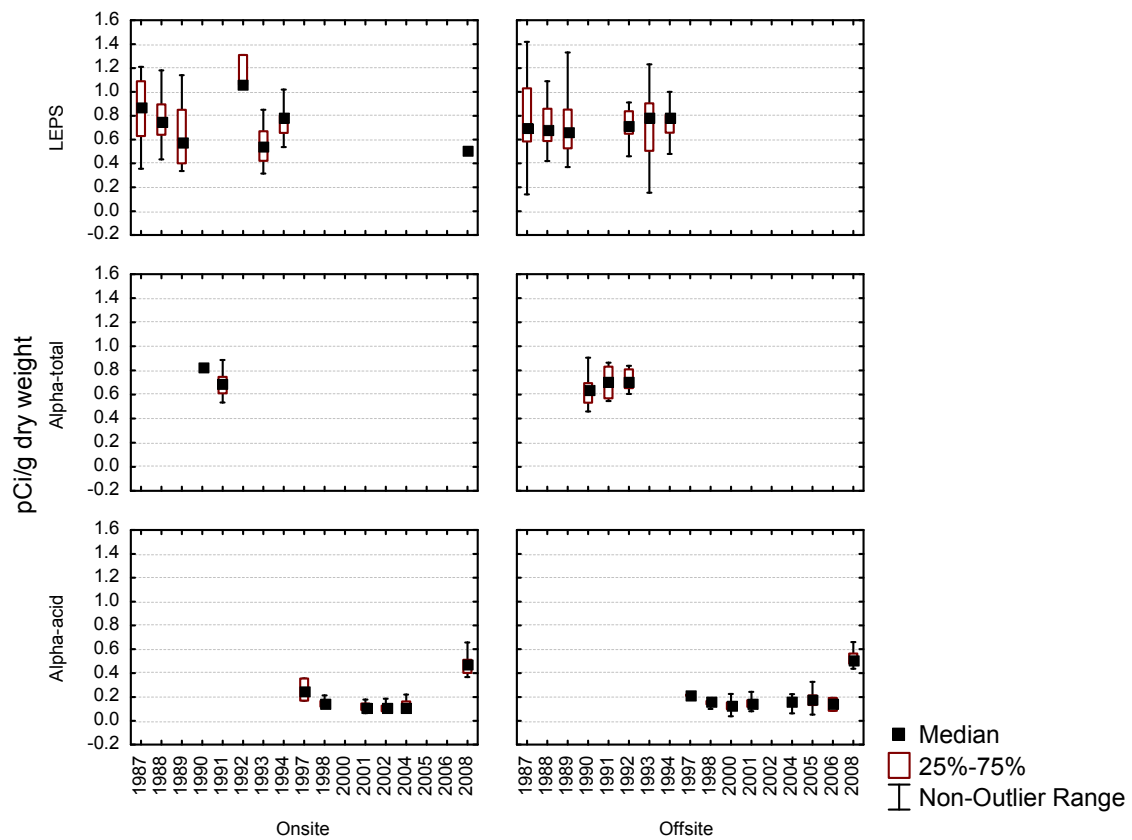

Figure B.13. Uranium-238 Concentrations in Soil Samples Collected Between 1987 and 2008 On and Around the Hanford Site. Samples analyzed using low-energy photon spectrometry (LEPS), alpha spectrometry with total dissolution (alpha-total) and alpha spectrometry with acid leaching (alpha-acid). 

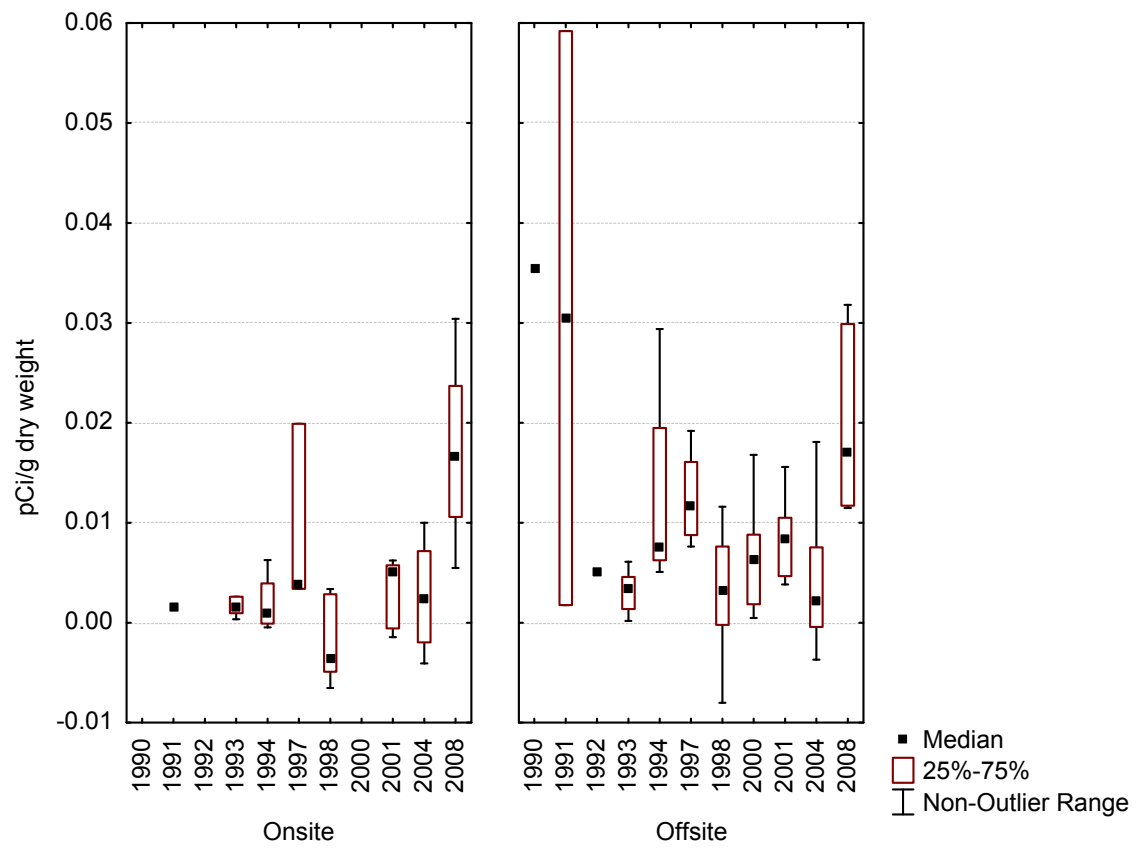

Figure B.14. Uranium-238 Concentrations in Vegetation Samples Collected Between 1990 and 2008 On and Around the Hanford Site 
Appendix C

Soil and Vegetation Temporal Trend Analysis 



\section{Appendix C}

\section{Soil and Vegetation Temporal Trend Analysis}

Temporal trends were evaluated using the Mann-Kendall test (Gilbert 1987; Helsel et al. 2006). The Mann-Kendall test was computed for onsite and offsite samples. Output from the test includes the correlation coefficient (Kendall's tau), the $P$-value for significance of the trend, and the slope of the overall trend. A computer program developed by the U.S. Geological Survey (USGS) was used to run the tests (Helsel et al. 2006). A $P$-value $<0.05$ was considered significant; negative slopes indicate the concentrations decreased over time, while positive slopes indicated an increase.

Onsite concentrations for all soil radionuclides except uranium-238 (LEPS) were significant (Table C.1) and except for uranium and uranium-238, the concentrations decreased over time. The lack of a negative trend for uranium and uranium-238 is probably due to the limited time period for data collection. Additionally, uranium was not dispersed by atmospheric process and that what was measured in most environments was natural background. Offsite results were similar to the onsite analysis.

Table C.1. Mann-Kendall Trend Results for Onsite and Offsite Radionuclides Concentrations Detected in Soil Samples

\begin{tabular}{lcccccc}
\hline & \multicolumn{3}{c}{ Onsite } & \multicolumn{3}{c}{ Offsite } \\
\cline { 2 - 6 } \multicolumn{1}{c}{ Radionuclide } & $\mathrm{p}$ & Correlation & Slope & $\mathrm{p}$ & Correlation & Slope \\
\hline Co-60 & $0.024^{(\mathrm{a})}$ & -0.088 & -0.0001 & 0.256 & -0.054 & 0 \\
$\mathrm{Cs}-137$ & $<0.001^{(\mathrm{a})}$ & -0.194 & -0.010 & $0.000^{(\mathrm{a})}$ & -0.308 & -0.0114 \\
$\mathrm{Sr}-90$ & $<0.001^{(\mathrm{a})}$ & -0.212 & -0.0045 & $0.000^{(\mathrm{a})}$ & -0.309 & -0.0039 \\
$\mathrm{Pu}-238$ & $0.042^{(\mathrm{a})}$ & -0.079 & -0.000003 & $0.022^{(\mathrm{a})}$ & -0.130 & -0.00005 \\
$\mathrm{Pu}-239 / 240$ & 0.075 & -0.069 & -0.00003 & $0.000^{(\mathrm{a})}$ & -0.189 & -0.00013 \\
$\mathrm{U}$ & $<0.001^{(\mathrm{a})}$ & 0.247 & 0.008 & 0.052 & 0.116 & 0.0035 \\
U-238 (LEPS) & 0.088 & -0.127 & 0 & 0.676 & 0.043 & 0 \\
U-238 (Alpha-acid) & $0.007^{(\mathrm{a})}$ & 0.241 & 0.001 & 0.075 & 0.316 & 0.0152 \\
\hline
\end{tabular}

(a) Significant at $\alpha=0.05$.

LEPS = Low-energy photon spectrometry.

There were fewer significant results for radionuclide concentrations in vegetation samples (Table C.2). In general, concentrations declined over time for all radionuclides except uranium-238 collected onsite and offsite, and cobalt-60 from offsite samples. 
Table C.2. Mann-Kendall Trend Results for Onsite and Offsite Radionuclide Concentrations Detected in Vegetation Samples

\begin{tabular}{lllllcr}
\hline & \multicolumn{3}{c}{ Onsite } & \multicolumn{3}{c}{ Offsite } \\
\cline { 2 - 7 } \multicolumn{1}{c}{ Radionuclide } & \multicolumn{1}{c}{$\mathrm{p}$} & Correlation & Slope & \multicolumn{1}{c}{$\mathrm{p}$} & Correlation & Slope \\
\hline Co-60 & 0.201 & -0.066 & $-1.11 \mathrm{E}-04$ & $0.0001^{(\mathrm{a})}$ & 0.236 & $8.18 \mathrm{E}-04$ \\
Cs-137 & $0.000^{(\mathrm{a})}$ & -0.370 & $-6.24 \mathrm{E}-03$ & $0.000^{(\mathrm{a})}$ & -0.285 & $-1.48 \mathrm{E}-03$ \\
$\mathrm{Sr}-90$ & 0.074 & -0.093 & $-6.69 \mathrm{E}-04$ & $0.000^{(\mathrm{a})}$ & -0.275 & $-1.35 \mathrm{E}-03$ \\
$\mathrm{Pu}-238$ & 0.211 & -0.067 & $-5.78 \mathrm{E}-07$ & 0.956 & -0.004 & $0.00 \mathrm{E}+00$ \\
$\mathrm{Pu}-239 / 240$ & $0.000^{(\mathrm{a})}$ & -0.399 & $-9.22 \mathrm{E}-05$ & $0.000^{(\mathrm{a})}$ & -0.379 & $-4.48 \mathrm{E}-05$ \\
$\mathrm{U}$ & 0.195 & -0.069 & $-6.00 \mathrm{E}-05$ & $0.000^{(\mathrm{a})}$ & -0.232 & $-8.17 \mathrm{E}-04$ \\
$\mathrm{U}-238$ & $0.005^{(\mathrm{a})}$ & 0.313 & $3.79 \mathrm{E}-04$ & 0.143 & 0.173 & $1.30 \mathrm{E}-04$ \\
\hline
\end{tabular}

(a) Significant at $\alpha=0.05$.

\section{References}

Gilbert RO. 1987. Statistical Methods for Environmental Pollution Monitoring. Van Nostrand Reinhold Company, New York.

Helsel DR, DK Mueller, and JR Slack. 2006. Computer Program for the Kendall Family of Trend Tests. Scientific Investigations Report 2005-5275, U.S. Geological Survey. Available at http://pubs.usgs.gov/sir/2005/5275/ (July 2011). 


\section{Distribution}

No. of

Copies

\section{OFFSITE}

L Albright

U.S. Fish and Wildlife Service

64 Maple Street

Burbank, WA 99323

C Andrade

National Oceanic and Atmospheric

Administration

DARC 7600

Sandpoint Way NE

Seattle, WA 98115

J Bartoszek

U.S. Fish and Wildlife Service

64 Maple Street

Burbank, WA 99323

G Bohnee

Nez Perce Tribe

P.O. Box 365

Lapwai, ID 83540

L Buck

Wanapum

P.O. Box 878

Ephrata, WA 98823

R Buck, Jr.

Wanapum

P.O. Box 878

Ephrata, WA 98823

L Buelow

U.S. Environmental Protection Agency

309 Bradley Boulevard

Suite 115, MS B1-46

Richland, WA 99352

L Gadbois

U.S. Environmental Protection Agency

309 Bradley Boulevard

Suite 115, MS B1-46

Richland, WA 99352
No. of

$\underline{\text { Copies }}$
L Goldstein

Washington State Department of Ecology

P.O. Box 47600

Olympia, WA 98504

B Harper

Confederated Tribes of the Umatilla Indian

Reservation

750 Swift, Suite 14

Richland, WA 99352

S Harris

Confederated Tribes of the Umatilla Indian

Reservation

P.O. Box 638

Pendleton, OR 97801

D Landeen

Hanford Natural Resources Trustee Council

Nez Perce Tribe

P.O. Box 365

Lapwai, ID 83540

M Livingston

Washington Department of Fish and

Wildlife

2620 N. Commercial Avenue

Pasco, WA 99301

J McConnaughey

Yakama Nation

P.O. Box 6066

Kennewick, WA 99336-0066

H Newsome

Hanford Reach National Monument

U.S. Fish and Wildlife Service

64 Maple Street

Burbank, WA 99323

A Nomee

Department of Natural Resources

Coeur d'Alene Tribe

P.O. Box 408

Plummer, ID 83851-9703

Distr.1 
No. of

Copies

J Price

Washington State Department of Ecology

3100 Port of Benton Boulevard

Richland, WA 99354

M Priddy

Washington State Department of Health

309 Bradley Boulevard

Suite 201

Richland, WA 99352

P Rigdon

Yakama Nation

P.O. Box 151

Toppenish, WA 98948

P Shaffer

Oregon Department of Energy

625 Marion Street NE

Salem, OR 97301-3737

J Skriletz

Washington Department of Fish and

Wildlife

600 Capitol Way

1111 Washington Street NE

Olympia, WA 98501-1091

JA Strand

College of Science, Environmental Science

CIC 102B

WSU Tri-Cities

2710 University Drive

Richland, WA 99354-1671

BL Tiller

P.O. Box 265

Richland, WA 99352
No. of

\section{Copies}

DOE Pacific Northwest Site Office

J Erickson K9-42

4 DOE Richland Operations Office

AR Hawkins A5-14

KM Thompson A6-38

DC Ward A5-15

SR Weil A5-15

2 Mission Support Alliance, LLC

AR Johnson R3-12

DD Teel H7-28

2 Washington Closure Hanford, LLC

D Jacques

H4-22

LC Hulstrom

H4-22

13 Pacific Northwest National Laboratory

JM Becker K6-85

RL Dirkes K6-75

JL Downs K6-85

RE Durham K6-85

DR Geist K6-85

KD Hand K6-85

KB Larson K6-85

RP Mueller K6-85

TM Poston K6-75

MR Sackschewsky K6-85

MA Simmons K6-85

JA Stegan K3-66

Historical File - TM Poston K6-75

\section{ONSITE}

2 DOE Office of River Protection

$\begin{array}{ll}\text { LA Huffman } & \text { H6-60 } \\ \text { W Russell } & \text { H6-60 }\end{array}$ 



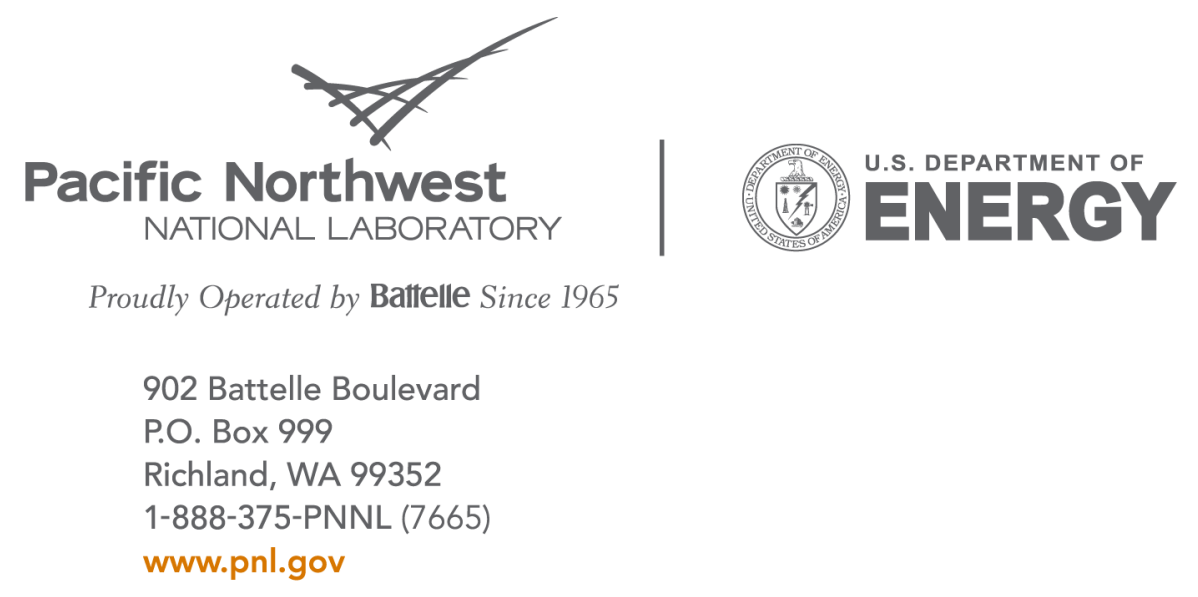

